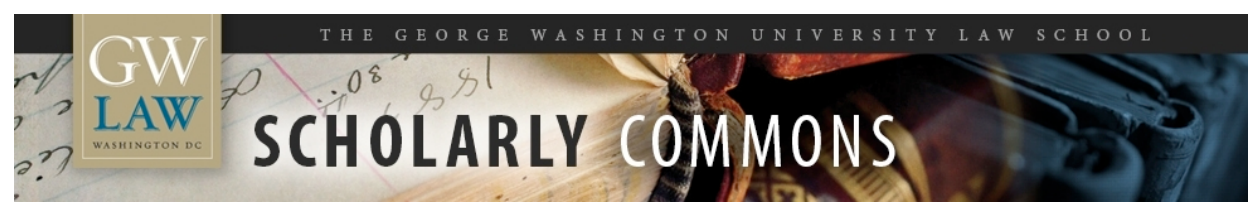

GW Law Faculty Publications \& Other Works

Faculty Scholarship

2020

\title{
The Trans Panic Defense Revisited
}

Cynthia Lee

George Washington University Law School, cylee@law.gwu.edu

Follow this and additional works at: https://scholarship.law.gwu.edu/faculty_publications

Part of the Law Commons

\section{Recommended Citation}

Lee, Cynthia, The Trans Panic Defense Revisited (2019). 57 AM. CRIM. L. REV. 1411 (2020); GWU Law School Public Law Research Paper No. 2019-63; GWU Legal Studies Research Paper No. 2019-63. Available at SSRN: https://ssrn.com/abstract $=3481295$

This Article is brought to you for free and open access by the Faculty Scholarship at Scholarly Commons. It has been accepted for inclusion in GW Law Faculty Publications \& Other Works by an authorized administrator of Scholarly Commons. For more information, please contact spagel@law.gwu.edu. 


\title{
ARTICLES
}

\section{THE TRANS PANIC DEFENSE REVISITED}

\section{Cynthia Lee*}

\begin{abstract}
Violence against transgender individuals in general, and trans women of color in particular, is a significant problem in the United States today. When a man is charged with murdering a transgender woman, a common defense strategy is to assert what is called the trans panic defense. The trans panic defense is not a traditional criminal law defense. Nor, despite its name, is it recognized as a standalone defense. Rather, trans panic is a defense strategy associated with the provocation or heat of passion defense. A murder defendant asserting trans panic will claim that the discovery that the victim was a transgender female-an individual who identifies as a woman but was thought to be male when born-provoked him into a heat of passion, causing him to lose his self-control. If the jury finds that the defendant was actually provoked into a heat of passion and that the ordinary man in the defendant's shoes would have been so provoked, it can acquit him of murder and find him guilty of a lesser offense.

This Article starts by discussing the problem of violence against transgender individuals in the United States today. It then focuses upon a particular manifestation of this violence-cases in which a man kills a transgender woman with whom he was intimate or to whom he was attracted, is arrested and charged with a criminal homicide, and then asserts a trans panic defense.
\end{abstract}

\footnotetext{
* Cynthia Lee is the Edward F. Howrey Professor of Law at The George Washington University Law School. She thanks I. Bennett Capers, Em Holmes, Hunter Iannucci, Kelly Strader, and Jordan Blair Woods for reading and providing extremely helpful suggestions on an earlier draft of this Article. She also thanks her colleagues Jeremey Bearer-Friend, Robert Cottrol, Alan Morrison, Anne Olesen, Dick Pierce, Steve Saltzburg, Peter Smith, Ed Swaine, and Kate Weisburd for their questions, comments, and suggestions when she presented this Article before the GW Law faculty on September 6, 2019. She thanks Nancy Cantalupo, Eve Hanan, and Alexis Karteron for providing additional helpful feedback when she presented this Article at LatCrit on October 18, 2019 at Georgia State University College of Law in Atlanta, Georgia. She also thanks her current and former Research Assistants Lisa Haight, Stephanie Hansen, Casey Matsumoto, and Katherine Yue Meng for excellent research assistance, Lesliediana Jones for additional research assistance, and Prerna Balasundarum for administrative assistance on this Article. Finally, she thanks the American Criminal Law Review at Georgetown University Law Center for inviting her to participate in its symposium on women and the criminal justice system in March 2019. Special thanks to Monica Attia, Abbe Dembowitz, Ian Bruckner, and Julie Bessler from the American Criminal Law Review for their editorial assistance and support for the ideas expressed within. Parts of this Article are adapted from Cynthia Lee \& Peter Kwan, The Trans Panic Defense: Masculinity, Heteronormativity, and the Murder of Transgender Women, 66 HASTINGS L.J. 77 (2014) and Cynthia Lee, The Gay Panic Defense, 42 U.C. Davis L. Rev. 471 (2008). (C) 2020, Cynthia Lee.
} 
Next, this Article offers several reasons why the trans panic defense strategy is deeply problematic. First, the trans panic defense appeals to negative stereotypes about transgender individuals. Second, it legitimizes the enforcement of norms of masculinity and heterosexuality through violence. Third, it inappropriately validates bias against transgender individuals when we live in a pluralistic society that should be tolerant and accepting of all individuals.

The Article then addresses the normative question of what should be done to rectify the harms rendered when a defendant charged with murder asserts a trans panic defense. In the past, the Author was reluctant to support proposals to legislatively ban the trans panic defense. She felt that the best way to defeat the trans panic defense was not to ban it, but to allow it to be aired and then have a strong prosecutor explain to the jury why it should be rejected. She also argued that it was critically important to eradicate the underlying structures of masculinity that encourage violence against transgender women to reduce the risk of such violence taking place and to undermine the effectiveness of the trans panic defense. She opined that the best way to achieve these goals was to educate both the public and the jury about the difficulties transgender individuals face just trying to exist in society and make the existence of bias against transgender individuals salient to the jury.

While the Author still believes in the importance of education, she now feels education alone is insufficient to ensure that juries reject the trans panic defense. The Article explains the Author's shift in position and concludes by examining recently enacted legislative bans on the trans panic defense and offering concrete suggestions on how legislative reform in this arena could be strengthened.

\section{INTRODUCTION}

On August 17, 2013, James Dixon was walking on Frederick Douglass Boulevard in Harlem with some friends when he spotted Islan Nettles, an attractive transgender woman. ${ }^{1}$ Dixon crossed the street and began chatting with Nettles, asking her for her name and where she was from. ${ }^{2}$ Soon he heard his friends

1. James C. McKinley, Jr., Man's Confession in Transgender Woman's Death is Admissible, Judge Rules, N.Y. TIMES (Apr. 2, 2018), https://www.nytimes.com/2016/04/02/nyregion/mans-confession-in-transgender-womansdeath-is-admissible-judge-rules.html [https://perma.cc/KJF6-8QRB]; James C. McKinley Jr., Manslaughter Charges in Beating Death of Transgender Woman in 2013, N.Y. TIMES (Mar. 3, 2015), https://www.nytimes.com/ 2015/03/04/nyregion/manslaughter-charges-in-beating-death-of-transgender-woman-in-2013.html?module=inline [https://perma.cc/946R-NY5X]; Kenrya Rankin, James Dixon to Serve 12 Years for Killing Islan Nettles, COLORLINES (Apr. 20, 2016), https://www.colorlines.com/articles/james-dixon-serve-12-years-killing-islannettles [https://perma.cc/WX3G-U4TF].

2. Yanan Wang, The Islan Nettles Killing: What the Trial Means to a Transgender Community Anxious for a Reckoning, WASH. POST (Apr. 4, 2016), https://www.washingtonpost.com/news/morning-mix/wp/2016/04/04/ the-islan-nettles-killing-what-the-trial-means-to-a-transgender-community-anxious-for-a-reckoning/?utm_term= $.4022685 \mathrm{c} 4 \mathrm{e} 96$ [https://perma.cc/74TB-S3BZ]. 
mocking him for flirting with Nettles, saying, "that's a guy."3 Dixon's demeanor suddenly changed. Angrily, Dixon demanded to know if Nettles "was a man" before punching and knocking her to the ground. ${ }^{4}$ Dixon's attack "left the 21-yearold African American comatose, her face battered beyond recognition." ${ }^{5}$ Nettles died five days later from head injuries she suffered after hitting the concrete. ${ }^{6}$

Initially, Dixon admitted that he was the person who had attacked Nettles. ${ }^{7}$ In explaining why he punched Nettles, Dixon told police, "I just didn't want to be fooled," suggesting that Nettles' misrepresentation of her sex had provoked him. ${ }^{8}$ His explanation echoes a familiar theme of trans panic that suggests that by holding herself out as female, the transgender woman culpably tries to trick straight men into having sex with her. It reinforces the trope of the transgender female as a deceitful interloper, trying to pass as female in order to capture unwitting heterosexual men. Dixon's comments also suggested Nettles was at fault for her own death, even though Dixon was the one who initiated the conversation, and it appears that she did nothing to provoke the attack except for being a transgender woman. ${ }^{9}$

After he was arrested, Dixon changed his story and told the media he was not the person responsible for Nettles' death, saying, "I'm really sorry for the family's loss, but they got the wrong guy. . . . I didn't kill anyone." ${ }^{10} \mathrm{He}$ also stated, "I can tell the difference between a man and a woman. . . . I don't have anything against gay people or transgender people. . . I don't just go pick fights with random people I don't know. That's not me."11

In March 2015, Dixon was charged with first-degree manslaughter. ${ }^{12}$ Initially, he pleaded not guilty to all the charges, intending to go to trial. ${ }^{13}$ Later, Dixon pled guilty to second-degree manslaughter and first-degree assault. ${ }^{14} \mathrm{He}$ was sentenced to twelve years in prison. ${ }^{15}$

3. Id.

4. Rankin, supra note 1.

5. Wang, supra note 2.

6. Rankin, supra note 1.

7. Wang, supra note 2.

8. See Shayna Jacobs, Murder Suspect Said His 'Manhood' Was Threatened When He Found Out He Was Hitting on Transgender Woman, N.Y. DAILY NEws (Apr. 1, 2016), https://www.nydailynews.com/new-york/nyccrime/transgender-slay-suspect-manhood-threatened-article-1.2585915 [https://perma.cc/4J7H-TJBB] (quoting Dixon's confession to the police).

9. According to her friends and family, Nettles had just started being open about her transgender identity before she was killed. Wang, supra note 2. Her death was particularly tragic because after years of living in poverty, Nettles had finally gotten a job in retail, was starting her own fashion line, and had moved into her own apartment. Id.

10. Wang, supra note 2.

11. Id.

12. Id.

13. Id.

14. Rankin, supra note 1.

15. Id. 
The underlying impetus for Dixon's loss of self-control seems to have been Dixon's fear of being seen as gay. ${ }^{16}$ Recall that just before he attacked Nettles, Dixon heard his friends mocking him for hitting on a guy. Dixon's friends obviously considered Nettles, a transgender woman, to be a man. By attacking Nettles, Dixon could demonstrate that he was not attracted to her-at least not once he realized that she was a transgender female. Dixon may have felt it especially important to prove that he was not attracted to Nettles because just a few days earlier, he had hit on two other transgender women, and his friends had mocked him for doing so. ${ }^{17}$

Violence against transgender individuals_-particularly transgender women of color-is a significant problem today. ${ }^{18}$ In 2018 , at least twenty-six transgender individuals were killed in the United States. ${ }^{19}$ This statistic suggests that two or more transgender individuals were killed each month. The vast majority-twentyfive of these twenty-six homicide victims (96\%)-were transgender women. ${ }^{20}$ Twenty-three of the twenty-six transgender homicide victims in 2018 (approximately 85\%) were trans women of color. ${ }^{21}$ The actual number of transgender victims of homicide was probably higher than the number reported because many

16. Dixon admitted "that he felt his 'manhood' was threatened by his streak of unknowingly hitting on gals who were born men.” Jacobs, supra note 8.

17. Id.

18. See Michelle Chen, Transgender Rights are Under Siege in Trump's America, The Nation (Dec. 19, 2019), https://www.thenation.com/article/transgender-rights-trump-supreme-court [https://perma.cc/LH2NZ4PQ]. Hate motivated violence against transgender individuals is on the rise. Id. (citing CTR. FOR THE STUDY OF Hate \& Extremism, Cali. State Univ., San Bernardino, Report to the Nation: Hate Crimes Rise in U.S. Cities ANd Counties In Time of Division \& Foreign InTERfEREnCE 31 (May 2018), https://www.csusb.edu/ sites/default/files/2018\%20Hate\%20Final\%20Report\%205-14.pdf (reporting that "[t]he 2017 increase in hate crime from 229 to 254 , was driven in part by the 23 crimes targeting the transgender community, which increased by 187 percent")). Some have even said that transgender individuals, particularly trans women of color, "experience rates of violence much higher than any other population in the United States." See Aimee Wodda \& Vanessa R. Panfil, "Don't Talk to Me About Deception": The Necessary Erosion of the Trans* Panic Defense, 78 Alb. L. Rev. 927, 930 (2015) (citing Jaime M. Grant et al., Nat'L Ctr. For Transgender Equal., Injustice at Every Turn: A Report of the National Transgender Discrimination Survey 3637 (2011), https://www.thetaskforce.org/injustice-every-turn-report-national-transgender-discrimination-survey/ [https://perma.cc/T3PF-YRFJ]).

19. See Doubly Victimized: Reporting on Transgender Victims of Crime, GLAAD, https://www.glaad.org/ blog/glaad-calls-increased-and-accurate-media-coverage-transgender-murders-0 [https://perma.cc/7BY6-UCB3] (last visited June 26, 2019) (listing the names of twenty-six transgender homicide victims in 2018, including Roxana Hernandez, a thirty-three year-old trans woman of color, who reportedly died while in the custody of U.S. Immigration and Customs Enforcement (ICE) after fleeing violence in Honduras); see also HuMAN RIGHTS Campaign, A National Epidemic: Fatal Anti-Transgender Violence in America in 2018 (2018) [hereinafter Human Rights CAMPAign, A NATiOnAl EPIDEMic] (“At the end of 2017, we mourned the loss of 29 [transgender and gender-expansive] people-the highest number ever recorded."); HUMAN RIGHTS CAMPAIGN, Violence AgAinst the TRANSGender COMMUNITY IN 2019, https://www.hrc.org/resources/violence-againstthe-transgender-community-in-2019 [https://perma.cc/9PCG-NSTQ] (reporting that there were twenty-six transgender homicide victims in 2018) (last visited June 25, 2019).

20. Doubly Victimized, supra note 19 (providing that of the twenty-six transgender victims of homicide in 2018 listed, twenty-five were trans women).

21. Id. (providing that of the twenty-six transgender victims of homicide listed on GLAAD's webpage, twenty-three were trans women of color). 
police officers often record the victim's biological sex, rather than their gender identity, on the police report, especially when the victim has not fully transitioned or the victim's driver's license includes only their biological sex. ${ }^{22}$ And fatal attacks - those that end in death — tell just part of the story. Each year, many transgender individuals are violently attacked in assaults that do not end in death. ${ }^{23}$

This Article shines a spotlight on a particular manifestation of violence against transgender women: when a cisgender ${ }^{24}$ man kills a transgender woman and asserts a trans panic defense. Part I discusses the widespread discrimination, harassment, and violence faced by transgender men and women in the United States today. This is not a new phenomenon. Transgender individuals have faced discrimination, harassment, and violence for many years, but verbal and physical attacks on transgender individuals seem to have become much more frequent since the election of President Donald Trump. ${ }^{25}$

Part II describes and critiques a criminal defense strategy that is commonly known as the "trans panic" defense. It shows how this strategy, invoked primarily by male defendants charged with murdering transgender women, seeks to capitalize on stereotypes about transgender individuals as sexual deviants and sexual predators. The use of this defense strategy is also problematic because of the message it sends about transgender lives.

Part III addresses the normative question of what should be done to deal with the problems identified in Part II. In the past, I did not support legislative bans on gay or trans panic defense strategies. As a former criminal defense attorney, I was reluctant to place limitations on an accused's right to present a defense. Given our adversarial system of justice, I also felt, despite my personal belief that trans panic is a reprehensible defense strategy and should be rejected by jurors, that it was best to allow defense attorneys to argue trans panic and have prosecutors combat the defense in open court.

I now believe legislative bans on the trans panic defense strategy are a necessary step in the fight against violence against transgender individuals. Part III explains my shift in position and why I now believe education as well as legislative bans on the trans panic defense strategy are imperative. It then considers potential objections to legislatively banning the trans panic defense.

22. Andrea L. Wirtz et al., Gender-Based Violence Against Transgender People in the United States: A Call for Research and Programming, 19 TRAUMA, Violence \& ABuse 1, 1, 4 (2018) (noting that because "there are no national surveillance systems that track murders of trans people and . . trans victims of violence are often misgendered by police and news media," statistics on homicides of transgender individuals likely underestimate the true rate of homicide).

23. See infra Part I.B.

24. The word "cisgender" ("cis" for short) is used in this Article to describe individuals whose gender identity matches their biological sex. See Cynthia Lee \& Peter Kwan, The Trans Panic Defense: Masculinity, Heteronormativity, and the Murder of Transgender Women, 66 HASTINGS L.J. 77, 90 (2014).

25. See infra Part III.A. 
Part IV examines recent efforts to legislatively ban gay and trans panic defense strategies. ${ }^{26}$ It discusses the ten legislative bans on gay and trans panic defenses that have been enacted to date-in California in 2014, Illinois and Rhode Island in 2018, Nevada, New York, Hawaii, Connecticut, and Maine in 2019, and most recently, New Jersey and the state of Washington in early 2020. I also examine three pending bills, two introduced in the District of Columbia and another introduced in the U.S. Congress by Senator Edward Markey (D-MA) and Representative Joe Kennedy (D-MA). While most of the statutory prohibitions follow the California legislation, there are several significant differences amongst the various proposals. Part IV discusses these differences and offers concrete suggestions as to how legislative reform in this arena can be strengthened.

\section{Violence Against Transgender Individuals}

An estimated 1.4 million people identify as transgender in the United States. ${ }^{27}$ According to the National Center for Transgender Equality, "transgender" is a term for "people whose gender identity is different from the gender they were thought to be at birth." 28 The 2015 U.S. Transgender Survey similarly notes that "the term 'transgender' is often used to describe people whose gender identity or expression differs from what is associated with the gender they were thought to be at birth." 29 A transgender woman, for example, lives as a woman, but was thought

26. AM. BAR ASS'N H.D. Res. 113A, at 1, 9, 13-14 (AM. BAR ASS'N 2013), https://lgbtbar.org/wp-content/ uploads/2014/02/Gay-and-Trans-Panic-Defenses-Resolution.pdf [https://perma.cc/9XWX-5MLU].

27. Bill Chappel, 1.4 Million Adults Identify as Transgender in America, NPR (June 30, 2016), https://www. npr.org/sections/thetwo-way/2016/06/30/484253324/1-4-million-adults-identify-as-transgender-in-america-studysays [https://perma.cc/89K9-KWP2]; ANDREW FlORES ET AL., WILLIAMS InST., How MANY ADUlTS IDENTIFY AS TRANSGENDER IN THE UNITED STATES? 3 (June 2016), https://williamsinstitute.law.ucla.edu/wp-content/uploads/ How-Many-Adults-Identify-as-Transgender-in-the-United-States.pdf (noting that "[a]n estimated $0.6 \%$ of adults, about 1.4 million, identify as transgender in the United States"); Jan Hoffman, Estimate of U.S. Transgender Population Doubles to 1.4 Million Adults, N.Y. TIMES (June 30, 2016), https://www.nytimes.com/2016/07/01/ health/transgender-population.html [https://perma.cc/S4Z7-PSTP]. This is significantly higher than the estimated transgender population in the United States five years earlier. See Lisa Langenderfer-Magruder et al., Experiences of Intimate Partner Violence and Subsequent Police Reporting Among Lesbian, Gay, Bisexual, Transgender, and Queer Adults in Colorado: Comparing Rates of Cisgender and Transgender Victimization, 31 J. INTERPERSONAL VIOLENCE 855, 856-57 (2016) (noting that nearly 700,000 or 8\% of the approximately nine million LGBTQ Americans in the United States identify as transgender (citing GARY J. Gates, Williams Inst., How ManY People ARE Lesbian, Gay, BiseXual AND TranSGENDER? 6 (April 2011), https://escholarship.org/uc/item/ 09h684x2 [https://perma.cc/2CWQ-7REF])). A Harris Poll conducted on behalf of GLAAD in 2017 found that $12 \%$ of millennials identify as transgender or gender nonconforming. See GLAAD, ACCELERATING ACCEPTANCE 2017: A Harris Poll Survey of AMERICANS' ACCEPTANCE of LGBTQ PeoPle 3 (2017), https://www.glaad.org/ files/aa/2017_GLAAD_Accelerating_Acceptance.pdf.

28. NAT'l CTR. For Transgender Equal., Frequently Asked Questions About Transgender People 1 (July 9, 2016), https://transequality.org/issues/resources/frequently-asked-questions-about-transgender-people [https://perma.cc/A8S2-QQXH].

29. NAT'L Ctr. For Transgender Equal., The Report of the 2015 Transgender Survey 40 (2015), http://www.ustranssurvey.org [https://perma.cc/Z6RK-LL6X]; see also HuMAN RigHTS CAMPAIGN, A TIME TO ACt: Fatal Violence Against Transgender PeOPle IN AMERICA IN 20175 (2017), https://assets2.hrc.org/ files/assets/resources/A Time_To_Act_2017_REV3.pdf (noting that the term "transgender" is a term commonly used "to describe people whose gender identity is different from what is typically associated with the sex 
to be male at birth. A transgender man lives as a man, but was thought to be female when he was born. Some people do not have an exclusively male or female gender, including those who identify as having no gender or more than one gender, and may use a variety of terms to describe themselves, such as non-binary. ${ }^{30}$

While the terms "sex" and "gender" are often used interchangeably, in some contexts they are treated as distinct concepts, with "sex" referring to an individual's physical attributes ${ }^{31}$ and "gender" referring to the way an individual presents himself or herself to the world. ${ }^{32}$ As Frank Valdes has noted, "sex" refers to the "physical attribute[s] of humans" while "gender" refers to the "cultural dimensions derived from and determined by sex." 33 Along these lines, a transgender individual's gender identity differs from their biological sex.

Gender identity "should not be confused with sexual orientation." 34 Sexual orientation refers to whether one is sexually attracted to members of the opposite sex (heterosexual orientation), members of the same sex (gay or lesbian), or members

assigned to them at birth (i.e., the sex listed on their birth certificate)"); Jessica A. Clarke, They, Them, and Theirs, 32 HARV. L. REV. 894, 897-98 (2019) (noting that the term "transgender" is commonly used as "[a]n umbrella term for people whose gender identity and/or gender expression differs from what is typically associated with the sex they were assigned at birth"). Some have defined the term "transgender" more broadly. See, e.g., Dean Spade, Resisting Medicine, Re/modeling Gender, 18 BERKELEY WOMEN's L.J. 15, 16 n.2 (2003) (explaining that " $[\mathrm{t}] \mathrm{ransgender}$ and trans are both political terms that have emerged in recent years to indicate a wide variety of people whose gender identity or expression transgress the rules of binary gender"); Rebecca L. Stotzer, Violence Against Transgender People: A Review of United States Data, 14 AGgRession \& VIOLENT BEHAV. 170, 171 (2009) (noting that the term "transgender" is an umbrella term that includes "cross-dressers, transsexuals, genderqueer youth, drag queens" and "anyone who bends the common societal constructions of gender"). The terms "binary gender" and "gender binary" are used to describe the fact that most people tend to think of sex and gender in binary terms — one is either a man or a woman or one is female or male — with nothing in between. See Julie A. Greenberg, Defining Male and Female: Intersexuality and the Collision between Law and Biology, 41 ARIz. L. REV. 265, 275 (1999). Janet Dolgin observes that a binary approach to gender is "deeply embedded in Western culture." Janet Dolgin, Discriminating Gender: Legal, Medical, and Social Presumptions About Transgender and Intersex People, 45 Sw. L. REV. 61, 62, 66 (2017) (noting that in contrast to this presumption that one is either male or female, "more than one percent of people are born intersex," "a condition in which a person's biological sex markers are not all clearly male or female" (quoting Julie A. Greenberg, Health Care Issues Affecting People with an Intersex Condition or DSD: Sex or Disability Discrimination?, 45 LOY. L.A. L. REV. 849, 855 (2012) (citing GLAAD Media Reference Guide-Transgender Glossary of Terms, GLAAD, http://www.glaad.org/reference/transgender [https://perma.cc/AMU3-NFVT]))). Clarke notes that "not all nonbinary people identify as transgender[.]" Clarke, They, Them, and Theirs, supra note 29, at 897-98 (2019). Terry Kogan has characterized transgender individuals as people who feel "trapped or imprisoned" in a body that does not reflect their true gender identity. Terry S. Kogan, Transsexuals and Critical Gender Theory: The Possibility of a Restroom Labeled “Other”, 48 Hastings L.J. 1223, 1225 (1997). Some trans people might resist this characterization, claiming that they feel trapped in a society that treats gender as binary. I thank my colleague, Jeremy Bearer-Friend, for sharing this insight with me.

30. THE REPORT OF THE 2015 TRANSGENDER SURVEY, supra note 29, at 40.

31. Lee \& Kwan, supra note 24 , at 87.

32. See Francisco Valdes, Queers, Sissies, Dykes, and Tomboys: Deconstructing the Conflation of "Sex," "Gender," and "Sexual Orientation" in Euro-American Law and Society, 83 CALIF. L. REV. 1, 204 (1995).

33. Id. at 6 n.5-6.

34. Lee \& Kwan, supra note 24 , at 88 . 
of the opposite sex and members of the same sex (bisexual). ${ }^{35} \mathrm{~A}$ transgender individual can be heterosexual, gay or lesbian, or bisexual. ${ }^{36}$

Violence against trans individuals in general, and trans women in particular, is more widespread than most people realize. This Part provides an overview of the extent to which trans individuals experience both fatal and non-fatal violence.

\section{A. Transgender Individuals as Victims of Homicide}

Statistics on homicides of transgender individuals across the United States are not readily available because the federal government did not start collecting data based on gender identity until recently. ${ }^{37}$ Moreover, the statistics that do exist likely do not reflect the true numbers of transgender homicide victims. Police reports often describe transgender homicide victims by their biological sex, rather than their gender identity, which leads to underreporting of the actual number of crimes of violence committed against transgender individuals. ${ }^{38}$ Indeed, the practice of calling a person by the name they were given at birth and refusing to recognize the transgender individual's gender identity is so commonplace that the transgender community has a name for it: "deadnaming," a name with a double meaning when a transgender individual is the victim of a criminal homicide. ${ }^{39}$

Given the lack of data collection on homicides involving transgender victims by the federal government, a number of private organizations concerned about the rights of transgender individuals have stepped up to fill the void. The Human Rights Campaign, for example, has been monitoring the killings of transgender people since 2013. It reports that between January 2013 and November 2018, at least 128 transgender individuals were the victims of fatal violence. ${ }^{40}$ One hundred and ten of these homicide victims (approximately 86\%) were transgender persons of color, including ninety-five black individuals and fourteen Latinos or Latinas. ${ }^{41}$

\footnotetext{
35. $I d$.

36. Id. at 88 n.33.

37. See Stotzer, supra note 29, at 176 (noting in 2009 that " $[\mathrm{t}]$ he federal government currently does not include gender identity in legislation covering hate crimes-neither in sentence-enhancements nor in mandated tracking of hate crimes in the Uniform Crime Reports"); Christine Hauser, Transgender Woman Shot Dead in Motel is 7th Killed in U.S. This Year, Rights Advocates Say, N.Y. TIMES (Mar. 30, 2018), https://www.nytimes. com/2018/03/30/us/transgender-woman-killed-baton-rouge.html [https://perma.cc/EH82-GAB2]. The FBI did add gender identity to its annual Hate Crimes Incident Report in 2012. See Jordan Blair Woods \& Jody L. Herman, Anti-transgender Hate Crime, in The Routledge InT'L HANDBoOK ON HATE CRIME 280 (Nathan Hall et al. eds., 2015). This report, however, covers all hate crime incidents, not just those resulting in death.

38. Hauser, supra note 37 ("[T]ransgender homicide victims are often identified by the police using the names and genders they were assigned at birth, a practice known as misgendering.").

39. As Lucas Waldron and Ken Schencke explain: "The transgender community has a word for calling a trans person by the name they no longer use, one that conveys a double meaning when it involves murder. It's known as "deadnaming." Lucas Waldron \& Ken Schwencke, Deadnamed, ProPublica (Aug. 10, 2018), http://www. propublica.org/article/deadnamed-transgender-black-women-murders-jacksonville-police-investigation [https:// perma.cc/8N6D-DLTU].
}

40. Human Rights Campaign, A National Epidemic, supra note 19, at 61-62.

41. Id. at 62 . 
One hundred fifteen of these transgender homicide victims were transgender women. ${ }^{42}$ In other words, nearly nine in every ten of the transgender homicide victims between January 2013 and November 2018 were transgender women. ${ }^{43}$

As reflected below, transgender women and transgender persons of color constitute the vast majority of transgender individuals who are killed in the United States each year. Since their very being rests at the intersection of race and gender identity, transgender women of color appear to be at greatest risk of being the victims of fatal violence aimed at the transgender community.

\section{Homicides Involving Transgender Victims in 2018}

According to two sources, at least twenty-six transgender or gender non-conforming individuals were killed in 2018. ${ }^{44}$ These statistics suggest that in each month in 2018, two or more transgender individuals were killed somewhere in the United States. The vast majority - twenty-five of these twenty-six homicide victims $(96 \%)$ - were transgender women. ${ }^{45}$ Twenty-three of these twenty-six transgender homicide victims in 2018 (approximately 85\%) were trans women of color. $^{46}$

\section{Homicides Involving Transgender Victims in 2017}

In 2017, the last year for which complete statistics were available at the time this Article was written, more transgender people were killed than in any year in at least a decade. ${ }^{47}$ At least twenty-nine transgender individuals were killed in the United States in 2017, the highest number ever recorded up until that time. ${ }^{48}$ These statistics suggest that in each month in 2017, at least two transgender individuals were killed somewhere in the United States. As noted above, many more transgender individuals were probably killed than reported, but their deaths may not be reflected in these figures because the police officer on the scene of the homicide may not have realized that the victim was a transgender individual or may have

\footnotetext{
42. Id.

43. Id. At least twenty-one of these transgender homicide victims were killed by intimate partners. Id. at 63 .

44. See Human Rights Campaign, Violence Against the Transgender Community in 2019, supra note 19 (reporting that there were at least twenty-six transgender or gender non-conforming homicide victims in 2018); Doubly Victimized, supra note 19 (listing the names of twenty-six transgender homicide victims in 2018, including Roxana Hernandez, a thirty-three year-old trans woman of color, who reportedly died while in the custody of U.S. Immigration and Customs Enforcement (ICE) after fleeing violence in Honduras).

45. Doubly Victimized, supra note 19 (indicating that of the twenty-six transgender victims of homicide in 2018 listed, twenty-five were trans women).

46. Id. (noting that of the twenty-six transgender victims of homicide listed on GLAAD's webpage, twentythree were trans women of color).

47. Human Rights Campaign, A Time to ACt, supra note 29, at 3.

48. Human Rights Campaign, A National Epidemic, supra note 19, at i ("At the end of 2017, we mourned the loss of 29 [transgender and gender-expansive] people - the highest number ever recorded.").
} 
simply refused to acknowledge the victim's chosen gender identity by recording the victim's biological sex, rather than their chosen gender identity, as their gender on the police report. ${ }^{49}$

\section{Homicides Involving Transgender Victims in 2016}

According to the National Coalition of Anti-Violence Programs (NCAVP), aside from the forty-nine lives lost at the Pulse Nightclub in June 2016, there were twenty-eight anti-LGBTQ homicides in $2016 .{ }^{50}$ Nineteen of these twenty-eight homicides $(68 \%)$ involved transgender or gender nonconforming victims. ${ }^{51}$ As in other years, the vast majority of these homicides, seventeen of the nineteen killings $(89 \%)$ of transgender individuals in 2016, involved transgender women of color. ${ }^{52}$

The Human Rights Campaign, which also compiles statistics on violence against transgender individuals, more conservatively reported that there were at least twenty-three homicides involving transgender victims in 2016 and that the vast majority of these victims-nineteen of the twenty-three-were transgender women. ${ }^{53}$

\section{Homicides Involving Transgender Victims in 2015}

In 2015, there were at least twenty-two homicides involving transgender victims. ${ }^{54}$ Almost every single one of these homicides - twenty-one of the twentytwo-involved a transgender female victim. ${ }^{55}$

\section{Homicides Involving Transgender Victims in 2014}

In 2014, there were at least thirteen homicides involving a transgender victim. ${ }^{56}$ All of these homicides involved a transgender female victim. ${ }^{57}$

49. Andrea L. Wirtz et al., Gender-Based Violence Against Transgender People in the United States: A Call for Research and Programming, 19 TRAUMA, VIOLEnCE \& ABUSE 1, 1, 4 (2018) (noting that because "there are no national surveillance systems that track murders of trans people and . . . trans victims of violence are often misgendered by police and news media," statistics on homicides of transgender individuals likely underestimate the true rate of homicide).

50. Nat'l Coal. of Anti-Violence Programs, A Crisis of Hate: A Report on Lesbian, Gay, Bisexual, TRANSGENDER AND QueER HATE Violence Homicides IN 20176 (2017) (reporting seventy-seven hate-inspired homicides involving LGBTQ victims in 2016, including the forty-nine lives lost in the shooting at the Pulse nightclub in Orlando, Florida in June 2016).

51. Id. at 7 .

52. Id. at 8 .

53. Human Rights CAmpaign, A National EPidemic, supra note 19, at 64.

54. Id.

55. Id.

56. Id.

57. Id. 


\section{Homicides Involving Transgender Victims in 2013}

In 2013, there were at least nineteen homicides involving a transgender victim. ${ }^{58}$ The overwhelming majority of these homicides-seventeen of the nineteeninvolved a transgender female. ${ }^{59}$

The information discussed above has been summarized in the table below.

Table 1: Homicides in the United States Involving Transgender Victims (2013-2018) ${ }^{60}$

\begin{tabular}{|c|c|c|c|}
\hline Year & $\begin{array}{c}\text { Total \# of } \\
\text { Transgender } \\
\text { Homicide Victims }\end{array}$ & $\begin{array}{c}\text { \# of Female } \\
\text { Transgender } \\
\text { Homicide Victims }\end{array}$ & $\begin{array}{c}\text { \# of Transgender } \\
\text { Homicide Victims } \\
\text { of Color }\end{array}$ \\
\hline 2013 & 19 & 17 & 17 \\
\hline 2014 & 13 & 13 & 19 \\
\hline 2015 & 22 & 21 & 20 (17 transgender \\
& 23 & 19 & 24 \\
\hline 2016 & 29 & 24 & 23 (23 transgender \\
& 26 & 25 & women of color $)$ \\
\hline 2018 & & & \\
\hline
\end{tabular}

\section{B. Transgender Individuals as Victims of Other Forms of Violence}

Information about other forms of violence against transgender individuals is also limited. Just as with homicides, the limited information available may not be accurate due to misgendering and underreporting. Additionally, transgender victims are often reluctant to report their victimization to the police out of fear of

58. Id.

59. Id.

60. Id. For the 2017 statistics, see id. at i, 64 ("At the end of 2017, we mourned the loss of 29 [transgender and gender-expansive] people - the highest number ever recorded."). For the 2018 statistics, see HuMAN RIGHTS Campaign, Violence Against the Transgender Community in 2019, supra note 19 (reporting that there were twenty-six transgender or gender non-conforming homicide victims in 2018); Doubly Victimized, supra note 19 (listing the names of twenty-six transgender homicide victims in 2018, including Roxana Hernandez, a thirty-three year old trans woman of color, who reportedly died while in the custody of U.S. Immigration and Customs Enforcement (ICE) after fleeing violence in Honduras; and noting that of the twenty-six transgender victims of homicide in 2018 listed, twenty-five were trans women, twenty-three were transgender persons of color, including twenty-two trans women of color). 
being revictimized. ${ }^{61}$ As Stephen Rushin and Jenny Carroll note, there is a "long and well-documented history of police officers in the United States mistreating the trans community." 62

The information that is available suggests that transgender individuals experience a great deal of discrimination, harassment, and physical violence. ${ }^{63}$ In 2011 , the National Center for Transgender Equality and the National Gay and Lesbian Task Force published the National Transgender Discrimination Survey, then considered the most comprehensive survey on discrimination against the trans community in the United States. ${ }^{64}$ 6,450 transgender and gender non-conforming adults across the United States participated in this survey. ${ }^{65}$ Ninety percent of the participants reported experiencing harassment, mistreatment, or discrimination at work for being transgender. ${ }^{66}$ Fifty-seven percent of the participants had experienced serious family rejection for being transgender. ${ }^{67}$ Twenty-six percent reported suffering physical assaults and ten percent reported suffering sexual assaults for being transgender or gender nonconforming. ${ }^{68}$

61. As Jordan Blair Woods and Jody Herman observe, transgender and gender non-conforming individuals may not report hate crimes to police because: (1) "they may fear that law enforcement officers and departments will mishandle or ignore their reports," (2) "they may fear that law enforcement officers will only further victimize them for being transgender or gender non-conforming," (3) they "may fear that reporting will cause the perpetrators to retaliate against them," and (4) they may not report "to avoid drawing attention to their gender identities." Woods \& Herman, supra note 37, at 280-81; see also Jan S. Redfern, Nationwide Survey of Attitudes of Law Enforcement Personnel Towards Transgender Individuals, 4 J.L. ENFORCEMENT 1, 2 (2014) (citing TALIA Bettcher et al., City of los Angeles Human Rel. Comm'n's Transgender Working Group, Recommended Model Policies and Standards for the L.A. Police Department's Interactions with TrANSGENDER Individuals 11, 14 (2010), and JAIME M. GRANT ET AL., NAT'L CTR. FOR TRANSGENDER EQUAL.,

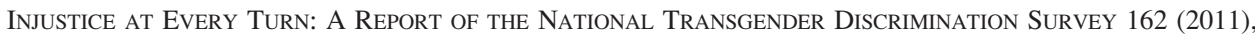
https://www.transequality.org/sites/default/files/docs/resources/NTDS_Report.pdf) (noting that the results of two surveys "reveal a general lack of trust of law enforcement by the transgender community")); see also Andrea J. Ritchie, Invisible No More: Police Violence Against Black Women and Women of Color (2017) (examining ways in which black women, indigenous women, and other women of color, including trans women of color, experience racial profiling, police violence, and immigration enforcement).

62. Stephen Rushin \& Jenny Carroll, Bathroom Laws as Status Crimes, 86 FordHAM L. Rev. 1, 20-24 (2017) (discussing thirteen studies that surveyed trans individuals about their experiences with law enforcement abuse outside of the custodial setting).

63. The absence of laws banning gender identity discrimination in many jurisdictions contributes to the difficulties transgender individuals encounter in employment, public housing, and interactions with police. See David B. Cruz, Transgender Rights After Obergefell, 84 UMKC L. REV. 693, 695 (2016) (noting that many people in the United States live in jurisdictions that do not ban gender identity discrimination, which "can make it especially challenging for transgender persons to secure employment, receive equal treatment in a range of public accommodations, and avoid police harassment").

64. Jordan Blair Woods et al., Latina Transgender Women's Interactions with Law Enforcement in Los Angeles County, 7 Policing 379, 381 (2013).

65. Jaime M. Grant et al., Nat'l Ctr. for Transgender Equal., InJustice at Every Turn: A RePORT OF THE NATIONAL TRANSGENDER DiscriminATION SURVEY 2 (2011), https://www.transequality.org/sites/default/ files/docs/resources/NTDS_Report.pdf.

66. Id. at 56 .
67. Id. at 88 .
68. Id. at 80 . 
In 2015, the National Center for Transgender Equality published an updated survey. The 2015 U.S. Transgender Survey is "the largest survey examining the experiences of transgender people in the United States." 69 27,715 transgender individuals (both adults and youth) participated. ${ }^{70}$ Thirteen percent reported that they had been subjected to a physical attack just within the past year. ${ }^{71}$ When asked about the probable reason for being attacked and who attacked them, nine percent responded that they were physically attacked specifically because of their transgender status. ${ }^{72}$ Among transgender individuals who came out to their families, ten percent of respondents reported that a family member acted violently towards them because of their transgender status. ${ }^{73}$ Five percent reported being physically attacked by strangers in public because of their transgender status. $^{74}$

When asked how many times they were physically attacked within the past year, forty-five percent reported they were attacked once, twenty-five percent were attacked twice, thirteen percent were attacked three times, and sixteen percent were attacked four or more times. ${ }^{75}$

Respondents were also asked to specify how they were attacked. ${ }^{76}$ Approximately three-quarters of the transgender individuals who had been physically attacked within the year "reported that someone had grabbed, punched, or choked them." 77 Twenty-nine percent reported that someone "threw an object at them, like a rock or a bottle."78 Three percent reported being attacked with a gun. ${ }^{79}$ Transgender women of color, particularly black and Latina women, "were nearly four times as likely to report that they were attacked with a gun." 80

Sexual violence against transgender individuals is also a pervasive problem. Nearly half of the respondents reported having been sexually assaulted at some point in their lifetime. ${ }^{81}$ When asked who committed the sexual assault against them, nearly one-third reported that they had been sexually assaulted by a

69. The Report of the 2015 TRANSGENDER SuRVEY, supra note 29, at 4.

70. Id. at 18 .

71. Id. at 202. It appears respondents were only asked whether they had experienced a physical attack during the past year, not whether they had experienced a physical attack at any time during their lifetime.

72. Id. at 203 .

73. $I d$. at 71 .

74. Id. at 203 .

75. Id. at 204 .

76. Id.

77. Id.

78. Id.

79. $I d$.

80. Id.

81. Id. at 205 (noting "[n]early half $(47 \%)$ of respondents have been sexually assaulted at some point in their lifetime"). This included "unwanted sexual contact, such as oral, genital, or anal contact, penetration, forced fondling, [and] rape." Id. The 2015 Transgender Survey also found that "transgender men (51\%) and non-binary people with female on their original birth certificate (58\%) [were] more likely to have been sexually assaulted, in contrast to transgender women (37\%) and non-binary people with male on their original birth certificate (41\%)." $I d$. The term "non-binary" is "used by some to describe people whose gender is not exclusively male or female, 
stranger. ${ }^{82}$ More than a third reported "that a current or former partner had sexually assaulted them." 83 One-quarter reported they had been sexually assaulted by a relative. $^{84}$

The 2015 survey also found a significant amount of discrimination, harassment, and physical violence directed against transgender youth. The vast majority (77\%) of trans youth who were either open about their gender identity or were perceived as transgender while in elementary, middle, or high school (K-12) experienced one or more negative experiences, such as verbal harassment, physical or sexual violence, or prohibitions against dressing according to their gender identity. ${ }^{85}$ The survey also found that transgender students in higher education experience a significant amount of verbal, physical, or sexual harassment. Of those surveyed, approximately one in every four transgender students in higher education reported some form of verbal, physical, or sexual harassment in college or vocational school because of their status as a transgender individual. ${ }^{86}$

\section{The Trans Panic Defense}

The term "trans panic defense" describes a criminal defense strategy in which a male defendant charged with murdering a transgender female victim will claim that the discovery that the victim was biologically male was so upsetting that he panicked and lost his self-control. ${ }^{87}$ The defendant will further claim he should be acquitted of murder and instead convicted of a lesser offense, such as voluntary manslaughter. ${ }^{88}$ Trans panic arguments typically are used to bolster a provocation defense, but have also been used to support mental defect defenses, such as temporary insanity or diminished capacity. ${ }^{89}$ In rare cases, a defendant may attempt to

including those who identify as having no gender, [as] a gender other than male or female, or [as] more than one gender." Id. at 40 .

82. Id. at 206.

83. Id.

84. Id.

85. Id. at 131-32.

86. Id. at 136.

87. See Lee \& Kwan, supra note 24 , at 77.

88. Id.

89. The defendant might argue that he temporarily became insane upon learning that the victim was born male or he might claim that he lacked the specific intent to kill required for murder because learning that the victim was born male diminished his mental capacity. For example, in one case out of Fresno, California, a twentythree-year-old man named Estanislao Martinez stabbed the victim, a Latina transgender female, twenty times with a pair of scissors after discovering the victim was biologically male. RIKI WILCHINS \& TANEIKA TAYLOR, Gender Pub. Advoc. Coal., 50 Under 30: Masculinity and the War on America's Youth, A Human Rights REPORT 11 (2006). Apparently, Martinez met Joel Robles, whom Martinez thought was born female, on a blind date and went back to Martinez's apartment to engage in sexual activity. Man Gets Four Years in Prison for Transgender Slaying, Fox News (Oct. 1, 2005), https://www.foxnews.com/story/man-gets-four-years-inprison-for-transgender-slaying [https://perma.cc/GSP3-YU7V]. In court, Martinez's lawyer argued that his client realized Robles was a man after they engaged in some sexual activity. Id. His client then flew into a rage, and "the panic (his client) felt was a sort of temporary insanity brought on by the shock of realizing he had been duped by a transgender man." Id. Martinez's attorney argued that this rage meant that what his client did was not 
use a trans panic argument in connection with a self-defense claim. ${ }^{90}$ Because the most common way trans panic arguments operate is within the structure of the defense of provocation, I focus on how trans panic fits within the doctrinal site of the provocation defense. I start by providing an overview of the defense of provocation.

\section{A. The Defense of Provocation}

The defense of provocation, also known as the heat of passion defense, is a partial defense to murder. ${ }^{91}$ If the jury finds that the defendant was provoked into a heat of passion by legally adequate provocation, it can acquit the defendant of murder and instead convict him of voluntary manslaughter, a lesser crime with a correspondingly lighter sentence than the sentence for murder. ${ }^{92}$

"Legally adequate provocation" is a legal term of art. At early common law, legally adequate provocation existed if and only if the defendant fell within one of the following categories: "(1) an aggravated assault or battery, (2) the observation of a serious crime against a close relative, (3) an illegal arrest, (4) mutual combat, or (5) catching one's wife in the act of adultery." 93 Only these categories of provocative acts were recognized at early common law as legally adequate provocation. $^{94}$

murder. Id. Martinez was allowed to plead guilty to voluntary manslaughter, and while he could have been sentenced to eleven years, he was instead sentenced to four years in prison. Id. Three years were for the voluntary manslaughter charge and an additional year was added for using scissors as a weapon. See Wodda \& Panfil, supra note 18 , at $954-55$.

90. In State v. Camacho, No. A-5189-07T4, 2010 WL 3218888 (N.J. Super. Ct. App. Div. Aug. 16, 2010), for example, according to the defendant's statement to police, the victim was dressed in feminine attire and offered the defendant twenty dollars to have sex. See Jordan Blair Woods et Al., Williams Inst., Model Legislation for Eliminating the Gay and Trans Panic Defenses 12 (2016), https://williamsinstitute.law. ucla.edu/research/transgender-issues/model-legislation-for-eliminating-the-gay-and-trans-panic-defenses/. After entering the victim's apartment, the victim undressed. Id. The defendant claimed he got angry when he saw the victim's genitals and thought the victim was going to grab a knife the defendant had in his jacket, so he stabbed and killed the victim. $I d$. The defendant was found guilty of first-degree murder. $I d$. On appeal, the defendant argued that his trial attorney was ineffective for, among other things, failing to request an instruction on selfdefense and imperfect self-defense. $I d$. The appellate court rejected the defendant's ineffective assistance of counsel claim. Id.

91. Cynthia Lee, Murder and the Reasonable Man: Passion and Fear in the Criminal Courtroom 25 (NYU Press 2003). A partial defense is one in which the defendant is acquitted of the charged offense but found guilty of a lesser offense. See Joshua DrESSLER, UNDERSTANDING CRIMINAL LAW § 16.01, at 193 n.2 (Carolina Academic Press, 8th ed. 2018) (noting that "[s]ome defenses result in the defendant's conviction of a lesser offense [and] are ... described as "partial defenses"”).

92. Dressler, Understanding CRIminal LAW, supra note 91, § 31.07[A], at 501 (noting that "[a]t common law, an intentional homicide committed in 'sudden heat of passion' as the result of 'adequate provocation' mitigates the offense to voluntary manslaughter").

93. Cynthia Lee \& Angela Harris, Criminal Law: Cases And Materials 343 (4th ed. 2019) (explaining the circumstances under which one could claim the provocation mitigation under the early common law's categorical approach); see also DRESSLER, UNDERSTANDING CRIMINAL LAW, supra note 91, § 31.07[B][2][a], at 502.

94. Dressler, Understanding CRiminal Law, supra note 91, \$31.07[B][2][a], at 502 (noting that "[c]ommon law courts developed a small and fixed list of categories that met this standard [of constituting 
The early common law's rigid categorical approach to provocation came under increasing criticism at least in part because it was thought unfair to male murder defendants who could not meet its stringent requirements. ${ }^{95}$ In the late 1800 s, many jurisdictions began to abandon the early common law approach to provocation, replacing it with an approach that employed a reasonableness requirement to determine which types of provocation were legally adequate. ${ }^{96}$ In most jurisdictions today, legally adequate provocation exists if the hypothetical reasonable person in the defendant's shoes would have been ${ }^{97}$ provoked into a heat of passion. ${ }^{98}$

adequate provocation]”); LEE \& HARRIS, CRIMINAl LAW: CASES AND MATERIALS, supra note 93, at 343 (“Only these categories of provocative acts were recognized at early common law as adequate provocation[.]").

95. LEe, MuRder AND THE ReAsonable MAN, supra note 91, at 24 ("Not only was the early categorical approach seen as unfair to unmarried men who claimed they were provoked into killing their unfaithful fiancées or girlfriends, it was also thought to be unfair to married men who learned of their wives' adultery through third parties or through their wives' own confessions."). The early categorical approach was also very unfair to wives charged with murdering their unfaithful husbands after catching them in the act of adultery, since the last category only applied to husbands who killed their unfaithful wives after catching them in the act of adultery. But this unfairness to female defendants did not move courts to abandon the categorical approach. Id. ("Eventually, the early common law's highly rigid categorical approach to provocation came under increasing criticism, not because it was seen as unfair to women who killed their unfaithful husbands, but because it was thought unfair to male murder defendants who could not meet the early common law's stringent requirements.").

96. LeE, Murder AND the Reasonable Man, supra note 91, at 25 (noting that "[f]or a defendant to receive the provocation mitigation, the jury must find that (1) the defendant was actually provoked into a heat of passion, (2) the reasonable person in the defendant's shoes would have been so provoked, (3) the defendant did not cool off, and (4) the reasonable person in the defendant's shoes would not have cooled off'); see also DRESSLER, UNDERSTANDING CRIMINAL LAW, supra note 91, § 31.07[B][2][b][i], at 503 (noting that adequate provocation under modern law may be found if the provocation "would render any ordinarily prudent person for the time being incapable of that cool reflection that otherwise makes it murder" or "might render ordinary men, of fair average disposition, liable to act rashly or without due deliberation or reflection, and from passion, rather than judgment") (internal quotations and citations omitted).

97. There appears to be some debate over whether the modern test focuses on whether the reasonable person "would have" been provoked into a heat of passion or whether it simply requires that the reasonable person "could have" been provoked into a heat of passion. Most of the available sources suggest the question is whether the reasonable person "would have" been provoked. Id.; see also In re Standard Jury Instructions In Criminal Cases-Report No. 2013-02, 137 So.3d 995, 997-98 (Fla. 2014) (authorizing changes to Florida's standard jury instructions, which state that adequate provocation requires that "a reasonable person would have lost normal self-control and would have been driven by a blind and unreasoning fury") (emphasis added); State v. Herrick, 30 A.3d 1285, 1291 (Vt. 2011) (affirming jury instructions that “"[a]dequate provocation' refers to the degree of provocation that would cause a reasonable person to lose self-control and to act without thinking") (emphasis added); People v. Pouncey, 471 N.W.2d 346, 389 (Mich. 1991) ("In addition, the provocation must be adequate, namely, that which would cause the reasonable person to lose control.") (emphasis added). A few courts have used the word "might" to describe the test, supporting the view that the test is whether the reasonable person "could have" been provoked. See, e.g., Dandova v. State, 72 P.3d 325, 332 (Alaska Ct. App. 2003) ("Loosely speaking, a provocation was adequate if it was "such as might naturally induce a reasonable [person] in the passion of the moment to lose self-control and commit the act on impulse and without reflection.'") (emphasis added) (citation omitted); State v. Tucker, No. W2000-02220-CCA-R3CD, 2002 WL 31624933, at *14 (Tenn. Crim. App. Nov. 20, 2002) (affirming jury instruction where the judge instructed that "[a]dequate provocation is one that excites such anger as might obscure the reason or dominate the volition of an ordinary reasonable man") (emphasis added).

98. Dressler, Understanding Criminal Law, supra note 91, § 31.07[B][2][b][i], at 503. This test is often called the modern reasonable person test, although it is sometimes referred to as the modern common law test to 
The critical question in provocation cases is whether the provocation was legally adequate or reasonable. ${ }^{99}$ However, as Jonathan Witmer-Rich notes, legal scholars have struggled for years to articulate principled standards to assess the reasonableness or adequacy of the provocation. ${ }^{100}$

An alternative formulation of the provocation defense was proposed in 1962 by the American Law Institute ("ALI"). Under the ALI's Model Penal Code ("MPC"), a killing that would otherwise be murder constitutes manslaughter if the killing "is committed under the influence of extreme mental or emotional disturbance for which there is reasonable explanation or excuse."101 Unlike the modern reasonable person test for provocation, the MPC's extreme mental or emotional disturbance defense does not assess the adequacy of the provocation by asking whether an objectively reasonable person would have been provoked into a heat of passion. Rather, the MPC specifies that "reasonableness . . . shall be determined from the viewpoint of a person in the actor's situation under the circumstances as he believes them to be."102 In other words, the MPC expressly adopts a subjective approach to the reasonableness inquiry. ${ }^{103}$ Only ten to twelve states have adopted the MPC's approach to provocation. ${ }^{104}$

differentiate it from the early common law test or simply the common law test to differentiate it from the MPC approach to provocation.

99. Roger M. Goldman ET AL., 4 CRiminal LAW AdVocacy $\$ 68.03$ (2019) (noting that "[the] provocation must be recognized as adequate by law").

100. Jonathan Witmer-Rich, The Heat of Passion and Blameworthy Reasons to Be Angry, 55 AM. CRIM. L. REV. 409, 422-37 (2018). Witmer-Rich suggests that the correct standard is one in which courts would ask whether the defendant's reason for becoming extremely angry is itself blameworthy. Id. at 461 .

101. Model PenAl Code $\$ 210.3(1)$ (b) (AM. LAW InST. 1962).

102. Id.

103. The Model Penal Code's subjective approach makes it easier for defendants claiming the mitigation to obtain favorable results than if they were in jurisdictions applying the modern reasonable person test for provocation. See Victoria Nourse, Passion's Progress: Modern Law Reform and the Provocation Defense, 106 YALE L.J. 1331, 1354-55 (1997).

104. Michal Buchhandler-Raphael, Fear-Based Provocation, 67 AM. U. L. REv. 1719, 1728 (2018) (noting that only twelve jurisdictions have adopted the MPC's extreme emotional disturbance defense) (citing Paul H. Robinson, Murder Mitigation in the Fifty-Two American Jurisdictions: A Case Study in Doctrinal Interrelation Analysis, 47 TeX. Tech. L. Rev. 19, 25 (2014) (listing Hawaii, Montana, Nevada, New Hampshire, Arkansas, Connecticut, Delaware, Kentucky, New York, North Dakota, Oregon and Utah as the twelve states that have adopted something like the MPC's extreme mental or emotional disturbance defense)). The number of states that utilize the MPC's extreme emotional disturbance defense may be even fewer than twelve. It appears Nevada and Connecticut have switched to the modern test for provocation since legislation in these states banning the gay and trans panic defenses do not use the words "extreme mental or emotional disturbance" but instead use the words "provocation" or "heat of passion." See NEV. REV. STAT. ANN. § 193.225(1) (2019) (providing that an alleged heat of passion or provocation is not objectively reasonable "if it resulted from the discovery of, knowledge about or potential disclosure of the actual or perceived sexual orientation or gender identity or expression of the victim"); CONN. GEN. STAT. § 53a-16 (2019) (noting that "[j]ustification . . . does not include provocation that resulted solely from the discovery of, knowledge about or potential disclosure of the victim's actual or perceived sex, sexual orientation or gender identity or expression"). 


\section{B. The "Gay Panic Defense"}

In the late 1960s and early 1970s, male defendants charged with murdering gay men began to utilize the concept of "homosexual panic" in connection with claims of insanity or diminished capacity. ${ }^{105}$ These defendants would argue that the gay male victim's unwanted, nonviolent sexual advance triggered in them a violent psychotic reaction, causing them to lose control over their mental abilities. ${ }^{106}$ Most of these early claims of gay panic to support a mental defect defense like insanity were not successful. ${ }^{107}$

As time went on, male murder defendants charged with killing gay men started using the idea of homosexual panic as part of a provocation defense with more success. ${ }^{108}$ These defendants would argue that a nonviolent sexual advance by their male victim provoked them into a heat of passion, causing them to lose control over their actions. ${ }^{109}$

105. State v. Thornton, 532 S.W.2d 37, 44 (Mo. 1975) (noting that defense was arguing defendant was in a state of "homosexual panic" at the time of the stabbing); People v. Parisie, 287 N.E.2d 310, 313 (Ill. App. Ct. 1972) (noting that defense was arguing insanity based on "homosexual panic"); People v. Rodriguez, 64 Cal. Rptr. 253, 255 (Cal. Ct. App. 1967) (noting that psychiatrist for the defense testified that defendant was acting as a result of acute homosexual panic brought on by his fear that the victim was molesting him).

106. Cynthia Lee, The Gay Panic Defense, 42 U.C. DAvis L. Rev. 471, 491 (2008) (citing Duncan Osborne, The Homosexual Panic Defense: Are Juries Really Buying It?, LGNY News (Nov. 4, 1999)).

107. Id. at 492 (citing Robert G. Bagnall et al., Comment, Burdens on Gay Litigants and Bias in the Court System: Homosexual Panic, Child Custody, and Anonymous Parties, 19 HARV. C.R.-C.L. L. REV. 497, 501 (1984)).

108. Id. at 500-05. The actual number of cases in which gay panic has been asserted is uncertain since most criminal cases end in a guilty plea. See Missouri v. Frye, 566 U.S. 134, 143 (2012) (noting that "[n]inety-seven percent of federal convictions and ninety-four percent of state convictions are the result of guilty pleas" and plea negotiations are shrouded in secrecy). The gay panic cases that are known are those that have received extensive press coverage and those that are published in court opinions. Most successful gay panic cases, however, are not likely to be in published court opinions. If the defendant gets the voluntary manslaughter verdict that he was seeking, he is not likely to appeal his conviction. The government is also unlikely to appeal because the double jeopardy clause prohibits the government from retrying a defendant for the same offense. Nonetheless, one researcher found 189 appellate criminal cases between 1952 and 2005 in which the defense referenced unwanted gay sexual advances-either as part of a formal trial strategy or in their description of the facts-and was successful in gaining the defendant a reduced sentence in $13 \%$ of these cases. See Jessica M. Salerno et al., Excusing Murder? Conservative Jurors' Acceptance of The Gay-Panic Defense, 21 PsYCHOL. PuB. POL'Y \& L. 24, 25 (2015) (citing E. Harrington, Poster, American Psychology-Law Society Conference, San Antonio, TX, Provocation as a Murder Defense: An Analysis of Appellate Cases Involving Homosexual or "Gay Panic" (March 2009)). According to another source, gay panic strategies have been asserted in at least forty-five cases nationwide between 2002 and 2016. See James Nichols, American Bar Association Votes to Curtail Use of 'Gay Panic,' 'Trans Panic' Defense, Huff. Post (Aug. 16, 2013), https://www.huffpost.com/entry/american-barassociation-gay-panic_n_3769149? guccounter=1\&guce_referrer=aHR0cHM6Ly93d3cuZ29vZ2x1LmNvbS8\& guce_referrer_sig=AQAAAIDWMDyf_caD1ecojUG4vRAHbwqan-WoVLXMnhk65qBXXRpe1Z2VoWmrSRO baPAetc33eticfznXj7W9YEHCilKSAM4LxAwjaoey5XrNaQoaCQjoeLbocqnfL41i3WKuyRzY31O5c2qUtS1 9p65UOondmGvMBt3T3k0_fmWSgMJ [https://perma.cc/F33N-86DG].

109. Lee, The Gay Panic Defense, supra note 106, at 500-04 (discussing Schick v. Indiana, 570 N.E.2d 918 (Ind. Ct. App. 1991), in which a male defendant successfully argued he was provoked into a heat of passion by his male victim's unwanted sexual overture; and Mills v. Shepard, 445 F. Supp. 1231 (W.D.N.C. 1978), in which a male defendant successfully argued that he was provoked into a heat of passion by his male victim's attempt to have sex with him). 
The defendant-friendly verdicts in these early gay panic provocation cases were likely the product of a culture that privileged male violence over other forms of violence. ${ }^{110}$ A man who responded to a gay man's nonviolent sexual advance with deadly violence was thought to be acting the way an ordinary man would react. ${ }^{111}$ If, however, a woman had killed a man who groped her breasts and tried make a similar claim (i.e., "I was reasonably provoked into a heat of passion by the victim's unwanted nonviolent sexual advance"), her claim of reasonableness would not have been likely to succeed given the prevailing social norms at that time. As I have argued in my previous scholarship, women in society were "supposed to accept a certain amount of unwanted male attention, and while they might frown, struggle, or protest, they [were] not supposed to use violence to dissuade or thwart men who suggest[ed] sexual interest" in these inappropriate ways. ${ }^{112}$ "[W]omen [were] taught to believe that a man who aggressively expresses his sexual attraction for a woman [was] merely behaving the way a man is supposed to behave" 113 and were supposed to be flattered if they were the target of unwanted male attention. ${ }^{114}$ It is not clear that this would still be the case in today's \#MeToo culture.

Defendant-friendly verdicts were also the product of a culture that privileged heterosexual men over gay men. At least back then, and perhaps still today in some places in America, if a heterosexual man responded violently to a gay man's sexual advance, he enjoyed a presumption of reasonableness. ${ }^{115}$ A heterosexual man was expected to become outraged if another man attempted to make a sexual advance upon him. If, however, a gay man were to respond violently to an unwanted nonviolent sexual advance by a woman, given societal norms privileging heterosexuality, most people would probably say that he was not acting as an ordinary man would have acted, even if the woman's nonviolent sexual advance was just as offensive to him as a gay man's sexual advance might be to a heterosexual man. ${ }^{116}$

Since I have previously written at great length about the "gay panic defense," 117 I will now turn to the trans panic defense, a close cousin of the gay panic defense. Trans panic is typically asserted by a male defendant charged with murdering a transgender female. As explained below, the defendant in a trans panic case claims that the discovery that the victim was a transgender person provoked him into a heat of passion.

110. Id. at 510 .

111. Id. at 505.

112. Id. at 510.

113. Id.

114. Id. at 510-11.

115. Id. at 511.

116. Id.

117. Lee, The Gay Panic Defense, supra note 106; see also Cynthia Lee, Masculinity on Trial: Gay Panic in the Criminal Courtroom, 42 Sw. L. REV. 817 (2013). 


\section{The Trans Panic Defense}

A murder defendant claiming trans panic typically will allege that he became upset and lost his ability to control his actions upon discovering that the victim was a transgender female. In states that follow the modern formulation of the provocation defense, the defendant must also show that a reasonable person would have been provoked into a heat of passion in order to receive the mitigation from murder to voluntary manslaughter. ${ }^{118}$ For years, courts have equated reasonableness with typicality, construing the reasonable person as the ordinary or typical person. ${ }^{119}$ Consequently, the defendant claiming trans panic will argue that the ordinary man in his shoes would have been provoked into a heat of passion, and therefore he should be found not guilty of murder, but instead guilty of voluntary manslaughter.

It is not difficult for the defendant asserting a trans panic defense to satisfy the requirement that he was actually provoked into a heat of passion. All the defendant has to do is testify that he became so upset upon discovering the victim was a transgender female that he lost his self-control. If the jury believes the defendant, the defendant can satisfy the "actually provoked" requirement.

It may also not be too difficult for a defendant who claims trans panic to satisfy the reasonableness requirement. The defendant need only convince the jury that the average or ordinary man would become very upset if he discovered that an individual he had been dating or courting was not born female.

118. See LeE, Murder AND THE ReAsonable MAN, supra note 91, at 25 (noting that one of the requirements for the provocation defense is a finding that the reasonable person in the defendant's shoes would have been provoked); DRESSLER, UNDERSTANDING CRIMINAL LAW, supra note 91, § 31.07[B][2][b][i], at 503 (noting that adequate provocation under modern law may be found if the provocation "might render ordinary men, of fair average disposition, liable to act rashly ... and from passion, rather than judgment") (internal quotations and citations omitted); 2 Wayne R. LAFAve, 2 Substantive Criminal LaW §15.2(b) (3d ed. 2019) ("What is really meant by 'reasonable provocation' is provocation which causes a reasonable man to lose his normal selfcontrol.").

119. Joshua Dressler, When "Heterosexual" Men Kill "Homosexual" Men: Reflections on Provocation Law, Sexual Advances, and the "Reasonable Man" Standard, 85 J. CRIM. L. \& CRIMINOLOGY 726, 753 (1995) (noting that " $[\mathrm{t}]$ he Reasonable Man in the context of provocation law ... is more appropriately described as the Ordinary Man (i.e., a person who possesses ordinary human weaknesses)" as opposed to an idealized human being); see also People v. Beltran, 56 Cal. 4th 935, 957 (2013) (noting “[p]rovocation is adequate only when it would render an ordinary person of average disposition 'liable to act rashly or without due deliberation and reflection, and from this passion rather than from judgment"') (emphasis added) (quoting People v. Logan, 175 Cal. 45, 49 (1917)); Commonwealth v. Glover, 459 Mass. 836, 841 (2011) (noting that "[r]easonable provocation is provocation that 'would have been likely to produce in an ordinary person such a state of passion, anger, fear, fright, or nervous excitement as would eclipse his capacity for reflection or restraint"') (emphasis added) (quoting Commonwealth v. Walden, 380 Mass. 724, 728 (1980)). Courts tend to equate reasonableness with typicality not just in provocation cases, but also in self-defense cases. See Cynthia Kwei Yung Lee, Race and Self-Defense: Toward a Normative Conception of Reasonableness, 81 MinN. L. REV. 367, 495 (1996) (noting that in self-defense cases, legal decisionmakers tend to "evaluate the reasonableness of the defendant's beliefs and actions by trying to determine whether the ordinary reasonable person would have believed and acted the way the defendant did"). 
While such an argument might seem absurd to many people, it would likely resonate with many others. ${ }^{120}$ Aimee Wodda and Vanessa Panfil recount a familiar scene playing out on the Jerry Springer show that supports the suggestion that the average cisgender heterosexual man would react with physical violence if he found out that the woman to whom he was attracted was a transgender female:

A woman sits on a stage and tells a talk show host that a man who has "liked" many of her pictures on Instagram has wanted to meet her for a month, but it had not yet happened because they live in different parts of the country. He called the talk show in order to facilitate their meeting, and she obliged. However, she tells the talk show host: "But he don't know my secret." When the host asks her what it is, she replies that she is transgender, to which the audience makes loud "oooooh" noises....

The talk show host brings out her admirer. The man comes out onto the stage, greets the host, hugs his crush, and sits down next to her. After a brief exchange of hellos, she says, "Well, before we go any further, I need to letchu know something. Umm, I haven't really taken it seriously because we've only been talking for a month, and we live so far, I never planned on meetin' you, but I'm lettin' you know, I was born a man." Her admirer asks the host, "Is she serious, Jerry?" Before even receiving an answer, he jumps onto the woman, his arms swinging at her, and the show's security guards spring into action as the audience erupts in cheers, hoots, laughter, and applause. . . The security guards pry the combatants apart and separate them to opposite sides of the stage....

The woman [asks]: "Why are you so mad? We didn't sleep together." He yells, “. . . Cuz you deceived me!"121

Wodda and Panfil note that "segments featuring a woman who was 'born a man' and is there to reveal this to a sexual or romantic partner have been popular on the show"122 and that "the majority of transgender guests [on the show] are met with scorn, derision, disgust, anger, and violence." ${ }^{123}$ Wodda and Panfil also point out that this audience reaction is not that surprising given that transgender and gender nonconforming individuals are often "portrayed in the media as curiosities or

120. Americans today have more negative feelings toward trans people than other groups. See German Lopez, We Asked US Voters About Their Views on Transgender People. Here's What They Said, Vox (May 24, 2016), https://www.vox.com/2016/5/24/11746086/transgender-bathrooms-poll-survey [https://perma.cc/6NFDFBFP]. One in five Americans believe that transgender individuals have a mental illness. See Samantha Allen, Why A Lot of Americans Don't Want To Befriend a Transgender Person, DAILY BEAST (May 19, 2017), https:// www.thedailybeast.com/why-a-lot-of-americans-dont-want-to-befriend-a-transgender-person?ref=scroll [https:// perma.cc/6TFM-VXFG].

121. Wodda \& Panfil, supra note 18 , at $927-28$.

122. Id. at 928 .

123. Id. at 929 . Even though some aspects of the Jerry Springer show appear to be staged, such as the on stage fighting between guests on the show, the show appears to be tapping into an anti-trans sentiment that a large proportion of the audience seems to share. Id. 
oddities, as mentally unstable persons, and/or as predators." 124 They note that "a general feeling of disgust or revulsion towards gender nonconforming persons may be . . . a contributing factor in cases of transphobic acts of violence." 125

While trans panic arguments are usually seen in cases in which a cisgender man has been charged with murder and seeks mitigation of the murder charge to voluntary manslaughter, a cisgender man charged with manslaughter in the death of a transgender woman will sometimes make a similar argument in the hopes of getting mitigation to an even lesser charge. For example, in the case discussed in the Introduction, Dixon, the man who killed Islan Nettles, a twenty-one-year-old African American transgender woman, ${ }^{126}$ was charged with first-degree man slaughter. ${ }^{127}$ As a result of a plea agreement with the prosecution, Dixon entered a plea of guilty to second-degree manslaughter and first-degree assault and was sentenced to twelve years in prison. ${ }^{128}$

\section{Problems with the Trans Panic Defense Strategy}

Trans panic arguments are problematic for many reasons. I briefly outline some of those reasons here. ${ }^{129}$

\section{a. The Trans Panic Defense Suggests Transgender Individuals are Sexually Deviant}

First, trans panic arguments reinforce negative stereotypes about trans people. Implicit in the trans panic argument is the idea that transgender individuals are sexually deviant. A homicide case involving a gender-nonconforming victim from Oxnard, California reflects this view. ${ }^{130}$ Brandon McInerney was a fourteen-yearold male who shot and killed his fifteen-year-old classmate Larry King on February 13, 2008. ${ }^{131}$ King was described in news reports about the case as a gay

124. Id. at 932; see also id. at 932 n.26 (listing films in which transgender or gender nonconforming individuals were portrayed as predators, including Dressed to Kill, In Dreams, Psycho, The Silence of the Lambs, Sleepaway Camp, etc.).

125. Id. at 931.

126. Rankin, supra note 1.

127. Wang, supra note 2.

128. Rankin, supra note 1 (noting that the judge sentenced Dixon to twelve years even though the original plea agreement was for a seventeen-year sentence); see also Wang, supra note 2. It is difficult to know what motivated the government to agree to these lesser charges. Perhaps the prosecutor feared Dixon's trans panic argument might convince jurors to be lenient on him. Rather than risk a complete acquittal, the prosecutor may have thought it better to secure a conviction on these lesser charges.

129. For examples and explanation of these arguments in greater depth, see Lee \& Kwan, supra note 24, at 108-19.

130. For an insightful and comprehensive examination of the trial in the Brandon McInerney case, see J. Kelly Strader et al., Gay Panic, Gay Victims, and the Case for Gay Shield Laws, 36 CARDOZO L. ReV. 1473 (2015).

131. Catherine Saillant, Mistrial Declared in Slaying of Gay Oxnard Teen, L.A. TIMES, Sept. 2, 2011, at AA1; Catherine Saillant, Trial in Killing of Gay Teen Will Test New Law, L.A. TIMES, July 21, 2011, at AA1. 
male teenager, ${ }^{132}$ and even described himself as gay, ${ }^{133}$ but appears to have been a gender-nonconforming teenager or a transgender female. ${ }^{134}$ King began wearing makeup and high heels to school in January $2008 .{ }^{135} \mathrm{He}$ was also planning to change his name from Larry to Leticia. ${ }^{136}$

McInerney claimed that he was provoked into a heat of passion by King's sexually provocative actions, including asking McInerney to be his Valentine a few days before the shooting and blowing a kiss at McInerney the day before the shooting. ${ }^{137}$

McInerney told one of King's friends that she should say goodbye to King because she would never see him again. ${ }^{138}$ The next day, McInerney brought a loaded .22 caliber handgun to school, hiding it in his backpack. ${ }^{139} \mathrm{He}$ went into a classroom where King was working on a paper, walked up behind King, then shot King twice in the back of the head. ${ }^{140}$

Despite the strong evidence of premeditation and deliberation that supported a first-degree murder conviction, the jury could not come to an agreement. ${ }^{141} \mathrm{~A}$

132. Catherine Saillant \& Richard Winton, Retrial in Gay Youth's Shooting to Omit Hate Allegation, L.A. Times, Oct. 6, 2011, at A1.

133. Rebecca Cathcart, Boy's Killing, Labeled a Hate Crime, Stuns a Town, N.Y. TIMES (Feb. 23, 2008), https://www.nytimes.com/2008/02/23/us/23oxnard.html?mtrref=www.google.com\&assetType=REGIWALL [https://perma.cc/8YLE-C335]. As a young teenager, King may not have understood the difference between sexual orientation and sexual identity. See JANET Mock, Redefining ReAlnESS: My PATH TO WomanHOOD, IdENTITY, Love \& So MUCH More 80 (2014) (noting that "a trans girl who is assigned male at birth and attracted to boys may call herself gay for a short time-a transitional identity on her road to self-discovery").

134. In this documentary film about the death of Larry King, King's friend Aliyah says, "I don't think that Larry is gay. He's transgendered. It's a big difference." VALENTINE ROAD 35:24 (Bunim-Murray Production \& Eddie Schmidt Productions 2013).

135. Ramin Setoodeh, Young, Gay and Murdered in Junior High, NewsweEK, July 28, 2008, at 41.

136. Id.

137. Id:; Jim Dubreuil \& Alice Gomstyn, Was Teen Shooter Victim of Bullying, Sexual Harassment?, ABC NEws (Oct. 4, 2011), https://abcnews.go.com/US/teen-shooter-victim-sexual-harassment/story?id=14663570 [https://perma.cc/7XVL-RA8N].

138. Setoodeh, supra note 135 .

139. Calif. Teen Brandon McInerney Sentenced to 21 Years for Point-Blank Murder of Gay Classmate, CBS NEws (Dec. 19, 2011), http://www.cbsnews.com/news/calif-teen-brandon-mcinerney-sentenced-to-21-years-forpoint-blank-murder-of-gay-classmate [https://perma.cc/3GE8-Y4M4]; Jim Dubreuil \& Denise MartinezRamundo, Boy Who Shot Classmate at Age 14 Will Be Retried as Adult, ABC News (Oct. 5, 2011), https:// abcnews.go.com/US/eighth-grade-shooting-larry-king-brandon-mcinerney-boys/story?id=14666577 [https:// perma.cc/G5Z4-WXG9].

140. Setoodeh, supra note 135, at 45-46; Rebecca Cathcart, Boy's Killing, Labeled a Hate Crime, Stuns a Town, N.Y. TIMES (Feb. 23, 2008), https://www.nytimes.com/2008/02/23/us/23oxnard.html [https://perma.cc/ 2GH5-WLWJ] (reporting that on the morning of February 12, Lawrence was in the school's computer lab when Brandon walked into the room with a gun and shot Lawrence in the head); Ken Corbett, A Murder Over a Girl, HuFf. Post (Apr. 4, 2016), https://www.huffpost.com/entry/a-murder-over-a-girl b 9595260 [https://perma.cc/ S92P-A6P6] (reporting that McInerney shot King twice in the back of the head); Dubreuil \& Martinez-Ramundo, supra note 139 (reporting that teacher Dawn Boldrin reported she was in the computer lab on the day of the shooting when she heard a pop, saw Brandon holding a handgun, asked him what he was doing, and Brandon looked at her and pulled the trigger again).

141. Catherine Saillant, Gay Teen's Killer Takes 21-Year Deal, L.A. Times, Nov. 22, 2011, at AA1 ("McInerney's first trial ended in a hung jury in early September, with jurors torn between murder and manslaughter."). 
majority of the jurors were persuaded by the defense's argument that McInerney was reasonably provoked into a heat of passion by King's behavior and felt manslaughter was more appropriate than murder. ${ }^{142}$ Apparently, these jurors blamed King for his own death and felt King had provoked McInerney into killing him.

One juror felt so strongly that King was at fault for his own death that she took the time to write to the District Attorney after the trial was over. Juror No. 11 told the District Attorney that she felt the prosecution of McInerney was a "witch hunt," writing:

You all know this was not a hate crime. You all know the victim had a long history of deviant behavior. Yes, I said deviant . . . deviant behavior. . . . [The defendant] reacted to being bullied and being the target of Larry King's sexual harassment. There was provocation. ${ }^{143}$

The association between transgender people and the notion of sexual deviance is so strong that many transgender individuals are stopped by police on suspicion of soliciting prostitution. In fact, this happens so frequently that those in the transgender community have a name for the practice: "Walking While Trans," analogy to "Driving While Black," the phrase used to refer to the commonplace practice of police pulling over law-abiding black people on suspicion of criminal activity while driving. ${ }^{145}$

\section{b. The Trans Panic Defense Suggests the Victim Deserved to Die}

Trans panic arguments also suggest the transgender victim deserves to die. While the defense of provocation is usually understood to be a partial excuse,

142. See Strader et al., supra note 130, at 1493; Catherine Saillant, Mistrial Declared in Slaying of Gay Oxnard Teen, L.A. TIMES (Sept. 2, 2011), https://www.latimes.com/local/la-xpm-2011-sep-02-la-me-0902-gaystudent-20110902-story.html ("Jurors deadlocked 7 to 5 in favor of voluntary manslaughter in the emotional two-month trial[.]"); Mistrial Declared in Killing of Gay California Student, CNN (Sept. 8, 2011), [https:// perma.cc/R5CB-C9CW] ("The nine-woman, three-man jury panel said its last vote resulted in seven in favor of finding the defendant guilty of voluntary manslaughter[.]").

143. Letter from Juror No. 11 to District Attorney Gregory D. Totten (Sept. 28, 2011) (on file with author). The author thanks Professor Kelly Strader of the Southwestern Law School in Los Angeles, California for sharing this letter.

144. Kate Greenberg, Still Hidden in the Closet: Trans Women and Domestic Violence, 27 BERKELEY J. GENDER L. \& JUST. 198, 214 (2012) (noting that "[m]any trans women, especially trans women of color, are profiled as sex workers and picked up for 'walking while trans' in moral sweeps by the police"); Pooja Gehi, Gendered (In)Security: Migration and Criminalization in the Security State, 35 HARV. J.L. \& GENDER 357, 368 69 (2012) (noting that transgender people are often profiled by the police as criminals even when they are not committing any crimes and that this is commonly described as "walking while trans").

145. David Harris, "Driving While Black" and All Other Traffic Offenses: The Supreme Court and Pretextual Traffic Stops, 87 J. CRIM. L. \& CRIMINOlOGY 544, 546 (1997) (noting that "the stopping of black drivers [by police officers], just to see what [they] can find, has become so common in some places that this practice has its own name: . . "driving while black"). Some black people have even experienced being profiled while walking. See Paul Butler, "Walking While Black" : Encounters with the Police on My Street, Legal Times, Nov. 10, 1997, at 23 . 
rather than a partial justification, ${ }^{146}$ the way it is deployed in trans panic cases often sounds in justification. ${ }^{147}$

A justification defense is a criminal law defense in which the defendant argues that he did the right thing. ${ }^{148}$ The justified defendant claims he acted the way that society would have wanted him to act. ${ }^{149}$ Self-defense, for example, is typically considered a justification defense. ${ }^{150}$ An individual who kills a person who is attacking him and about to kill or seriously injure him acts the way society would expect him to act.

An excuse defense, in contrast, is a criminal law defense in which the defendant admits what he did was wrong but argues he should be excused because he is not morally blameworthy for his wrongful conduct. ${ }^{151}$ Duress, for example, is an excuse defense. ${ }^{152}$ When a person commits a crime under duress, he admits that what he did was wrong but claims that he did it only because someone threatened to seriously harm him or another innocent person. ${ }^{153}$

146. See Mitchell Berman \& Ian Farrell, Provocation Manslaughter as Partial Justification and Partial Excuse, 52 WM. \& MARY L. REV. 1027, 1027-28 (2011) (“"[T]he dominant scholarly view holds that provocation is best explained and defended as a partial excuse."); Reid Griffith Fontaine, Adequate (Non)provocation and Heat of Passion As Excuse Not Justification, 43 U. Mich. J.L. REFORM 27, 32 (2009) (noting "the social cognitive argument presumes that heat of passion is a partial excuse defense"); DRESSLER, UNDERSTANDING CRIMINAL LAW, supra note 91, §§ 31.07(C)(1)-(2)(a), (b), at 508-09.

147. Lee \& Kwan, supra note 24, at 99-100 (arguing that the provocation defense "is better viewed as one that includes features of both excuse and justification"); $i d$. at 113 (noting that defendants alleging trans panic seek to blame the victim for her alleged deceit).

148. Dressler, Understanding Criminal LAw, supra note 91, § 17.02, at 198 (noting that "justified conduct is conduct that under ordinary circumstances is criminal, but which under the special circumstances encompassed by the justification defense is not wrongful and is even, perhaps, affirmatively desirable").

149. Id. ("A justified act is one that "the law does not condemn, [but] welcomes."') (citation omitted).

150. Christopher W. Behan, When Turnabout Is Fair Play: Character Evidence and Self-Defense in Homicide and Assault Cases, 86 OR. L. REV. 733, 739 (2007) ("Self-defense is a classic justification defense."); Stephanie Spies, Malice Aforethought and Self-Defense: Mutually Exclusive Mental States?, 91 N.Y.U. L. Rev. 1027, 1028 (2016) (noting that "self-defense has been an available justification to criminal defendants since the early ages of the common law").

151. DRESSLER, Understanding CRIMINAl LAw, supra note 91, § 16.04, at 195 (noting that "an excuse centers upon the actor (i.e., [the defendant]), and tries to show that the actor is not morally culpable for his wrongful conduct").

152. Steven J. Mulroy, The Duress Defense's Uncharted Terrain: Applying It to Murder, Felony Murder, and the Mentally Retarded Defendant, 43 SAN DiEgo L. REv. 159, 167 (2006) (noting that duress is considered an "excuse" defense); Peter Westen \& James Mangiafico, The Criminal Defense of Duress: A Justification, Not an Excuse - and Why It Matters, 6 BUFF. CRIM. L. REV. 833, 834-35 (2003) (stating that "[v]irtually no one argues that modern defenses of duress ... can be rationalized as a defense of justification").

153. As Wayne LaFave explains:

A person's unlawful threat (1) which causes the defendant reasonably to believe that the only way to avoid imminent death or serious bodily injury to himself or to another is to engage in conduct which violates the literal terms of the criminal law, and (2) which causes the defendant to engage in that conduct, gives the defendant the defense of duress (sometimes called compulsion or coercion) to the crime in question unless that crime consists of intentionally killing an innocent third person. 
Provocation is usually considered an excuse defense. ${ }^{154}$ When a defendant asserts a trans panic argument in support of a provocation defense, however, the provocation defense reflects elements of both justification and excuse. ${ }^{155}$ Instead of admitting that what he did was wrong, a murder defendant claiming trans panic blames the victim for his actions, arguing that the transgender victim's deceit caused him to lose self-control. ${ }^{156}$ In arguing that the average man would lose his self-control if he discovered that the person he was attracted to was a transgender female, the defendant suggests that he acted the way society expected him to act. The defendant also tries to excuse his actions, suggesting that he was simply acting under extreme circumstances, but otherwise is not a bad person.

A blame-the-victim approach was used at the trial of two men charged with murdering a transgender female teenager, Gwen (also known as Lida) Araujo, in California. ${ }^{157}$ Araujo, who was seventeen years old, ${ }^{158}$ had been sexually intimate with Jose Merel and Michael Magidson, engaging in oral and anal sex with each of them separately. ${ }^{159}$ Merel and Magidson began to suspect that Araujo was not born female when she repeatedly refused their attempts to have vaginal intercourse. ${ }^{160}$

2 Wayne R. LaFave, Substantive Criminal Law $§ 9.7$ (3d ed. 2019). The "rationale of the defense of duress is that the defendant ought to be excused when he 'is the victim of a threat that a person of reasonable moral strength could not fairly be expected to resist."' Id. (citation omitted); see also 1 NINTH CIRCUIT CRIMINAL HANDBOOK § 8.04 (2019) ("In general, a duress defense asserts that while the defendant committed the act that constitutes the offense, it should be excused because his will was overborne by threats from another person. . . [A] duress defense requires the defendant to show: (1) an immediate threat of death or serious bodily [harm]; (2) a well-founded fear that the threat would be carried out; and (3) that there was no reasonable opportunity to escape the threatened harm.").

154. Joshua Dressler, Provocation: Partial Justification or Partial Excuse?, 51 Mod. L. REv. 467, 469 (1987) (noting that the defense of provocation is usually viewed as a partial excuse).

155. LeE, Murder AND THE ReAsonable MAN, supra note 91, at 227-29 (arguing that the defense of provocation contains elements of both justification and excuse); A.J. Ashworth, The Doctrine of Provocation, 35 CAMBridge L.J. 292, 307 (1976) (arguing that the provocation defense has elements of both justification and excuse).

156. Lee \& Kwan, supra note 24 , at 113-14.

157. People v. Merel, No. A113056, 2009 WL 1314822, at *6-8 (Cal. Ct. App. May 12, 2009); see also Man Given 11 Years in Gwen Araujo's Death, L.A. Times (Aug. 26, 2006), https://www.latimes.com/archives/laxpm-2006-aug-26-me-sentence26-story.html [https://perma.cc/ZCE5-DJN3].

158. Carolyn Marshall, Two Guilty of Murder in Death of a Transgender Teenager, N.Y. TIMES (Sept. 13, 2005), https://www.nytimes.com/2005/09/13/us/two-guilty-of-murder-in-death-of-a-transgender-teenager.html [https://perma.cc/S7Z9-KQ22]; Malaika Fraley, Gwen Araujo's Murder 14 Years Later: Transgender Teen's Killers Face Parole, EAST BAY TIMES (Oct. 14, 2016), https://www.eastbaytimes.com/2016/10/14/the-murderof-gwen-araujo/ [https://perma.cc/24LV-QZUB] (“Sylvia Guerrero had never even heard the word 'transgender' until her 17-year-old daughter Gwen Araujo, born a son named Eddie, was brutally murdered.”); Man Given 11 Years in Gwen Araujo's Death, supra note 157 (noting that Araujo was seventeen years-old when she was killed).

159. Merel, 2009 WL 1314822, at*1.

160. Id. The teens had noticed Araujo had very large hands and what appeared to be an Adam's apple. They became even more suspicious that Araujo was not biologically female when they spoke with each other and found out Araujo had told one of them that she was menstruating to avoid having sexual intercourse with him, and told the other she was menstruating just two weeks later, $i d$., even though a menstrual period usually lasts less than seven days. 
One night during a party at Merel's house, ${ }^{161}$ Magidson took Araujo into the bathroom to try to confirm Araujo's biological sex. ${ }^{162}$ When Araujo told Magidson not to touch her, Magidson left the bathroom and asked a friend, Nicole Brown, to find out whether Araujo was a man or a woman. ${ }^{163}$ Brown went into the bathroom where she felt Araujo's groin area, then ran from the bathroom screaming that Araujo was a man. ${ }^{164}$ When Araujo emerged from the bathroom, Magidson put his arm around her throat and choked her. ${ }^{165}$ Merel grabbed a can of food and hit Araujo's head repeatedly with the can so hard that he dented it. ${ }^{166}$ According to the prosecution, he then left the room, came back with a frying pan, and hit Araujo again on the crown of her head. ${ }^{167}$ Magidson followed by punching and kneeing Araujo in the face; she died later that night. ${ }^{168}$

Merel and Magidson were arrested and charged with first-degree murder. ${ }^{169}$ They admitted to killing Araujo, but argued that the discovery that Araujo was biologically male provoked them into a heat of passion. ${ }^{170}$ At trial, Magidson's attorney, Michael Thorman, argued that Magidson's discovery that Araujo was biologically male and that he had unknowingly engaged in homosexual sex incited his revulsion and rage. ${ }^{171}$ Placing the blame for his client's violence on Araujo and using the name Eddie, which was the name given to Araujo at birth, rather than Araujo's preferred name, Thorman told the jury, “This crime didn't occur because Mike had a bias. It happened because of the discovery of what Eddie had done."172 Suggesting that Araujo had deceived Magidson about her sex and thus betrayed him, Thorman concluded: "This is a case . . . about . . . the tragic results when that deception and betrayal were discovered." ${ }^{\prime 73}$ The jury could not agree on a verdict, with some jurors favoring first-degree murder and others favoring second-degree

161. Id. at $* 2$.

162. John M. Glionna, Keeping Focus on Victim in Retrial, L.A. Times, July 5, 2005, at B1.

163. Id.

164. Id. (reporting that Brown felt Araujo's genitals and ran from the bathroom screaming); Merel, 2009 WL 1314822, at*3 (stating that Brown claimed she had felt Araujo and yelled that she was a man).

165. Merel, 2009 WL 1314822, at *3; see also Daisy Hernández, "She Wanted to be Normal. We Both Did": Why Gender, Sexuality, and Desire Matter, SALON (Oct. 18, 2014), https://www.salon.com/2014/10/18/ she_wanted_to_be_normal_we_both_did_why_gender_sexuality_and_desire_matter/ [https://perma.cc/4WTQ6KJK] (reporting that Magidson dragged Araujo into the living room).

166. Merel, 2009 WL 1314822, at*3.

167. Id. At trial, Merel testified that he did not hit Araujo with a frying pan. Telephone Conversation with William DuBois, Merel's attorney (Nov. 2, 2019).

168. Merel, 2009 WL 1314822, at $* 4, * 8$.

169. Id. at $* 9$. The information in the first case brought against Merel and Magidson included a hate crime allegation as well. $I d$. The jury, however, rejected the hate crime allegation "because some panelists believed that the defendants killed Araujo not necessarily because of her gender orientation, but simply to "cover up a situation that had gotten out of control." Henry K. Lee, Manslaughter Ruled Out, Araujo Juror Says, S.F. CHRON., Sept 14, 2005, at B1.

170. Yomi S. Wronge, Mistrial in Killing of Transgender Teen: Jury Deadlocks on Issue of Premeditation, SAN Jose Mercury News, June 23, 2004, at A1.

171. Vicki Haddock, 'Gay Panic' Defense in Araujo Case, S.F. Chron., May 16, 2004, at E1.

172. Id.

173. Id. 
murder, so the judge declared a mistrial. ${ }^{174}$ On retrial before a different jury, Merel and Magidson were found guilty of second-degree murder. ${ }^{175}$

\section{Motivations for the Defendant's Violence in Trans Panic Cases}

\section{a. The Defendant's Fear of Being Seen as Gay}

In a trans panic case, there are several possible motivations for the defendant's violent reaction, none of which should be seen as legally adequate to support a provocation defense. ${ }^{176}$ First, the defendant's violence may be motivated by his fear of being seen as gay. ${ }^{177}$ Angela Harris, Frank Rudy Cooper, Ann McGinley, and others in the field of masculinity studies have observed that men in our society are socialized to believe that being a man means not being a woman and not being gay. ${ }^{178}$ Since the defendant thinks the transgender woman is a man masquerading as a woman, he may feel that his being attracted to a transgender female threatens his masculine identity by exposing him as a man who likes other men and is therefore gay. ${ }^{179}$

As I have noted in the past, killing the transgender woman affirms the defendant's sense of masculinity, at least in his mind, in at least two ways. First, the defendant shows others that he is disgusted with the thought of being attracted to another man, and therefore he cannot be gay. ${ }^{180}$ Second, the defendant demonstrates his masculinity by acting with aggression and physical force, traits typically associated with masculine identity. ${ }^{181}$

174. Wronge, Mistrial in Killing of Transgender Teen, supra note 170 (noting that in Merel's case, two jurors voted in favor of first-degree murder while ten jurors voted against first-degree murder, and in Magidson's case, seven jurors voted in favor of first-degree murder and five jurors voted against first-degree murder).

175. Yomi S. Wronge, Two Found Guilty in Slaying of Teen-Mistrial Declared for Other Defendant in Transgender Case, SAN Jose Mercury News, Sept. 13, 2005, at 1A.

176. Lee \& Kwan, supra note 24 , at 108-19.

177. Id. at 109-11.

178. Angela P. Harris, Gender, Violence, Race, and Criminal Justice, 52 STAN. L. REv. 777, 786-87 (2000) (recognizing the argument of some queer theorists that in forming masculine identity, "not being a 'faggot' is as important to being a man as not being a woman"); Frank Rudy Cooper, Our First Unisex President?: Black Masculinity and Obama's Feminine Side, 86 DenV. U. L. REv. 633, 647-48 (2009) (observing that a central feature of masculinity is the need to denigrate those who are not considered masculine, i.e., women, gays, and racial minorities); Ann C. McGinley, Work, Caregiving, and Masculinities, 34 Seattle U. L. ReV. 703, 707 (2011) (noting that for many men, being a man requires proving that "one is not feminine or a girl, and that one is not gay").

179. For example, in the Dixon (Islan Nettles) case discussed above, Dixon admitted that he lashed out at Nettles only after his friends started mocking him for flirting with a transgender person. Dixon's fear of being seen as gay by his friends appears to be what provoked him to punch and kick Nettles. See supra text accompanying notes 7-8, 16-17.

180. Lee \& Kwan, supra note 24, at 110; see also Martha C. Nussbaum, "Secret Sewers of Vice," Disgust, Bodies, and the Law, in THE PASsions of LAw 19, 35-38 (Susan Bandes ed. 1999) (questioning whether "disgust at an attempted homosexual seduction provide(s) a legally adequate basis for mitigation" from murder to manslaughter).

181. Lee \& Kwan, supra note 24, at 110 (noting that some men demonstrate their masculinity by exhibiting physical strength and aggression). 
The Islan Nettles case discussed in the Introduction illustrates this "fear of being seen as gay" motivation. Recall that James Dixon was initially attracted to Nettles, crossing the street to ask her for her name. ${ }^{182}$ Only after he heard his friends mocking him for flirting with a "guy" did Dixon attack Nettles, beating her with such force that her face was battered beyond recognition. ${ }^{183}$

The "fear of being gay" motivation was also present in the Gwen Araujo case discussed above. ${ }^{184}$ Jose Merel's attorney presented testimony at trial suggesting that Merel became upset when he first started suspecting Araujo might have been born male and thought his sexual attraction to this person who might be biologically male meant he was gay. ${ }^{185}$ When his suspicions were confirmed at the party, Merel's initial reaction was to vomit and then cry. ${ }^{186}$ When his brother and a friend tried to console him, Merel kept saying that he couldn't believe he was gay. ${ }^{187}$ According to Merel's attorney, Merel was quite fond of Araujo and had developed a romantic attachment to her. ${ }^{188}$ When he discovered that Araujo was biologically male, Merel experienced a "crisis of self-conception." 189 Finding out that his love interest had a penis made him doubt his own masculinity and heterosexuality. ${ }^{190}$

In another case, a man named Paul Moore killed a seventeen-year-old transgender woman named Nireah Johnson after discovering that she was born male. ${ }^{191}$ Johnson and her friend, Brandie Coleman, met Moore and his friend, Curtis Ward, at a gas station parking lot. ${ }^{192}$ Johnson and Moore spoke briefly and exchanged phone numbers. ${ }^{193}$ Moore allowed Johnson to hug and kiss him on the cheek during this encounter. ${ }^{194}$

182. See supra text accompanying note 2 .

183. See supra text accompanying notes $4-5$.

184. See supra text accompanying notes 157-75.

185. People v. Merel, No. A113056, 2009 WL 1314822, at*2, *6 (Cal. Ct. App. May 12, 2009).

186. Id. at $* 7$.

187. $I d$. at $* 6$.

188. William H. DuBois, Criminal Defense Att'y, Remarks at University of California-Hastings College of the Law Symposium on Hate Crimes: Combating Gay \& Transgender "Panic" Strategies (July 20-21, 2006). The author was a speaker at this Symposium and attended the panel at which Bill DuBois, Merel's attorney, and Michael Thorman, Magidson's attorney, spoke; see also Zak Szymanski, DA Convenes 'Panic' Conference, BAY AREA REP. (July 26, 2006), https://www.ebar.com/news///237163.

189. Id.; see also Telephone Conversation with William DuBois, Criminal Defense Att'y, November (Nov. 2, 2019) (confirming that, at Merel's second trial, DuBois argued that Merel experienced a "crisis of selfconception" when he realized Araujo was born male); Szymanski, supra note 188 (DuBois stating that his client "experienced a personal crisis"). In his motion for a new trial on behalf of Merel, DuBois argued that his client "acted rashly, from passion and not from reason" and that "Merel was caused by that passion to question his entire self-concept. His passion was provoked by the deceased's fraudulent and felonious conduct in sexually deceiving him into committing sodomy." See Notice of Motion and Motion for New Trial, People v. Merel, No. 134583 (Cal. App. Dep't Super. Ct. Jan. 5, 2006) (on file with author).

190. Lee \& Kwan, supra note 24, at 111.

191. See Moore v. State, 827 N.E.2d 631 (Ind. Ct. App. 2005).

192. Id. at 634.

193. Id.

194. Id. 
Three days later, around 12:51 a.m., Johnson and Coleman visited the men at Moore's home. ${ }^{195}$ It is not clear why, but Moore had begun to suspect that Johnson was not born female. ${ }^{196}$ Before going out to meet Johnson and Coleman in the living room, Moore, irate, upset, and holding a handgun, asked Ward whether "Nireah (Johnson) [was] a man or a female."197 Ward told Moore that Johnson "looked like a woman to him." 198 This response did not satisfy Moore, who went out to the living room and proceeded to interrogate Johnson about her biological sex for forty minutes. ${ }^{199}$

When Johnson went to use the bathroom, Moore followed her and discovered that she was biologically male. ${ }^{200}$ Remarking "[m]an, this is a boy," Moore told his friend Ward that his manhood had been violated because Johnson had kissed him. ${ }^{201}$ Moore then asked Johnson, "What did you think, I was a faggot?"202

Moore and Ward tied Johnson's and her friend Coleman's hands behind their backs with some wire. ${ }^{203}$ Moore put Johnson and Coleman in the back of his Jeep and drove to a small park where he shot and killed them. ${ }^{204} \mathrm{He}$ then set fire to the Jeep with the two women inside to try to "cover his tracks.",205

Moore's comment, "What did you think, I was a faggot?," shows that he feared others, including Ward, might think he was gay. By killing Johnson, Moore could demonstrate his masculinity and show Ward not only that he was not gay but also that he was disgusted with the thought of having been attracted to Johnson once he discovered that she was biologically male. Acting with brutal physical force was another way Moore could demonstrate his masculine identity.

\section{b. Enforcement of Gender Norms}

The defendant who kills a transgender woman after discovering that she is biologically male may also be motivated by an extreme discomfort with gender nonconformity. ${ }^{206}$ His act of killing may reflect his desire to enforce prevailing gender norms that align sex with gender and masculine identity with heterosexual

195. Id. at 635 .

196. Id.

197. $I d$.

198. Id.

199. Id.

200. Id.

201. Id.

202. Id.

203. Id.

204. Id.

205. Id. Moore was charged with two counts of murder, two counts of felony criminal confinement, and one count of felony arson. $I d$. at 636 . After a jury trial, he was found guilty as charged and sentenced to 120 years in prison. Id. He appealed his conviction and sentence, but the Court of Appeals affirmed both his conviction and sentence. $I d$. at 641,643 (concluding that "the State presented sufficient evidence from which a jury could find Moore guilty beyond a reasonable doubt" and that the 120-year sentence was not inappropriate "given his coldblooded execution and subsequent burning of the victims").

206. Lee \& Kwan, supra note 24, at 111. 
orientation. ${ }^{207}$ As Aaron Norton and Gregory Herek explain, “[T]ransgender identities pose a challenge to the widespread assumptions that gender and biological sex are binary categories[.]"208 "Most people assume that a person born with male genitalia is a man and a person born with female genitalia is a woman."209 Norton and Herek note that transgender individuals disrupt the "stability of both gender and sexual orientation categories[.]" ${ }^{\prime 210}$ Even though the transgender woman who enjoys sex with men is heterosexual, the defendant sees her as a gay man because she is biologically male.

A number of studies suggest that men who self-identify as heterosexual are less positive towards gay men and homosexuality in general when they feel their masculine identity is under threat. For example, in one study, heterosexual men who were falsely informed that their personality test scores were more typical to those of women than those of other men expressed more negative views of homosexuality than men who had not been so informed. ${ }^{211}$ In another study, heterosexual men who were told that their personalities were significantly less masculine than the average man's personality exhibited higher levels of aggression toward a gay work partner than heterosexual men who were told their personalities were about the same as the average man's personality. ${ }^{212}$

Given these studies, it is likely that men who self-identify as heterosexual and kill trans women with whom they have been sexually intimate do so in part to restore their sense of masculinity. For example, in one case, a thirty-two-year-old man named Allen Andrade killed an eighteen-year-old transgender woman named Angie Zapata and claimed he was provoked into a heat of passion after learning that Zapata was biologically male. ${ }^{213}$ Andrade met Zapata on an online dating

207. Id.

208. Id. (quoting Aaron T. Norton \& Gregory M. Herek, Heterosexuals' Attitudes Toward Transgender People: Findings from a National Probability Sample of U.S. Adults, 68 SEX RoLES 738, 740 (2012)).

209. Lee \& Kwan, supra note 24, at 111; see also Francisco Valdes, Queers, Sissies, Dykes, and Tomboys: Deconstructing the Conflation of "Sex," "Gender," and "Sexual Orientation" in Euro-American Law and Society, 83 CALIF. L. REV. 1, 20 (1995) (noting that "[t]he first common (mis)understanding . . is the equation of sex ... with 'penis' or 'vagina'”).

210. Aaron T. Norton \& Gregory M. Herek, Heterosexuals' Attitudes Toward Transgender People: Findings from a National Probability Sample of U.S. Adults, 68 SEX ROLES 738, 741 (2012).

211. Robb Willer, Overdoing Gender: A Test of the Masculine Overcompensation Thesis, 118 AM. J. Soc. 980, 993 (2013). Similarly, in another study, men who were falsely told that their personalities were more feminine than average expressed less positive attitudes towards feminine gay men than men who were told their personalities were in line with the average male personality. See Peter Glick et al., Defensive Reactions to Masculinity Threat: More Negative Affect Toward Effeminate (But Not Masculine) Gay Men, 57 SEX RoLES 55, 57 (2007).

212. See Amelia Talley \& B. Ann Bettencourt, Evaluations and Aggression Directed at a Gay Male Target: The Role of Threat and Antigay Prejudice, 38 J. APPLIED SOC. PSYCHOL. 647, 674 (2008).

213. Valerie Richardson, Man Gets Life in Transgender Teen's Death, WASH. TIMES (Apr. 23, 2009), https:// m.washingtontimes.com/news/2009/apr/23/man-gets-life-in-transgender-teens-death/ [https://perma.cc/QN47NSKX]. 
site. $^{214}$ Zapata invited Andrade to her apartment where they spent a few days together. ${ }^{215}$ When Zapata left the apartment, Andrade began looking at her photographs, which made him question whether Zapata was a woman. ${ }^{216}$ When Zapata returned, Andrade confronted her, asking if she was really a woman. ${ }^{217}$

Andrade claimed that upon discovering that Zapata, with whom he had engaged in oral sex the night before, was biologically male, he flew into a rage. ${ }^{218}$ Andrade hit Zapata several times with a fire extinguisher, killing her. ${ }^{219}$ Andrade later told his girlfriend that Zapata was gay and "all gay things need to die," demonstrating that he saw Zapata as a gay man. ${ }^{220}$

Referencing the male first name Zapata had been given at birth, Andrade's attorney told the jury during opening statements, "When [Allen] learned Angie was in fact Justin and was a male, he immediately reacted to that." ${ }^{221}$ Echoing the trope of the deceitful transgender individual, Andrade's attorney continued, "[Allen] had been deceived and he reacted." 222

Invoking the notion of trans panic, Andrade's attorney told the jury that only after grabbing Zapata's crotch did Andrade discover the truth about Zapata's biological sex. ${ }^{223}$ Then, he continued, when Zapata smiled at Andrade and said, "I'm all woman," this caused Andrade to snap and commit murder. ${ }^{224}$ Andrade's attorney further argued that any reasonable man in Andrade's shoes would have been provoked into a heat of passion, arguing that "[w]hen (Zapata) smiled at him, this was a highly provoking act, and it would cause someone to have an aggressive reaction." 225 Because Andrade was provoked into a heat of passion by the discovery that Zapata was biologically male, Andrade's attorney implored the jury to reduce the charge from first-degree to second-degree murder. ${ }^{226}$

The jury, however, was not persuaded by the defense claim of trans panic, and found Andrade guilty of first-degree murder and a hate crime. ${ }^{227}$ Because the case

214. Jim Spellman, Transgender Murder, Hate Crime Conviction a First, CNN (Apr. 23, 2009), http://www. cnn.com/2009/CRIME/04/22/transgender.slaying.trial/index.html [https://perma.cc/S3TT-LUSD].

215. Id.

216. Id.

217. Id.

218. See Monte Whaley, Smile Called "Provoking Act" in Transgender Case, Denver Post (Sept. 28, 2008) ("Allen Andrade told his girlfriend that he 'snapped' when he learned the woman he had oral sex with the night before was biologically a man.”), https://www.denverpost.com/2008/09/18/smile-called-provoking-act-intransgender-case/ [https://perma.cc/YG23-CNLF].

219. Id.

220. Id.

221. Richardson, supra note 213.

222. Id.

223. Whaley, supra note 218. Prosecutor Robb Miller, however, argued that Andrade knew Zapata was biologically male and planned to kill her shortly after meeting her on a dating site frequented by gay, bisexual, and transgender singles. Richardson, supra note 213.

224. Whaley, supra note 218.

225. Id

226. Spellman, supra note 214; Whaley, supra note 218.

227. Richardson, supra note 213. 
was the first time a hate crime statute was successfully applied to a murder case involving a transgender victim, it was seen as a landmark decision. ${ }^{228}$ While all fifty states have enacted hate crime statutes, only twenty-one states plus the District of Columbia include gender identity, gender expression, transgender identity, or perceived sex or gender as protected categories. ${ }^{229}$ In jurisdictions that consider transgender identity a protected class, recognizing the trans panic defense arguably "runs afoul of the premise and purpose of hate crimes statutes that seek to enhance punishment for just such a motivation."230

The transgender woman transgresses norms of gender by claiming a female identity when she was considered male at birth. ${ }^{231}$ The defendant punishes this transgression by killing her. ${ }^{232}$ The law, however, generally disapproves of acts of violence, such as bullying, that are motivated by a desire to enforce gender norms. ${ }^{233}$ Likewise, the law of provocation should not approve the use of violence to enforce gender norms by allowing a defendant to claim trans panic as legally adequate provocation. ${ }^{234}$

\section{c. The Defendant's Belief that the Transgender Victim was Being Deceitful}

Finally, the defendant's violence may be motivated by a belief that in not disclosing her biological sex, the transgender female victim was being deceitful about her "true" gender identity. ${ }^{235}$ The belief that transgender individuals are deceitful is widespread. As Dean Spade ${ }^{236}$ notes, "[t]he myth that birth-assigned gender is the only gender identity that can be recognized ... motivates judicial decisions in

228. Commenting on the fact that Andrade was found guilty of both first-degree murder and a hate crime for killing a transgender person, Mindy Barton, Legal Director for the Gay, Lesbian, Bisexual and Transgender Community Center of Colorado, noted, "This is a landmark decision." Spellman, supra note 214.

229. See infra Appendix (listing the states that include gender identity or expression, transgender identity, or perceived sex or gender as protected categories in their hate crime statutes). As noted in the Appendix, while use of "perceived gender" language in a hate crime statute arguably covers transgender individuals who are targeted because their perceived gender does not match their biological sex, it is unclear whether courts in three of these states (Louisiana, Mississippi, and Rhode Island) would interpret this "perceived gender" language to cover transgender victims.

230. Scott D. McCoy, Note, The Homosexual-Advance Defense and Hate Crimes Statutes: Their Interaction and Conflict, 22 CARDozo L. REv. 629, 634 (2001) ("In the case of the homosexual-advance defense, where the motivation behind the criminal act is inseparable from and grounded in the actor's homophobia, allowing the actor's homophobia to excuse his conduct partially and thereby mitigate punishment runs afoul of the premise and purpose of hate crimes statutes that seek to enhance punishment for just such a motivation.”).

231. Lee \& Kwan, supra note 24, at 112.

232. Id.

233. Id. at $112-13$.

234. Id. at 113 .

235. Id. at 113 n.206.

236. Dean Spade, who founded the Sylvia Rivera Law Project, a non-profit law collective that provides free legal services to transgender, intersex, and gender non-conforming people who are low-income and/or people of color, is an Associate Professor of Law at Seattle University School of Law. He may be the first transgender person to get a tenure-track law professor job. Dean Spade, Be Professional!, 33 HARV. J.L. \& GENDER 71, 71 (2010) ("I am perhaps the first transgender person to get a tenure-track law professor job, or at least no one seems to know of any others[.]"). 
which courts deny legal name changes to transgender people based on the assertion that such a name change may allow the [transgender individual] to engage in fraud." 237 Spade observes that "[ $\mathrm{t}]$ his belief that transgender people's gender identities are fraudulent or false . . is based in a fundamental notion that birth-assigned gender is the only 'true' gender an individual can have and that transgender identity is not recognizable or legitimate." 238

Implicit in the trans panic defense strategy is the idea that the transgender victim was culpably deceitful and wrongfully misled the defendant into thinking she was a woman when she was really a man, thus provoking him into a heat of passion. ${ }^{239}$ For example, in the Allen Andrade (Angie Zapata) case discussed above, ${ }^{240}$ Andrade's attorney argued that Andrade "had been deceived." 241 Similarly, in the Gwen Araujo case, Magidson's attorney argued that the case was about "the tragic results when [Araujo's] deception and betrayal were discovered." 242

Jurors should reject the idea that a transgender woman is being deceitful by not disclosing her biological sex. In cases involving transgender female victims who had not yet undertaken sex-reassignment surgery, the defendant should have seen signs that the victim was transitioning from male to female, so any claim that the victim was trying to hide her biological sex should be viewed with skepticism. ${ }^{243}$ Even a transgender woman who has fully transitioned may have legitimate reasons for not disclosing her biological sex to others. For instance, she may fear that revealing her biological sex will lead to violence. ${ }^{244}$

Morgan Tilleman explains another reason why the suggestion that a transgender woman who fails to disclose her biological sex is engaging in sexual deception is problematic. Tilleman notes that "[t]he claim of fraud presupposes the existence of

237. Dean Spade, Trans Formation: Three Myths Regarding Transgender Identity Have Led to Conflicting Laws and Policies that Adversely Affect Transgender People, 31 L.A. LAWYER 34, 36 (Oct. 2008).

238. Id.

239. Kate Greenberg provides examples of how trans women and gender-nonconforming women are depicted as fraudulent and deceitful in film and television. Greenberg, supra note 144, at 210-11; see also JOEY L. MOGUL et AL., Queer (In)Justice: The Criminalization of LGBT People in the United States 73, 76 (2011) (discussing the trope of the deceptive transgender individual reflected in past criminal statutes that prohibited cross-dressing as well as comments by judges and prosecutors in criminal cases). For additional examples, see Lee \& Kwan, supra note 24, at 113 n.206.

240. See supra text accompanying notes 213-26.

241. See supra text accompanying note 221-22.

242. See supra text accompanying note 173 .

243. Lee \& Kwan, supra note 24, at 114. In the Allen Andrade (Angie Zapata) case discussed above, the prosecutor told jurors Andrade knew in advance that Zapata was a transgender woman because he accompanied her to a court hearing where she was called by her birth name, Justin. See Ernest Luning, Prosecutor: Accused Zapata Killer Didn't 'Snap' At Transgender 'Deception', Colo. InDEP. (Apr. 17, 2009), https://www. coloradoindependent.com/2009/04/17/prosecutor-accused-zapata-killer-didnt-snap-at-transgender-deception/ [https://perma.cc/4T3C-6BE4].

244. See Janet Mock, Redefining Realness: My Path to Womanhood, Identity, Love \& So Much MORE 159-61 (2014). 
a 'material fact that one has a duty to reveal.",245 Tilleman continues, "A person's anatomical sex is not a material fact capable of being misrepresented in most sexual relationships, including those which give rise to assertions of the trans panic defense." 246 This is because "[e]ither the transgender person's genitals are irrelevant to the sexual act or acts that do occur, or the transgender person's genitals are exposed to his or her sexual partner in the course of sex acts." 247

\section{Why Legislative Action Limiting the Trans Panic Defense Strategy is NEEDED}

Not long ago, I was reluctant to support legislation banning gay and trans panic defense strategies. In previous scholarship, I wrote about how gay and trans panic defense strategies are reprehensible attempts to capitalize on stereotypes about LGBTQ $^{248}$ (lesbian, gay, bisexual, transgender, and queer) individuals as sexual deviants. ${ }^{249}$ However, as a former criminal defense attorney concerned about placing restrictions on a defendant's right to present a defense, I expressed reasons to be cautious before embracing legislative bans on the use of gay or trans panic defense strategies. ${ }^{250}$

245. Morgan Tilleman, (Trans)forming the Provocation Defense, 100 J. CRIM. L. \& CRIMINOLOGY 1659, 1678 (2010) (citation omitted).

246. Id. at $1678-79$.

247. Id. (noting that "[i]n neither the Zapata nor the Araujo case was there genital-to-genital contact or even exposure of the transgender [victim's] genitals"). Tilleman notes that "the anatomical sex of an oral sex partner, for example, is immaterial to the contemplated sex act." Id. at 1679.

248. Some prefer the acronym LGBTQIAP + , which stands for lesbian, gay, bisexual, transgender, queer, intersex, asexual, polysexual or pansexual, and others. See LuCA PAX, QueER Asterik, LGBTQIAP+ EtiQuette Guide And Glossary Of Terms (2016, 2017), www.queerasterisk.com.

249. See Lee, The Gay Panic Defense, supra note 106, at 476 (arguing that gay panic defense strategies "are problematic because they reinforce and promote negative stereotypes about gay men as sexual deviants and sexual predators"); Lee, Masculinity on Trial, supra note 117, at 817-18 (noting that gay and trans panic defenses "seek to capitalize on conscious and unconscious bias against gay and trans individuals" and "reinforce negative stereotypes about gay men and other gender-nonconforming individuals"); Lee \& Kwan, supra note 24, at 119 (noting that the "trans panic defense strategy is problematic because it reifies structures of masculinity and reinforces negative[] stereotypes about transgender individuals as sexual deviants").

250. Lee, The Gay Panic Defense, supra note 106, at 522-57 (articulating three broad frameworks to "illustrate why allowing defendants to argue gay panic better serves the dual purposes of ensuring a fair trial to the defendant and achieving the ends of justice that the State seeks" than precluding such arguments through a legislative ban); Lee \& Kwan, supra note 24, at 123 (arguing "it is critical to combat the underlying structures of masculinity that encourage violence against transgender females in the first place to both reduce the risk of such violence taking place and undermine the effectiveness of the trans panic defense strategy"). Some have mischaracterized my work. For example, in 2013, David Allan Perkiss suggested that I think gay panic is a "legitimate" defense. See, e.g., David Alan Perkiss, A New Strategy for Neutralizing the Gay Panic Defense at Trial: Lessons from the Lawrence King Case, 60 UCLA L. REV. 778, 812 (2013) (stating that "[i]mplicitly, Lee recognizes that gay panic may arguably be a legitimate source of adequate provocation[,]" and arguing that "[t]he general position ... that gay panic is legitimate as a legal defense has three major flaws"). I have always been clear that I believe the use of gay and trans panic defense strategies is problematic and that the discovery that one's intimate partner is a transgender female should not be recognized as legally adequate provocation). See Lee, The Gay Panic Defense, supra note 106, at 476 (arguing that gay panic defense strategies are "problematic because they reinforce and promote negative stereotypes about gay men as sexual deviants and sexual 
Instead of banning these defense strategies, I proposed a tool kit of strategies for prosecutors to combat gay and trans panic arguments. ${ }^{251}$ In large part, my resistance to legislative bans on the gay and trans panic defenses was based on the assumption that if the prosecutor simply educated jurors about what it means to be a transgender person, humanized the transgender female victim, and made the bias against transgender individuals that is so deeply rooted in our society salient, jurors would do the right thing and reject the trans panic defense. ${ }^{252}$ I now realize that education is necessary but not sufficient to change attitudes and behavior. ${ }^{253}$ In this Part, I first explain my shift in position. I then examine possible objections to legislatively banning the trans panic defense.

\section{A. Explaining the Shift in My Position}

My past position was influenced in large part by empirical research showing that when attorneys ignore the role of racial stereotypes and fail to make race salient in cases involving a risk of racial bias, jurors tend to be more punitive towards black defendants than white defendants, all else being equal. ${ }^{254}$ This empirical research also demonstrates that if attorneys concerned about racial bias make the operation of racial stereotypes salient to jurors, jurors tend to treat similarly situated black and white defendants the same. ${ }^{255}$ Given this extensive research on race salience, I believed that if prosecutors concerned about bias against transgender individuals made the existence of such bias salient to jurors, jurors would treat the transgender

predators"); id. at 555 (opining that gay panic arguments are "reprehensible"); Lee \& Kwan, supra note 24, at 108-19 (providing reasons why jurors should reject the trans panic defense).

251. See Lee, The Gay Panic Defense, supra note 106, at 559-66 (suggesting questions that a prosecutor can ask during jury selection to ferret out bias on the basis of sexual orientation and suggesting that prosecutors make sexual orientation bias salient through gender and sexual orientation switching); Lee \& Kwan, supra note 24, at 123 (arguing that " $[\mathrm{t}]$ he prosecutor should try to educate jurors about what it means to be a transgender woman and why disclosure may have been difficult for the victim"); id. at 126-27 (arguing that "the prosecutor can seek to proffer expert witness testimony about the cultural structures of masculinity that may have contributed to the defendant's violent acts"); id. at 127 (suggesting that prosecutors relabel the defense strategy by calling it "trans rage," which suggests the defendant was acting out of anger and rage, rather than "trans panic," which suggests the defendant panicked and lost his self-control).

252. Lee \& Kwan, supra note 24, at 123-25. We also argued that instead of equating reasonableness with typicality, the reasonableness requirement "should be understood as a normative limitation on the provocation doctrine." Id. at 125 .

253. Here, I borrow from Amitha Kalaichandran who, in arguing for legislation requiring all cars to be equipped with a child safety alert system to prevent the deaths of children in hot cars, stated, "[o]ne of the biggest lessons I learned a decade ago in public-health graduate school was that education was rarely enough, on its own, to fundamentally change behavior. Educating the public about health was "necessary but not sufficient[.]", Amitha Kalaichandran, Preventing Deaths in Hot Cars, WASH. Post, Aug. 15, 2019, at A17.

254. Lee, The Gay Panic Defense, supra note 106, at 543-49.

255. Samuel R. Sommers \& Phoebe C. Ellsworth, White Juror Bias: An Investigation of Prejudice Against Black Defendants in the American Courtroom, 7 Psychol. PuB. Pol'y \& L. 201, 217 (2001); Samuel R. Sommers \& Phoebe C. Ellsworth, Race in the Courtroom: Perceptions of Guilt and Dispositional Attributions, 26 Personality \& Soc. Psychol. Bull. 1367, 1373-74 (2000). 
victim the same as they would a non-transgender victim and would reject the trans panic defense.

Making race salient, however, works to reduce discrimination against black people by jurors who endorse racially egalitarian principles. ${ }^{256}$ When race is made salient, jurors are reminded of their egalitarian principles and may then consciously try not to let racial stereotypes influence their decision making, leading to fairer treatment of black and white defendants. ${ }^{257}$ When race is ignored, implicit racial bias leads these jurors to act in racially discriminatory ways without realizing that they are doing so.

In contrast to individuals with implicit racial bias who embrace racially egalitarian principles, many individuals with bias against transgender individuals are not just implicitly biased against transgender individuals. These individuals are often conscious of their negative views of transgender individuals and embrace those views. ${ }^{258}$ In other words, they are explicitly biased against transgender individuals.

The Trump Administration's embrace of trans-hostile policies, ${ }^{259}$ including but not limited to Trump's ban on allowing transgender individuals to serve in the

256. Patricia Devine, Stereotypes and Prejudice: Their Automatic and Controlled Components, $56 \mathrm{~J}$. PERSONALITY \& SOC. PSYCHOL. 5, 14 (1989) (finding that when racial stereotypes about black people were made salient, low-prejudice individuals tried to align their thoughts about black people with their egalitarian beliefs about black people). While most Americans today are implicitly biased in favor of white people and against black people, they embrace egalitarian principles when it comes to race, sincerely believing that black people and white people should be treated equally. See Maria Krysan \& SARAH Moberg, Univ. Of Ill. InStit. Gov'T \& Pub. AfFairs, Trends IN Racial AtTitudes (Aug. 25, 2016), https://igpa.uillinois.edu/programs/racialattitudes [https://perma.cc/RQ7C-JRUV] (noting that "survey questions that tap attitudes toward the principle of equality are no longer included on major national surveys [because] they have become essentially universally accepted by white people and therefore not deemed as worth asking on surveys"); IPSOS PUB. AFF., REUTERS/ IPSOS/UVA CENTER FOR POLITICS RACE POLL (Sept. 11, 2017), http://www.centerforpolitics.org/crystalball/wpcontent/uploads/2017/09/2017-Reuters-UVA-Ipsos-Race-Poll-9-11-2017.pdf (estimating that 80\% of Americans polled strongly agreed that all races should be treated equally); see also Rachel D. Godsil, Answering the Diversity Mandate, 286 N.J. LAw. 44, 45 (2014) (noting that most Americans, and undoubtedly most lawyers, subscribe consciously to the norm that people deserve equal treatment regardless of race, and that racial integration is a desirable goal); Cynthia Lee, Making Race Salient: Trayvon Martin and Implicit Bias in a Not Yet Post-Racial Society, 91 N.C. L. REV. 1557, 1570 (2013) ("By and large, Americans embrace the egalitarian race norms that are enunciated in the Equal Protection Clause of the Fourteenth Amendment."); Dayna Bowen Matthew, Health Care, Title VI, and Racism's New Normal, 6 Geo. J.L. \& Mod. CRitical RaCe PersP. 3, 37 (2014) (noting that most Americans act in accord with their implicit biases, even if these attitudes are directly contrary to their expressly egalitarian views on race).

257. Devine, supra note 256, at 14.

258. For example, many Americans believe men shouldn't wear makeup or dress in women's clothing. Paul Hiebert, America Isn't Ready For Men in Makeup, YouGov (Nov. 1, 2016), https://today.yougov.com/topics/ lifestyle/articles-reports/2016/11/01/males-wear-makeup [https://perma.cc/M2BQ-3Q5R] (noting that most Americans are not comfortable with men wearing mascara or nail polish); Terri Lee Ryan, The Cross-Dresser's Challenge for Acceptance, HuFFPost (July 7, 2015), https://www.huffpost.com/entry/the-crossdresserschallen_b_7715416 [https://perma.cc/93GR-WYEN] (noting that many cross-dressers fear they will lose their jobs if their employers or clients find out they wear women's clothing).

259. During the 2016 presidential campaign, candidate Donald Trump spoke and acted as if he would be a friend to the transgender community if elected to office. For example, in April 2016, Trump said he supported the right of transgender people to "use the bathroom that they feel is appropriate," and added that Caitlyn Jenner, a transgender female celebrity, could use whichever bathroom she wanted to use at Trump Tower. See Helena 


\section{military $^{260}$ and his rollback of Obama-era protections for transgender students}

Andrews-Dyer, Donald Trump says Caitlyn Jenner Can Use Whatever Bathroom She Wants at Trump Tower, WASH. PoST (Apr. 21, 2016), https://www.washingtonpost.com/news/reliable-source/wp/2016/04/21/donaldtrump-says-caitlyn-jenner-can-use-whatever-bathroom-she-wants-at-trump-tower/ [https://perma.cc/XE2ZMXRM]. After becoming President, however, Trump and his Administration made several moves to roll back many of the civil rights protections that transgender individuals had achieved under the Obama Administration. In October 2017, then U.S. Attorney General Jeff Sessions announced the Department of Justice's decision to end an Obama-era policy that had protected transgender workers from employment discrimination through Title VII. See Sari Horwitz \& Spencer S. Hsu, Sessions Ends Transgender Protection, WASH. Post, Oct. 6, 2017, at A3. In June 2019, the U.S. State Department instructed U.S. embassies across the world not to display the rainbow flag on any public-facing flagpole. See Frida Ghitis, How Trump is Abandoning LGBTQ People Over Pride flags, CNN (June 11, 2019), https://www.cnn.com/2019/06/11/opinions/trump-pride-month-flag-opinionghitis/index.html [https://perma.cc/YVZ4-QC89]; Ernesto Londono, Pride Flags and Foreign Policy: U.S. Diplomats See Shift on Gay Rights, N.Y. TIMES (June 9, 2019), https://www.nytimes.com/2019/06/09/world/ americas/pride-flags-us-embassies.html [https://perma.cc/RCX6-HL8P].

The Trump Administration has also attempted to reverse Obama-era policies prohibiting discrimination on the basis of gender identity under the Affordable Care Act ("ACA"). See Michael Ollove, States are All Over the Map When it Comes to Transgender Reassignment Care, WASH. Post, July 23, 2019, at E6. Under the Obama Administration, "[s]ervices deemed medically necessary for some patients, such as mastectomies for women with breast cancer, [could not] be denied to others, such as transitioning transgender patients with gender dysphoria." Id. The ACA was also interpreted to mean that medical providers could not "deny medical services to [an individual] just because that individual [was] transgender." Id. In May 2019, the Trump Administration issued regulations enhancing protections for medical providers that refuse to provide care for transgender individuals for religious reasons. Id. In June 2019, the Trump Administration proposed overturning the abovedescribed Obama-era policies prohibiting discrimination on the basis of gender identity under the Affordable Care Act. Id. Additionally, in the spring of 2017, the U.S. Department of Health \& Human Services (HHS) issued a memorandum that indicated it was considering a proposal to redefine "sex" under Title IX as "a person's status as male or female based on immutable biological traits identifiable by or before birth." See Erica L. Green et al., 'Transgender' Could Be Defined Out of Existence Under Trump Administration, N.Y. TIMEs (Oct. 21, 2018), https://www.nytimes.com/2018/10/21/us/politics/transgender-trump-administration-sex-definition.html [https:// perma.cc/AR2X-XBG9].

260. Trump first announced his intention to ban transgender individuals from the military in three consecutive tweets on July 26, 2017, writing, "After consultation with my Generals and military experts, please be advised that the United States Government will not accept or allow ... [t]ransgender individuals to serve in any capacity in the U.S. Military. Our military must be focused on decisive and overwhelming . . victory and cannot be burdened with the tremendous medical costs and disruption that transgender (sic) in the military would entail. Thank you[.]" See Donald Trump (@realDonaldTrump), TwITTER (July 26, 2017, 8:55-9:08 AM), https:// twitter.com/realDonaldTrump/status/890193981585444864?ref_src=twsrc\%5Etfw\%7Ctwcamp\%5Etweetembed \%7Ctwterm\%5E890193981585444864\&ref_url=https\%3A\%2F\%2Fwww.theatlantic.com\%2Fpolitics\%2Farchive $\% 2 \mathrm{~F} 2019 \% 2 \mathrm{~F} 01 \% 2 \mathrm{Fdonald}-t$ rump-tweets-transgender-military-service-ban\%2F579655\%2F [https://perma.cc/ 8ZVG-TL8L]; Matt Thompson, How to Spark Panic and Confusion in Three Tweets: Do Impulsive Twitter Messages from the President Count as Formal Policy Action?, AtLANTIC (Jan. 13, 2019), https://www. theatlantic.com/politics/archive/2019/01/donald-trump-tweets-transgender-military-service-ban/579655/ [https:// perma.cc/7F9B-ZTJF]; see also Steven Petrow, An Attack by Trump on LGBT Community, WASH. Post, July 27, 2017, at C1. Later, Trump issued an updated order banning most transgender individuals from serving in the military. See Memorandum from President Donald J. Trump to Sec'y of Def. James Mattis and Sec'y of Homeland Sec. Kirstjen Nielsen Regarding Military Service by Transgender Individuals (Mar. 23, 2018), https://www. whitehouse.gov/presidential-actions/presidential-memorandum-secretary-defense-secretary-homeland-securityregarding-military-service-transgender-individuals/ [https://perma.cc/2H2B-KYR9].

In contrast to the absolute ban on all transgender individuals serving in the military that he had announced earlier by tweet, Trump's revised policy allows transgender service members who have not undergone gender reassignment surgery to stay in the military, as long as they have been stable for thirty-six consecutive months in their biological sex before joining the military. See Dan Lamothe, Trump Eases Transgender Service Ban 
seeking to use the bathroom corresponding to their gender identity, ${ }^{261}$ has revealed an ugly truth about American society. A significant number of Americans today do not see trans people as normal human beings deserving of equal treatment, and many of these Americans feel some degree of hostility towards trans people. ${ }^{262}$ Many of those who are explicitly biased against transgender persons have become emboldened by the current Administration's trans-hostile policies to express their hostility openly and without fear of societal repercussion. There is some evidence of this in the recent spike in hate violence against transgender individuals, ${ }^{263}$ but it

Slightly: Order Revokes Full Prohibition but Bars Many From Serving, WASH. PosT, Mar. 24, 2018, at A1. In other words, transgender individuals may serve as long as they give up their gender identity and embrace their biological sex with one exception: transgender service members who were diagnosed with gender dysphoria after the Obama Administration ended the ban on transgender troops in 2016, but before implementation of the Trump ban in 2018, may continue to serve in the military in their chosen gender identity. Id. In January 2019, the U.S. Supreme Court decided to allow Trump's restrictions on transgender individuals serving in the military to go into effect while the lawsuits against these restrictions continue in the lower courts. See Robert Barnes \& Dan Lamothe, Supreme Court Lets Trump's Restrictions on Transgender Troops Take Effect, WASH. Post, Jan. 23, 2019, at A4. Two months later, the Pentagon announced that the military would begin enforcing President Trump's restrictions on transgender troops in the military on April 12, 2019. See Paul Sonne \& Ann E. Marimow, Transgender Troop Policy to be Enforced April 12, WASH. PosT, Mar. 14, 2019, at A2.

261. Less than two months after taking office, the Trump Administration rescinded Obama-era protections for transgender students seeking to use the bathroom corresponding to their gender identity. See Erica L. Green, L.G. B.T.Q. Students' Rights Cases Stall Under DeVos, Report Finds, N.Y. Times (July 30, 2019), https://www. nytimes.com/2019/07/29/us/politics/gay-transgender-rights-devos.html [https://perma.cc/Z2QR-2SPR] (noting that "[i]n 2017, just weeks after the new administration took office, the Education and Justice Departments rescinded an Obama-era guidance document that informed schools that denying students access to bathrooms that correspond with their gender identity was a violation under Title IX, the federal law that prohibits discrimination in institutions that receive federal funding"); Jeremy W. Peters et al, Trump Rescinds Rules on Bathrooms for Transgender Students, N.Y. TIMES (Feb. 22, 2017), https://www.nytimes.com/2017/02/22/us/ politics/devos-sessions-transgender-students-rights.html [https://perma.cc/8C9U-SRYJ].

262. See German Lopez, We Asked US Voters About their Views on Transgender People. Here's What they Said., Vox (May 24, 2016), https://www.vox.com/2016/5/24/11746086/transgender-bathrooms-poll-survey [https://perma.cc/6NFD-FBFP] (noting that Americans hold more unfavorable views toward transgender people than other groups). A significant number of Americans think trans people are mentally ill. See Samantha Allen, Why A Lot of Americans Don't Want To Befriend a Transgender Person, DAILY BEAST (May 22, 2017), https:// www.thedailybeast.com/why-a-lot-of-americans-dont-want-to-befriend-a-transgender-person?ref=scroll [https:// perma.cc/6TFM-VXFG] (noting that one in five Americans believe that transgender individuals have a mental illness); Julia Clark \& Chris Jackson, Ipsos, Global Attitudes Toward Transgender People (2018), https://www.ipsos.com/en-us/news-polls/global-attitudes-toward-transgender-people [https://perma.cc/9DLZQAAY] (noting that among all the western countries, people in the United States are the most likely to believe that transgender people have a mental illness $(32 \%)$ and the most likely to believe that transgender people are committing a sin (32\%)); Yael Bame, $21 \%$ of Americans Believe That Being Transgender is a Mental Illness, YouGov (May 17, 2017), https://today.yougov.com/topics/relationships/articles-reports/2017/05/17/21americans-believe-identifying-transgender-menta [https://perma.cc/2UDP-K493] (noting that 21\% of Americans think that identifying as transgender is a form of mental illness); J. Lester Feder et al., This Is How 23 Countries Feel About Transgender Rights, BuZzFEEDNEws (Dec. 29, 2016), https://www.buzzfeednews.com/article/ lesterfeder/this-is-how-23-countries-feel-about-transgender-rights [https://perma.cc/NP7A-8N9C] (noting that $32 \%$ of Americans agree that one who identifies as a transgender person has a form of mental illness).

263. Ctr. for the Study of Hate \& Extremism, Cal. State Univ., San Bernardino, Report to the Nation: Hate Crimes Rise in U.S. Cities and Counties in Time of Division \& Foreign InTerference (2018) (reporting that " $[\mathrm{t}] \mathrm{he} 2017$ increase in hate crime from 229 to 254 , was driven in part by the 23 crimes targeting the transgender community, which increased by 187 percent"); Dawn Ennis, American Medical 
is not merely fringe elements who are openly expressing hostility towards transgender individuals. Hostility toward the transgender community is also reflected in the remarks of suburban parents opposing policies that would allow transgender youth to use the bathroom that corresponds to their gender identity. ${ }^{264}$

When the President endorses policies that discriminate against transgender individuals, ${ }^{265}$ individuals who are biased against transgender individuals are assured that their anti-trans bias is normal and nothing to be ashamed about. As Professor Dean Spade notes, "When transphobia gets bolstered by signals from the federal government, low-level enforcers of gender norms feel even more license to humiliate and exclude trans people." 266

Even before Trump became President of the United States, explicit anti-trans bias was manifested by those invoking the safety of women and girls as a reason to prohibit transgender females from using women's restrooms. ${ }^{267}$ The bathroom safety argument perpetuates the stereotype of the transgender individual as a sexual predator, suggesting that an individual who was thought to be male when born but self-identifies as a girl, and wants to use the girls' restroom or locker room, is really just a man (or boy) wanting to sexually assault women (or girls). ${ }^{268}$

Association Responds To 'Epidemic' Of Violence Against Transgender Community, Forbes (June 15, 2019), https://www.forbes.com/sites/dawnstaceyennis/2019/06/15/american-medical-association-responds-to-epidemicof-violence-against-transgender-community/\#346970aa510b [https://perma.cc/U3DZ-S2SC] (noting that "[t]he American Medical Association is taking a public stand to stem what it calls 'the epidemic of violence against the transgender community, especially the amplified physical dangers faced by transgender people of color'”).

264. See G.G. ex rel. Grimm v. Gloucester Cty. Sch. Bd., 822 F.3d 709, 716 (4th Cir. 2016).

265. Not everyone agrees that the Trump Administration is hostile to the trans community. In August 2019, Robert Kabel, the chairman, and Jill Homan, the vice chairwoman, of the Log Cabin Republicans - the nation's original and largest organization representing LGBT conservatives_-published an op-ed in the Washington Post, in which they claimed President Trump defends LGBTQ rights. Robert Kabel \& Jill Homan, Trump Defends LGBTQ Rights. He Has Our Endorsement, WASH. Post, Aug. 16, 2019, at A19. This op-ed prompted several members of the Log Cabin Republicans to leave the group. Colby Itkowitz, Top Official Resigns After LGBTQ Groups's Trump Endorsement, WASH. Post, Aug. 28, 2019, at A18.

266. Dean Spade, Right-Wing Fantasies About Gender are Killing Trans People, Truthout (Oct. 22, 2018), https://truthout.org/articles/right-wing-fantasies-about-gender-are-killing-trans-people/ [https://perma.cc/ X7KH-M56V].

267. See Shayna Medley, Not in the Name of Women's Safety: Whole Woman's Health as a Model for Transgender Rights, 40 HARV. J.L. \& GENDER 441, 443 (2017) (noting that anti-trans bills "almost universally claim to serve an interest in women's health and safety" and often "come in the form of fear-mongering campaigns about sexual assault in bathrooms, suggesting that transgender people are sexual predators and that cisgender men will abuse non-discrimination laws to assault women in the bathroom"); see also Rushin \& Carroll, supra note 62, at 42 (arguing that some proposed bathroom laws, prohibiting transgender individuals from using the bathroom that corresponds with their gender identity, effectively criminalize noncriminal conduct inextricably linked to the status of being trans and thus violate the Eighth Amendment's prohibition against cruel and unusual punishment).

268. Laura Portuondo, The Overdue Case Against Sex-Segregated Bathrooms, 29 YALE J.L. \& FeminisM 465, 492 (2018) (noting that "[i]nvocations of women's safety as a justification for sex-segregated bathrooms feature prominently in briefs and complaints in the transgender litigation context"). Portuondo notes that in one lawsuit "challenging the Obama Administration's trans-inclusive Title IX guidance, . . . a group of self-described 'radical feminists' asserted that allowing transgender women into women's bathrooms would undermine the 'safety offered by restrooms' and would lead to an 'increased risk of sexual assault."' Id. (citing Complaint IIII 30, 32, Women's Liberation Front v. U.S. Dep't of Justice, No. 1:16-cv-00915 (D.N.M. Aug. 11, 2016)). 
Members of the Trump Administration have reinforced the stereotype of the transgender individual as sexual predator by invoking the risk-of-sexual-assaultin-the-bathroom argument despite the lack of evidence that bathroom use by trans individuals increases the risk of assault. ${ }^{269}$ For example, during the 2016 Trump presidential campaign, Vice President Mike Pence argued that in deciding whether to allow transgender students to use the bathroom that corresponds to their gender identity, states should protect the "safety and privacy of children," 270 terms often used by those who seek to prevent transgender students from using the restrooms consistent with their identity." ${ }^{271}$ Steve Bannon, who would soon become President Trump's Chief Strategist, ${ }^{272}$ spoke out against Target when the company announced in April 2016 its decision to allow trans individuals to use the bathroom corresponding to their gender identity. ${ }^{273}$ In May 2016, Bannon opined on his Breitbart News Daily show that Target was "trying to exclude people who are

Portuondo also notes that "North Carolina Governor McCrory asserted the 'safety of women and children' as a primary motivation for the state's Bathroom Bill in Carcaňo." Id. (citing Carcaňo v. McCrory, 203 F. Supp. 3d 615, 645 (M.D.N.C. 2016)); see also Tim Madigan, What Happened When a Room Full of Texas Parents Took on Transgender Bathrooms, WASH. PoST (May 11, 2016), https://www.washingtonpost.com/news/post-nation/ wp/2016/05/11/transgender-students-rights-the-debate-becomes-loud-and-heated-in-texas/ [https://perma.cc/ MCR5-GACQ] (noting that hundreds came to a meeting in Fort Worth, Texas to express their views on school district guidelines intended to accommodate the needs of transgender students, with many expressing their opposition to allowing transgender students to use the bathroom corresponding with their gender identity). For an examination of the history behind sex segregation in public restrooms that emphasizes the risk of sexual assault and need for privacy perspective, see W. Burlette Carter, Sexism in the 'Bathroom Debates': How Bathrooms Really Became Separated by Sex, 37 YALE L. \& POL'Y REV. 227, 227 (2018) (challenging two "widely-embraced theories about how public intimate spaces ... first became separated by sex" and arguing that these theories "offer a narrative that oppresses women" and ignores women's struggles with sexual assault and sexual harassment).

269. Rushin \& Carroll, supra note 62, at 41 ("Even if one adopts the position . . . that states may seek to regulate conduct linked to a status that produces social harm, there is no evidence that bathroom use by trans individuals actually produces such harm) (citing Bryan Tannehill, Debunking Bathroom Myths, HuFF. POST (Nov. 28, 2016), https://www.huffpost.com/entry/debunking-bathroom-myths_b_8670438).

270. Sam Williamson, Note, G.G. ex rel. Grimm v. Gloucester County School Board: Broadening Title IX's Protections for Transgender Students, 76 MD. L. REv. 1102, 1125 (2017) (citing Anugrah Kumar, Mike Pence to James Dobson: Trump Will Resolve Birth Control Mandate, Transgender Bathroom Issues, CHRISTIAN POST (Oct. 5, 2016), http://www.christianpost.com/news/mike-pence-james-dobson-trump-birth-control-mandatetransgender-bathroom-170485/ [https://perma.cc/S36G-SJFS].

271. Id.

272. Meghan Keneally, A Timeline of Trump and Bannon's Turbulent Relationship, ABC News (Jan. 5, 2018), https://abcnews.go.com/Politics/timeline-trump-bannons-turbulent-relationship/story?id=52137016 (noting that "Trump announced that Bannon had joined the campaign as the new CEO" on August 16, 2016 and that Bannon was forced to resign from his position with the White House on August 18, 2017).

273. Continuing to Stand for Inclusivity, TARGET (Apr. 19, 2016), https://corporate.target.com/article/2016/ 04/target-stands-inclusivity [https://perma.cc/UFB7-YFF8] (announcing that they "welcome transgender team members and guests to use the restroom or fitting room facility that corresponds with their gender identity"); see also Williamson, supra note 270, at 1125 (citing Human Rights CAMPaign, Donald Trump: Opposes NATIONwIDE MARRIAGE EQUALITY (2016), http://www.hrc.org/2016RepublicanFacts/donald-trump-opposesnationwide-marriage-equality [https://perma.cc/T2R9-BR98] (noting that Steve Bannon "publicly advocated against allowing transgender people to use bathrooms consistent with their gender identity by preying on fears about daughters using the same bathroom as men")). 
decent, hard-working people who don't want their four-year-old daughter to have to go into a bathroom with a guy with a beard in a dress."274 In September 2019, Ben Carson, Trump's Secretary of Housing and Urban Development (HUD), expressed concern at a meeting with HUD staff about transgender women "trying to infiltrate homeless women's shelters," referring to them as "big, hairy men" and lamenting that "society no longer seems to know the difference between men and women." 275

Just as President Trump's racist rhetoric ${ }^{276}$ has emboldened many with similar views to say racist things and to act out in racially violent ways,${ }^{277}$ his trans-hostile

274. Miranda Blue, Anti-LGBT Activists 'Testing' Target By Sending Men Into Women's Rooms, RigHT WiNG WATCH (May 2, 2016) https://www.rightwingwatch.org/post/anti-lgbt-activists-testing-target-by-sending-meninto-womens-rooms/ [https://perma.cc/4TRC-TFDJ]; Rhuaridh Marr, Trump: Steve Bannon has "Lost his Mind", MetRo WeEKLY (Jan. 3, 2018) https://www.metroweekly.com/2018/01/trump-steve-bannon-lost-mind/ [https://perma.cc/S2KE-7QBZ].

275. Tracy Jan \& Jef Stein, Carson's Remarks on Gender at Meeting Rankle Staffers, WASH. Post (Sept. 20, 2019), https://www.washingtonpost.com/business/2019/09/19/hud-secretary-ben-carson-makes-dismissivecomments-about-transgender-people-angering-agency-staff/ [https://perma.cc/VP44-2U5R] (noting also that when he was running for President, Ben Carson referred to transgender people as "abnormal"); Tracy Jan, As Democrats Call for His Resignation, HUD Secretary Ben Carson Defends His Controversial Comments About Transgender People, WASH. Post (Sept. 20, 2019), https://www.washingtonpost.com/business/2019/ 09/20/democrats-call-his-resignation-hud-secretary-ben-carson-defends-his-controversial-comments-abouttransgender-people/ [https://perma.cc/SJ9Q-WTXJ].

276. Unlike previous Presidents, Donald Trump has regularly engaged in what many have called racist rhetoric targeting immigrants and racial and ethnic minorities, from suggesting that most immigrants from Mexico are criminals and rapists, see Katie Reilly, Here Are All the Times Donald Trump Insulted Mexico, TIME (Aug. 2016), https://time.com/4473972/donald-trump-mexico-meeting-insult/ [https://perma.cc/BKF8-DCWR], and that a judge of Mexican descent could not fairly adjudicate a case involving Trump, see Z. Byron Wolf, Read this: How Trump Defended Criticism of Judge for Being 'Mexican', CNN (Apr. 20, 2017), https://www.cnn.com/ 2017/04/20/politics/donald-trump-gonzalo-curiel-jake-tapper-transcript/index.html [https://perma.cc/US777TJV], to telling four progressive Congresswomen of color to go back to where they came from, suggesting that they were foreigners from other countries when three of the Congresswomen were born in the United States and all four were American citizens. See Allan Smith, Trump Says Congresswomen of Color Should 'Go Back' and Fix the Places They 'Originally Came From', NBC News (July 14, 2019), https://www.nbcnews.com/politics/ donald-trump/trump-says-progressive-congresswomen-should-go-back-where-they-came-n1029676. In July 2019, Trump attacked then Congressman Elijah Cummings, a vocal critic of Trump, tweeting that the African American's district—which includes Baltimore-was "disgusting" and a "rat and rodent infested mess." Ledyard King, 'Don't Just Come and Criticize': Elijah Cummings Defends Baltimore in Face of Trump's insults, USA TODAY (Aug. 3, 2019), https://www.usatoday.com/story/news/politics/2019/08/03/elijahcummings-defends-baltimore-trump-attacks-during-park-event/1909733001/; P.R. Lockhart, How Trump Used a Centuries-Old Racist Trope to Attack Baltimore, Vox (July 29, 2019), https://www.vox.com/identities/2019/ 7/29/20746188/donald-trump-elijah-cummings-baltimore-rat-infested-racism [https://perma.cc/58AH-F3DJ]. Trump has embraced harsh immigration policies, aimed at stopping Mexicans and others from Central and South America from coming across the border. See Andy J. Semotiuk, Immigrants Troubled By Trump's New Immigration Policy Restrictions, ForBES (Aug. 23, 2019), https://www.forbes.com/sites/andyjsemotiuk/2019/ 08/23/immigrants-troubled-by-trumps-new-immigration-policy-restrictions/\#5b3bc0013b34 [https://perma.cc/ 364J-PA69]; Michael D. Shear et al., Trump's Policy Could Alter the Face of the American Immigrant, N.Y. TIMES (Aug. 14 2019), https://www.nytimes.com/2019/08/14/us/immigration-public-charge-welfare.html [https://perma.cc/PFT8-8SH8]. Not everyone sees Trump's rhetoric as racist. See Meredith Dost et al., Is President Trump's Rhetoric Racist? It Depends on Whom You Ask, WASH. PosT (Aug. 12, 2019), https:// beta.washingtonpost.com/politics/2019/08/12/is-president-trumps-rhetoric-racist-it-depends-whom-you-ask/ [https://perma.cc/32MK-QK5Y] (noting that Americans disagree on whether Trump's rhetoric is racist). 
policies have emboldened individuals with negative views about trans people to say trans-hostile things and to act out in trans-hostile ways.

For example, in May 2018, Jazmina Saavedra, a Republican running for Congress, posted a live Facebook video of a confrontation she had with a transgender female at a Denny's restaurant in Los Angeles. ${ }^{278}$ Saavedra told reporters that the incident "started when a waitress told her there was a man who said he was a woman using the women's restroom." 279 Saavedra went into the restroom with her cellphone and confronted the transgender woman who was inside one of the bathroom's stalls, asking (while videotaping herself), "Why you use the ladies' room?"280 The transgender woman responded by saying, "You're invading my privacy." ${ }^{281}$ Saavedra confronted the transgender woman again when she left the restroom. ${ }^{282}$ Showing her lack of understanding regarding the difference between gender identity and sexual orientation, Saavedra justified her actions as representative of not just her views but of the views of the other customers as well, telling reporters, "This is so stupid . . this [has] nothing to do about gay or nothing. This is about how myself [sic] and the other customers feel in danger by hearing a voice of a man inside." 283 She added that she did

Trump's supporters apparently like his inflammatory rhetoric. See Astead W. Herndon, With the Faithful at Trump's North Carolina Rally: 'He Speaks Like Me,' N.Y. TIMES (Sept. 11, 2019), https://www.nytimes.com/ 2019/09/10/us/politics/trump-voters-supporters-policies.html [perma.cc/382Y-ARGQ] (noting that "[i]n conversations with more than a dozen attendees before and after [Trump's September 9, 2019 North Carolina] rally, they made clear that their support for the president was not in spite of his inflammatory rhetoric, but because his chosen targets often match their own").

277. As Bobbi Strang, President of the District of Columbia's Gay and Lesbian Activists Alliance, observed "[e]verywhere people are feeling empowered to say and act according to their worst impulses." See Michael E. Miller, In 2018, They All Became the Victims of a Record Year of Hatred in D.C., WASH. PosT, Aug. 26, 2019, at Al, A12 ("Many people who track hate crimes see a connection between Trump's ugly political rhetoric aimed at immigrants and people of color and what has been unleashed in communities across the country."); see also Tessa Berenson, Donald Trump's Own Words Undermine His Case After El Paso Shooting, Time (Aug. 5, 2019), https://time.com/5644433/donald-trump-el-paso-shooting-words/ [https://perma.cc/2SLD-KY68] (noting that many Democrats blamed Trump's racist rhetoric for the El Paso shooting); Libby Nelson, "Why We Voted for Donald Trump": David Duke Explains the White Supremacist Charlottesville Protests, Vox (Aug. 12, 2017) https://www.vox.com/2017/8/12/16138358/charlottesville-protests-david-duke-kkk [https://perma.cc/NPT2W9GA] (noting that former KKK Grand Wizard David Duke proclaimed, "We are going to fulfill the promises of Donald Trump" at the neo-Nazi and alt-right rally in Charlottesville, Virginia in August 2017); Richard Parker, When Hate Came to El Paso, N.Y. TIMES (Aug. 4, 2019), https://www.nytimes.com/2019/08/04/opinion/ el-paso-shooting.html [https://perma.cc/A4JY-SL3V] (opining that "the El Paso massacre ... was the inevitable byproduct of the Trump era's anti-immigrant, and anti-Latino invective, which with its pervasive, vile racism has poisoned our nation").

278. LA Congressional Candidate Posts Video of Denny's Bathroom Confrontation, ABC7 News (May 18, 2018), https://abc7.com/politics/la-congressional-candidate-posts-video-of-dennys-bathroom-confrontation/ 3489200/ [https://perma.cc/DP2T-PAKE].

279. Id.

280. Id.

281. Id.

282. Id.

283. Id 
not regret anything she said in her video. ${ }^{284}$

It is rare for an individual to videotape themselves confronting a transgender person in the bathroom as Saavedra did. Indeed, many harassing incidents trans people experience are not even reported in the mainstream news media, but this does not mean that they are not occurring. ${ }^{285}$ I happened to find out about another such incident from a fellow female law professor colleague when I told her that I was writing this Article. In February 2018, my colleague took a transgender woman friend out for a bachelorette pub crawl two nights before her friend's wedding. When they got to a lesbian bar in New York City, the bouncer refused to let the transgender bride-to-be in. "She can't come in," the bouncer said, pointing to the bride-to-be. Astounded that this would happen at a lesbian bar, the law professor asked the bouncer, "Why not?" Looking at the bride-to-be's driver's license, which had been legally changed to show her sex as female, the bouncer responded, "It says she's female and she's not." Incredulous, the law professor asked, "What do you mean?" Oddly (or perhaps not so oddly), the bouncer replied, "Just blame Trump because I voted for him."286

284. Id.; see also Michelle Gant, Congressional Candidate Confronts Transgender Woman at Denny's for Using Women's Bathroom, Fox News (May 18, 2018), https://www.foxnews.com/food-drink/congressionalcandidate-confronts-transgender-woman-at-dennys-for-using-womens-bathroom [https://perma.cc/C3LP-R273]; Diana Stancy Correll, GOP House Candidate Live Streams Herself Challenging Transgender Woman for Using Women's Restroom, WASH. EXAMINER (May 17, 2018), https://www.washingtonexaminer.com/news/gop-housecandidate-live-streams-herself-challenging-transgender-woman-for-using-womens-restroom [https://perma.cc/ JNF3-W7EY]. Fortunately, Saavedra did not succeed in her attempt to be elected to the U.S. Congress. See California Election Results: $44^{\text {th }}$ House District, N.Y. TIMES (June 11, 2018), https://www.nytimes.com/ elections/results/california-house-district-44-primary-election [https://perma.cc/4FKF-B83A]. Nanette Barragan, a Democrat, won that election with $65.9 \%$ of the votes. Id. Saavedra captured $10.1 \%$ of the votes. Id.

285. As Kendra Johnson, the Executive Director of NC Equality, noted after two women mocked and groped a transgender female who was trying to use the women's restroom, "Incidents like this are really common, but unfortunately, many transgender and non-gender-conforming folks don't have the resources or the ability to actually pursue any sort of support through law enforcement." Robert Richardson, After Incident at Raleigh Bar, LGBTQ Advocates Say Assaults Too Common, CBS17 (Jan. 9, 2019), https://www.cbs17.com/news/local-news/ wake-county-news/after-incident-at-raleigh-bar-lgbtq-advocates-say-assaults-too-common/1694626461 [https:// perma.cc/86P9-JPVA]

286. Conversation with a colleague at 2019 SEALS Annual Meeting, Boca Raton, Florida (July 29, 2019). That this incident took place at a lesbian bar is surprising but reflects a sad reality. Not all within the LGBTQ community welcome transgender individuals into that community. Some radical feminists believe that "transgender activism ... harms women, and lesbians in particular" by contributing to "lesbian erasure"-the notion that "lesbians are systematically "erased' and ignored within male-dominated LGBTQ activism and mainstream media[.]”' Julie Compton, 'Pro-lesbian' or 'Trans-exclusionary'? Old Animosities Boil into Public View, NBC NEws (Jan. 14, 2019), https://www.nbcnews.com/feature/nbc-out/pro-lesbian-or-trans-exclusionaryold-animosities-boil-public-view-n958456 [https://perma.cc/M5K8-TYT6]; see also Phaylen Fairchild, A Letter to the Lesbians Who Hate Me, MEDIUM (July 17, 2019), https://medium.com/@Phaylen/a-letter-to-the-lesbianswho-hate-me-32dcafc0893 [https://perma.cc/6HJK-7JPP]. Some radical feminists reject the existence of transgender identity and believe "advancements in transgender rights will come at the expense of women's rights and threaten the safety and sanctity of women-only spaces." Samantha Schmidt, Conservatives Find Unlikely Ally in Fighting Transgender Rights: Radical Feminists, WASH. POST (Feb. 7, 2020), https://www.washingtonpost.com/ dc-md-va/2020/02/07/radical-feminists-conservatives-transgender-rights/ [https://perma.cc/W35H-72ZW]. 
Some individuals who are explicitly biased against trans people have felt emboldened to go beyond mere words, expressing their hostility in actions. For example, on December 9, 2018, two women in their thirties "taunted, groped, and exposed themselves" to a twenty-nine-year-old transgender woman in the bathroom of a North Carolina bar. ${ }^{287}$ The two women continued to harass the transgender woman at the bar, despite the bartender's repeated requests to stop. ${ }^{288}$ One of the women asked the transgender woman whether she had a penis. ${ }^{289}$

A skeptic might say these incidents are isolated and just anecdotal evidence of anti-trans bias, but when considered along with the statistics discussed in Part I, it is hard to see these as anything other than a larger pattern of harassment, discrimination, and violence against the trans community. If a juror thinks that trans people are abnormal, that juror is not likely to be persuaded by prosecutorial appeals to see the trans victim as a vulnerable person who had good reasons to be reluctant to disclose that she was born with male genitalia. All the education in the world will not encourage an individual who is explicitly biased against transgender individuals to see the victim in a trans panic case as an ordinary human being who did nothing to provoke the defendant other than being a transgender person. ${ }^{290}$

\section{B. Possible Objections to Legislatively Banning the Trans Panic Defense}

Before examining the legislative bans that been enacted thus far, I will address potential objections to legislatively banning the trans panic defense. Many of these potential objections are arguments I raised in my previous scholarship.

287. Michael Brice-Saddler, Two Women Charged with Sexually Assaulting a Transgender Woman in a North Carolina Bar Bathroom, WASH. Post (Jan. 9, 2019), https://www.washingtonpost.com/nation/2019/01/09/twonorth-carolinians-charged-with-sexually-assaulting-transgender-woman-bar-bathroom [https://perma.cc/LM98XPK8].

288. Id.

289. Id. The two women were arrested and charged with sexual battery and second-degree kidnapping. Id. This incident occurred in the wake of highly controversial legislative action. In 2016, the North Carolina legislature passed legislation requiring people to use the public restroom that corresponds with the sex listed on their birth certificate rather than their gender identity. Id. North Carolina's bathroom bill adversely affected the transgender community because North Carolina only permits individuals who have undergone sex-reassignment surgery to change the sex listed on their birth certificate. N.C. GEN. STAT. § 130A-118(b)(4) (2019). North Carolina's controversial bathroom bill ("H.B. 2") led many to boycott North Carolina. See 'Bathroom Bill' to Cost North Carolina \$3.76 Billion, CNBC (Mar. 27, 2017), https://www.cnbc.com/2017/03/27/bathroom-bill-tocost-north-carolina-376-billion.html [https://perma.cc/3MWB-9WEG]. After losing a lot of business because of H.B. 2, the North Carolina legislature repealed H.B. 2 in 2017 and replaced it with legislation preventing local governments from passing ordinances to protect LGBT individuals. See Brice-Saddler, supra note 287; Jason Hanna et al., North Carolina Repeals 'Bathroom Bill', CNN (Mar. 30, 2017), https://www.cnn.com/2017/03/30/ politics/north-carolina-hb2-agreement/index.html [https://perma.cc/72BM-FZ4Y].

290. Making bias salient didn't work in the Brandon McInerney case. See Mallory M. Craig-Harim, Subverting the Perverted Practice of Provocation: Eliminating Modern Day Uses of LGBT Panic Defenses, 27 TUL. J.L. \& SEXUALiTY 33, 34 n.2, 45 (2018) (coining the term "LGBT panic defenses" to encompass both gay panic and trans panic and pointing out that making LGBT biases salient did not help in the Brandon McInerney case); see also supra text accompanying notes 130-43. 


\section{Objection One: Even with a Legislative Ban, the Defendant Can Still Take the Stand and Get the Trans Panic Argument Before the Jury}

One potential objection to a legislative ban on the trans panic defense is that the defendant in a criminal case has a constitutional right to testify in his defense ${ }^{291}$ and thus get the trans panic argument before the jury. Even in a jurisdiction where the trans panic defense strategy has been legislatively banned, a defendant claiming trans panic can take the stand and tell the jury that he was so upset when he found out that the victim was a transgender individual that he lost his selfcontrol. ${ }^{292}$ Even though the defendant would be barred from arguing that it was objectively reasonable for him to be provoked by this discovery, the defendant would still be able to tell the jury that he was in fact provoked into a heat of passion by the discovery that the victim was a transgender woman. Male jurors who would themselves be upset if they found out that they had been sexually intimate with or romantically attracted to a transgender woman, and female jurors who think transgender people are deviant and abnormal might sympathize with the defendant and feel he should not be punished for murder. As I have previously noted, "[j]urors who are not already sensitive to the violence and discrimination leveled against the transgender community may be reluctant to condemn the defendant who claims he was provoked into a heat of passion by the discovery that the individual with whom he was intimate was biologically male." 293

It is true that even with a legislative ban on the trans panic defense, a defendant could present the idea that he acted out of "trans panic" before the jury. ${ }^{294}$ However, while such testimony would help the defendant satisfy the first element of a provocation defense - that the defendant was actually provoked into a heat of passion - it would not satisfy the second element - that there was legally adequate provocation in a jurisdiction with a legislative ban on the trans panic defense. ${ }^{295}$ To receive the provocation mitigation to voluntary manslaughter, a defendant would also have to convince the jury that the reasonable person in his shoes would have been provoked into a heat of passion. ${ }^{296}$ If a legislative ban were in place stating

291. Rock v. Arkansas, 483 U.S. 44, 49 (1987).

292. Lee \& Kwan, supra note 24, at 122 ("Fourth, the defendant has a constitutional right to testify, so even if the legislature were to enact a ban on trans panic defense arguments, the defendant would still have a constitutional right to tell his side of the story, and his story could include mention that he got tremendously upset upon discovering that his intimate partner was biologically male.").

293. Id.

294. While criminal defendants have a right to testify in their own defense, many do not exercise this right because if they take the stand and testify, the government has a right to admit evidence of prior convictions that otherwise would be inadmissible. See FED. R. EVID. 609.

295. See supra text accompanying notes 96-98.

296. See supra text accompanying note 98 . Which party bears the ultimate burden of proving (or disproving) the elements of the provocation defense depends on how legislators in the State in question drafted the provocation statute. Compare Mullaney v. Wilbur, 421 U.S. 684, 691-92, 703-04 (1975) (finding that Maine law violated Due Process in placing the burden of establishing the provocation defense by a preponderance of the evidence on the defendant), with Patterson v. New York, 432 U.S. 197, 206-07 (1997) (holding that New York 
that an alleged provocation is not reasonable if it resulted from the discovery of the victim's gender identity, the jury would not be able to lawfully return a voluntary manslaughter verdict. The only way a jury could return a voluntary manslaughter verdict for a defendant in such a jurisdiction would be by engaging in jury nullification. ${ }^{297}$

A legislative ban prohibiting the trans panic defense would remove the jury's ability to lawfully return a voluntary manslaughter conviction. The jury would have to engage in jury nullification if it wanted to give the defendant claiming trans panic a break. Since existing research suggests most juries try to follow the law and do not engage in jury nullification, the likelihood that a jury in a trans panic case would flout the law and acquit defendants who claim trans panic is small. ${ }^{298}$

\section{Objection Two: A Legislative Ban Would Violate the Defendant's Due Process Right to Present a Defense}

Another potential objection to a legislative ban on the trans panic defense is that such a ban would infringe upon the defendant's due process right to present a

law, which placed the burden of proving extreme emotional disturbance on the defendant, comported with Due Process because such a showing would not "serve to negative any facts of the crime which the State is to prove in order to convict of murder"). To suggest, as the U.S. Supreme Court has done, that the provocation defense is a case-in-chief defense under which the provoked defendant is asserting that he lacked the mens rea for murder, and therefore the prosecution should bear the burden of disproving the elements of provocation, is not persuasive. In many provocation cases, the provoked killer fully intended to kill the victim and is simply arguing that his actions are understandable and should be partially excused given the circumstances, not that he lacked the mens rea required for murder.

297. Jury nullification refers to the jury's power to acquit a defendant even in the face of overwhelming evidence of guilt. See Paul Butler, Racially Based Jury Nullification: Black Power in the Criminal Justice System, 105 YALE L.J. 677, 700 (1995) (explaining the concept of jury nullification). There is little recent research on how often juries engage in jury nullification. This is probably because as a general matter, juries cannot be forced to talk about or explain their verdicts. See FED. R. EVID. 606(b) (subject to few exceptions, "[d]uring an inquiry into the validity of a verdict or indictment, a juror may not testify about any statement made or incident that occurred during the jury's deliberations; the effect of anything on that juror's or another juror's vote; or any juror's mental processes concerning the verdict or indictment"); Pena-Rodriguez v. Colorado, $137 \mathrm{~S}$. Ct. 855, 864-67 (2017) (discussing Rule 606(b) and explaining that recognized exceptions to this "noimpeachment rule" are narrow). The available research, however, suggests that jury nullification probably occurs in only $4 \%$ of the few criminal cases that go to trial. See Jack Boeglin \& Zachary Shapiro, A Theory of Differential Punishment, 70 VAND. L. REV. 1499, 1511 (2017) (noting that "while the frequency with which jury nullification occurs is notoriously difficult to calculate, the best estimates are that nullification occurs in only about four percent of criminal cases, and less than ten percent of criminal cases come in front of a jury in the first place" (citing Aaron McKnight, Jury Nullification as a Tool to Balance the Demands of Law and Justice, 2013 B.Y.U. L. REV. 1103, 1109 (2014))).

298. Since the very first ban on gay and trans panic defenses was enacted in 2014 and several of the existing bans were enacted the year this Article was being written, it is unclear whether juries in these jurisdictions are engaging in jury nullification in gay panic and trans panic cases. Most likely, the legislative bans that have been enacted thus far are encouraging defendants who might otherwise assert a gay or trans panic defense to plead guilty since their chances of success at trial are substantially diminished in a jurisdiction with a legislative ban in place. 
defense. ${ }^{299}$ The U.S. Supreme Court has addressed whether limiting a defendant's right to present a defense in other contexts violates due process, and its answer is a resounding no. ${ }^{300}$

For example, in Montana v. Egelhoff, ${ }^{301}$ the Court considered a due process challenge to a Montana statute that barred the consideration of voluntary intoxication by jurors "in determining the existence of a mental state that is an element of the offense." ${ }^{302}$ The defendant argued that the Montana statute violated his due process right to present evidence in his defense. ${ }^{303}$

A plurality of the Court, in an opinion written by Justice Antonin Scalia, rejected the Montana Supreme Court's conclusion that the statute violated due process. ${ }^{304}$ Justice Scalia started by noting that the Montana Supreme Court based its decision on "the proposition that the Due Process Clause guarantees a defendant the right to present and have considered by the jury 'all relevant evidence to rebut the State's evidence on all elements of the offense charge." ${ }^{305}$ This proposition, Justice Scalia explained, was not correct because a defendant's right to present evidence is not absolute. ${ }^{306}$

The plurality acknowledged that the Due Process Clause does place some limits on states attempting to restrict a defendant's right to present a defense, ${ }^{307}$ but

299. In Chambers v. Mississippi, the Supreme Court stated that " $\mathrm{t}]$ he right of an accused in a criminal trial to due process is, in essence, the right to a fair opportunity to defend against the State's accusations." 410 U.S. 284, 294 (1973).

300. See Montana v. Egelhoff, 518 U.S. 37, 56 (1996); Clark v. Arizona, 548 U.S. 735, 779 (2006). I find these cases troubling because I think a defendant should have a nearly absolute right to present a defense, particularly if the defendant is asserting a case-in-chief defense, i.e. one in which the defendant alleges that the government has failed to prove an element of the charged offense. See Lee \& Kwan, supra note 24, at 84 (arguing that banning a case-in-chief defense is "problematic since the prosecution bears the burden of proving every essential element of the charged offense"). Case-in-chief defenses are commonly called failure-of-proof defenses. See 2 Wayne LaFAve, Substantive Criminal LAW. § 9.1(a)(1) (3d ed. 2018) (defining a "failure of proof" defense as "one in which the defendant has introduced evidence at his criminal trial showing that some essential element of the crime charged has not been proved beyond a reasonable doubt"). A defendant asserting a gay or trans panic defense tied to the doctrine of provocation, however, is not asserting a case-in-chief defense. The defendant is not alleging that he lacked the mens rea or any other element of the charged offense. Provocation is usually considered an affirmative defense, as opposed to a case-in-chief defense. See Reid G. Fontaine, Adequate (Non)Provocation and Heat of Passion as Excuse Not Justification, 43 U. MicH. J.L. REFORM 27, 29 (2009) (noting that "[a] majority of United States jurisdictions recognize . . heat of passion as an affirmative, partial defense to murder"); 21 AM. JURIS. 2D CRIM. L. § 177 (2019) (describing an affirmative defense as "one that admits the doing of the act charged, but seeks to justify, excuse, or mitigate it," and distinguishing "simple defenses," which attempt to negate an element of the offense).

301. 518 U.S. 37 (1996).

302. Mont. Code AnN. § 45-2-203 (2019).

303. Egelhoff, 518 U.S. at 39-40 ("We consider in this case whether the Due Process Clause is violated by Montana Code Annotated $\S 45-2-203$, which provides, in relevant part, that voluntary intoxication 'may not be taken into consideration in determining the existence of a mental state which is an element of [a criminal] offense."').

304. Id. at 56 .

305. Id. at 41-42 (citation omitted).

306. Id. at 42 .

307. Id. at $42-43$. 
observed that "the defendant asserting such a limit must sustain the usual heavy burden that a due process claim entails[.]"308 Justice Scalia explained:

Preventing and dealing with crime is much more the business of the States than it is of the Federal Government, and ... we should not lightly construe the Constitution so as to intrude upon the administration of justice by the individual States.... [I]t is normally within the power of the State to regulate procedures under which its laws are carried out, ... and its decision in this regard is not subject to proscription under the Due Process Clause unless it offends some principle of justice so rooted in the traditions and conscience of our people as to be ranked as fundamental. ${ }^{309}$

In other words, a defendant alleging a due process violation must show that the state has offended a "fundamental principle of justice." 310 The plurality found that the defendant failed to show that the rule prohibiting defendants from introducing evidence of voluntary intoxication offended a principle of justice "so rooted in the tradition and conscience of our people as to be ranked as fundamental." 311

Important to the plurality's conclusion was this country's long common law tradition of disallowing defendants from offering evidence of voluntary intoxication in their defense. ${ }^{312}$ Even though courts in the nineteenth century "carve[d] out an exception to the common law's traditional across-the-board condemnation of the drunken offender, allowing a jury to consider a defendant's intoxication when assessing whether he possessed the mental state needed to commit the crime charged, where the crime was one requiring a "specific intent," 313 the plurality noted that "one-fifth of the States either never adopted [this] 'new common-law' rule ... or [later] abandoned it." 314 The fact that many states retained or reinstated the original common law rule prohibiting defendants from offering evidence of voluntary intoxication in their defense convinced the plurality that the more recent common law rule that allowed defendants to present such evidence to negate the mens rea was not a fundamental principle of justice. ${ }^{315}$

The plurality also rejected the Montana Supreme Court's interpretation of a statement in Chambers v. Misssissippi that "the right of an accused in a criminal trial to due process is, in essence, the right to a fair opportunity to defend against

308. Id. at 43 .

309. Id. (quoting Patterson v. New York, 432 U.S. 197, 201-02 (1977)) (internal quotations and citations omitted).

310. Id.

311. Id. at 47-48 ("It is not the State which bears the burden of demonstrating that its rule is 'deeply rooted,' but rather respondent who must show that the principle of procedure violated by the rule (and allegedly required by due process) is 'so rooted in the traditions and conscience of our people as to be ranked as fundamental' . . . [t]hat showing has not been made.").

312. Id. at 44-45 (noting extensive evidence of a lengthy common law tradition of rejecting intoxication as a defense).

313. Id. at 46 .

314. Id. at 48 .

315. Id. at 49 . 
the State's accusations." 316 The plurality confined the Chambers decision to the facts and circumstances of that case and found that it did not establish a new principle of due process. ${ }^{317}$

Ten years later, in 2006, the U.S. Supreme Court rejected another defendant's argument that a rule precluding him from offering evidence of mental illness to negate the mens rea of the charged offense violated his due process right to present evidence in his defense. In Clark v. Arizona, a defendant charged with first-degree murder for shooting and killing a police officer conducting a traffic stop challenged the constitutionality of an amendment to Arizona's insanity rule, disallowing defense evidence of mental illness to negate the mens rea. ${ }^{318}$ Echoing its reasoning in Egelhoff, the Court rejected the defendant's due process challenge, holding "there is no violation of due process under Chambers and its progeny, and no cause to claim that channeling evidence on mental disease and capacity offends any 'principle of justice so rooted in the traditions and conscience of our people as to be ranked as fundamental." 319

If a defendant charged with murdering a transgender woman were to challenge the constitutionality of a legislative ban on the trans panic defense, he would bear the burden of showing that the right to present evidence supporting a trans panic defense "was so deeply rooted at the time of the Fourteenth Amendment (or perhaps has become so deeply rooted since) as to be a fundamental principle which that Amendment enshrined." ${ }^{320}$ It is unlikely that a defendant would be able to meet that burden. As Jordan Blair Woods notes, the trans panic defense, a relatively new concept, is much less deeply rooted in this nation's traditions and conscience than the voluntary intoxication defense, which dates back to the $1800 \mathrm{~s} .{ }^{321}$

316. 410 U.S. 284, 294 (1973).

317. Egelhoff, 518 U.S. at 51-52. To support this interpretation, the plurality quoted the following language from Chambers v. Mississippi:

In reaching this judgment, we establish no new principles of constitutional law. Nor does our holding signal any diminution in the respect traditionally accorded to the States in the establishment and implementation of their own criminal trial rules and procedures. Rather, we hold quite simply that under the facts and circumstances of this case the rulings of the trial court deprived Chambers of a fair trial.

Id. at 52 (quoting Chambers, 410 U.S. at 302-03) (emphasis added).

318. 548 U.S. 735, 743-46 (2006).

319. Id. at 779 (citation omitted). On March 23, 2020, the Supreme Court held that the Due Process Clause does not require states to provide a specific test for insanity. See Kahler v. Kansas, 589 U.S.__ (2020) (rejecting due process challenge to Kansas rule prohibiting criminal defendants from asserting insanity defense).

320. Egelhoff, 518 U.S. at 48 ("The burden remains upon respondent to show that the "new common-law' rule - that intoxication may be considered on the question of intent — was so deeply rooted at the time of the Fourteenth Amendment (or perhaps has become so deeply rooted since) as to be a fundamental principle which that Amendment enshrined.").

321. See Woods et al., Model Legislation for Eliminating the Gay and Trans Panic Defenses, supra note 90, at 1, 19-20 (explaining why the gay and trans panic defenses are not fundamental principles of justice protected by the Due Process Clause). 
Therefore, it is unlikely that the Supreme Court would find that a legislative ban on the trans panic defense violates a defendant's due process rights.

\section{Objection Three: A Legislative Ban is an Improper Attempt to Legislate} Social Attitudes

A third potential objection is that a legislative ban on the trans panic defense strategy is an attempt to legislate social attitudes. Underlying this argument is the assumption that the law should follow rather than lead social attitudes. ${ }^{322}$

While the law often follows social attitudes, ${ }^{323}$ it is not uncommon for the law to lead rather than follow. For example, in the 1970s and 1980s, feminists successfully pushed for reform of rape laws. ${ }^{324}$ Even though social attitudes at that time about the way women should behave in matters involving sex differed significantly from social attitudes today, ${ }^{325}$ many legislatures eliminated the resistance requirement, which required proof that the victim resisted the sexual assault to her utmost. $^{326}$ Some legislatures also eliminated the corroboration requirement, which required corroborating evidence such as torn clothing, bruises, and scratches. ${ }^{327}$ The law of rape changed well before social attitudes changed and these changes had a profound influence on social attitudes about appropriate sexual behavior. ${ }^{328}$ Indeed, changes in the law of rape over forty years ago probably helped pave the way to today's \#MeToo movement. ${ }^{329}$

322. Cynthia Kwei Yung Lee, Race and Self Defense: Toward a Normative Conception of Reasonableness, 81 MinN. L. REv. 367, 381-83, 90 (1996) (discussing debate over whether the criminal law should adhere to a noninstrumentalist approach that focuses on the defendant's culpability or an instrumentalist approach that utilizes the criminal law to achieve broader social ends).

323. For example, some have argued that the U.S. Supreme Court's rulings in the recent marriage equality cases were the result of changes in social attitudes about heterosexuality and homosexuality. See Marco Morini, Same-Sex Marriage and Other Moral Taboos: Cultural Acceptances, Change in American Public Opinion and the Evidence from the Opinion Polls, 11 EuR. J. AM. STud. 1, 10 (2017) (arguing that Obergefell "was the product of the decades of activism that made the idea of gay marriage seem plausible and right").

324. See Aya Gruber, Rape, Feminism, and the War on Crime, 84 WASH. L. Rev. 581, 591-92 (2009) (describing the work of second-wave feminists in the 1970s and 80s to "reform rape law and educate the public about sexual assault stereotypes"); Stephen J. Schulhofer, Reforming the Law of Rape, 35 LAW \& INEQ. 335, 337 (2017) (noting that in the 1970s "[s]trong feminist organizations and rape-survivor advocacy groups joined with the general tough-on-crime movement" to push for reform of rape law).

325. For an excellent examination of social attitudes and expectations regarding sexual activity between men and women at that time, see Jeannie Suk, "The Look in His Eyes": The Story of Rusk and Rape Reform, in CRIMINAL LAW StORIES 171-211 (Foundation Press 2013); see also Gruber, supra note 324, at 630-34 (describing how gender norms have shifted under third-wave feminism).

326. See Gruber, supra note 324, at 593; Martha Chamallas, Consent, Equality, and the Legal Control of Sexual Conduct, 61 S. CAL. L. REv. 777, 799 (1988) (explaining that the "requirement that the victim prove actual physical resistance in order to negate consent has been modified or rejected in most jurisdictions").

327. See Gruber, supra note 324, at 593; Chamallas, supra note 326, at 799 n.101 (explaining that eliminating the requirement that the victim's testimony be corroborated was another significant feminist reform).

328. Chamallas, supra note 326, at 799 (noting that feminist reform of rape laws "generated a deeper understanding" around issues such as consent).

329. See Alison Gash \& Ryan Harding, \#MeToo? Legal Discourse and Everyday Responses to Sexual Violence, 7 LAws 1 (2018) (arguing that changes in rape law brought rape out of the private realm); see also 
A related objection is that a legislative ban on the trans panic defense strategy is an attempt to use the criminal law to legislate morality. Such attempts are problematic, especially in light of the constantly shifting and culturally contingent nature of morality. ${ }^{330}$ While I agree with the sentiment underlying this objection-that the criminal law should not be used to legislate morality - a legislative ban on the trans panic defense is not an attempt to legislate morality. Such a ban is not trying to tell the defendant what he should or should not be doing in his private life. Rather, it is telling the jury that as a matter of law, it is not objectively reasonable to be provoked into a heat of passion by the discovery that another person is a transgender individual.

Rather than an attempt to legislate morality, a ban on the trans panic defense is better understood as an attempt by the legislature to use the power of the law to express condemnation for certain behaviors. This is an accepted and traditional function of the criminal law. ${ }^{331}$ When a legislature chooses to ban the trans panic defense, it is simply making a normative judgment about what constitutes legally adequate provocation, as other legislatures have done before. ${ }^{332}$

A legislative ban would send a clear message to the jury that in the legislature's eyes, it is not reasonable to get so upset that one uses physical violence against a transgender woman upon discovering that her biological sex does not match her gender identity. A legislative ban would also ensure that jurors reject trans panic arguments far more effectively than a prosecutor's appeals to the jury's sense of fairness.

\section{Objection Four: If a Legislature Bans Trans Panic, It May Ban Other Equally Reprehensible Uses of the Provocation Defense}

A fourth possible objection might be called the slippery slope objection. The concern here is that if a legislature bans the trans panic defense, then it may ban

\footnotetext{
Amanda Chatel, Should We Forgive Men Who Are Accused Of Sexual Assault If They Apologize, YouRTANGO (Jan. 26, 2018), https://www.yourtango.com/2018310185/should-we-forgive-men-who-are-accused-sexualassault-if-they-apologize [https://perma.cc/2WAS-52FM] (suggesting that society should not forgive men who have engaged in sexual assault even if they apologize); Debra Soh, Do the Men of \#MeToo Deserve to be Forgiven, THE GLOBE \& MAIL (Sept. 6, 2018), https://www.theglobeandmail.com/opinion/article-do-the-menof-metoo-deserve-to-be-forgiven/ [https://perma.cc/XLG8-36G2] (noting that while most people say men guilty of a \#MeToo moment do not deserve forgiveness or a second chance, there is a double standard at work under which celebrities tend to be forgiven and are given a second chance).

330. Indeed, I raised this concern in my prior scholarship. See Lee \& Kwan, supra note 24, at 121 ("Using the criminal law to dictate morality is deeply problematic given the constantly shifting and culturally contingent nature of morality.").

331. See Henry M. Hart Jr., The Aims of the Criminal Law, 23 LAw \& CONTEMP. Probs. 401, 404-05 (1958) (explaining that "judgment of community condemnation . . a accompanies and justifies" imposition of criminal sanctions). See generally Cass R. Sunstein, On the Expressive Function of Law, 144 U. PA. L. REV. 2021, 2044 (1996) (noting that "criminal law is a prime arena for the expressive function of law").

332. See infra text accompanying notes 335-36 (discussing Maryland's legislative ban on defendants arguing that the discovering of a spouse having sexual intercourse with another person constitutes legally adequate provocation and Minnesota's legislative ban on defendants arguing that hearing a crying baby constitutes legally adequate provocation).
} 
other reprehensible arguments linked to the provocation defense. ${ }^{333}$ For example, a legislature that bans the trans panic defense might feel as a matter of principle that it must also pass legislation barring male defendants from arguing that they were reasonably provoked into a heat of passion by the discovery of their spouse having sexual intercourse with another person. Arguably, just as the defendant asserting a trans panic defense seeks to reinforce negative stereotypes about trans individuals, a defendant asserting a provocation defense under these circumstances is trying to reinforce stereotypes about the proper role of women.

My response to this argument is that even before legislatures started banning the gay and trans panic defenses, some legislatures had already categorically banned other uses of the provocation defense. For example, Maryland amended its criminal code in 1997 to bar defendants from arguing that the discovery of their spouse engaged in sexual intercourse with another constituted legally adequate provocation. ${ }^{334}$ Similarly, Minnesota amended its criminal code in 1988 to bar defendants from arguing that a crying baby constitutes legally adequate provocation. ${ }^{335}$

Indeed, we have a long history in the United States of cabining the types of arguments that defendants claiming provocation can make. As explained above, at early common law, courts recognized only five categories of legally adequate provocation. ${ }^{336}$ A defendant who did not fit within one of these five categories could not assert a provocation defense. ${ }^{337}$ Even after states abandoned the early common law approach to provocation, most retained the mere words rule, which

333. In my prior scholarship, I expressed the concern that "if a legislature can categorically ban defendants from making trans panic arguments because it believes such arguments are morally reprehensible, it could categorically ban other defense arguments on moral grounds as well.” Lee \& Kwan, supra note 24, at 121.

334. See H.R. 754, 1997 Reg. Sess. (Md. 1997) (amending the Maryland criminal code to add a section establishing that spousal adultery does not constitute provocation); Kimberly Wilmot-Weidman, After a 3-Year Fight, Murder is Finally Murder in Maryland, CHI. TRIB. (Nov. 23, 1997), https://www.chicagotribune.com/ news/ct-xpm-1997-11-23-9711230114-story.html [https://perma.cc/7Z4L-PM9F] (reporting that Maryland passed a revised law in May 1997 to remove spousal adultery as a mitigating factor to lessen a murder charge to a manslaughter charge); see also MD. CODE ANN. CRIM. LAW § 2-207(b) (2019) (providing that "[t]he discovery of one's spouse engaged in sexual intercourse with another does not constitute legally adequate provocation for the purpose of mitigating a killing from the crime of murder to voluntary manslaughter even though the killing was provoked by that discovery").

335. See 1988 Minn. Laws 670-71, ch. 604, H.F. no. 10 (amending the Minnesota criminal code to "provide[] that the crying of a child does not constitute provocation"); see also MinN. STAT. ANN. § 609.20(1) (2019) (providing that " $[\mathrm{w}]$ hoever . . . intentionally causes the death of another person in the heat of passion provoked by such words or acts of another as would provoke a person of ordinary self-control under like circumstances" is guilty of manslaughter in the first-degree "provided that the crying of a child does not constitute provocation").

336. See supra notes 93-94 and accompanying text (noting that at early common law, one could only receive the mitigation from murder to voluntary manslaughter if one fell within one of the following categories: "(1) an aggravated assault or battery, (2) the observation of a serious crime against a close relative, (3) an illegal arrest, (4) mutual combat, or (5) catching one's wife in the act of adultery.").

337. See 2 Wharton's Criminal LaW $\S 157$ (15th ed. 2019) ("In order to reduce a homicide from murder to voluntary manslaughter, there must be provocation, and such provocation must be recognized by the law as adequate."); Joshua Dressler, Rethinking Heat of Passion: A Defense in Search of a Rationale, 73 J. CRIM. L. \& CRIMINOLOGY 421, 428, 430 (1982) (giving examples of what would and would not constitute legally adequate provocation). 
prevents defendants from arguing that mere words provoked them into a heat of passion. ${ }^{338}$ In most jurisdictions today, mere words do not constitute legally adequate provocation. ${ }^{339}$

Legislative limitations on the provocation defense did not start with the recent legislative bans on gay and trans panic defenses. The history of the provocation defense reveals that the doctrine has always been a site for categorical inclusion and exclusion.

5. Objection Five: A Legislative Ban on the Trans Panic Defense Would Force the Jury to Make an All-or-Nothing Choice and Lead to More Acquittals or Hung Juries

A fifth possible objection to legislatively banning the trans panic defense is that taking away the voluntary manslaughter option would force the jury to make an all-or-nothing choice. ${ }^{340}$ If members of the jury are biased against trans people and therefore inclined to sympathize with the defendant claiming trans panic, they might choose to acquit the defendant rather than convict him of murder. ${ }^{341}$

While it is true that jurors who sympathize with the defendant might want to find him not guilty of murder, the jury would have no legal basis to acquit the defendant if the legislature has banned the trans panic defense. The jury would have to ignore the law and engage in jury nullification if it wanted to find the defendant not guilty of murder. The available research, however, suggests that juries nullify in only about four percent of all criminal cases, suggesting that most jurors take their duty to follow the law seriously and would not acquit if the law precluded such a verdict. ${ }^{342}$

A related concern is that a legislative ban on the trans panic defense might lead to more hung juries if jurors cannot agree on whether to convict the defendant of murder. ${ }^{343}$ In jurisdictions without a ban, juries can at least compromise and return

338. 40 AM. JURIS. 2D HOMICIDE $§ 51$ (2019) ("Mere words . ., no matter how insulting or abusive, will not provide such provocation so as to reduce a homicide from murder to manslaughter."); BuchhandlerRaphael, Fear-Based Provocation, supra note 104, at 1730-31 ("Most jurisdictions, however, exclude the [provocation] defense in cases involving words alone, without the deceased's additional provocative action, no matter how offensive or insulting these words might have been to the specific defendant.").

339. See Dolores A. Donovan \& Stephanie M. Wildman, Is the Reasonable Man Obsolete: A Critical Perspective on Self-Defense and Provocation, 14 Loy. L. A. L. REv. 435, 447 (1981) (explaining that "[a]uthorities agree that mere angry words" do not constitute legally adequate provocation). $C f$. People v. Berry, 556 P.2d 777, 782 (Cal. 1976) (finding that the trial court erred in refusing to give the jury an instruction on heat of passion provocation even though the defendant was largely provoked by his wife's verbal admission that she had engaged in sexual relations with another man).

340. Lee \& Kwan, supra note 24, at 121 ("[A] legislative ban on trans panic arguments would force the jury to make an all-or-nothing choice.").

341. Id. (noting that "[i]n a jurisdiction where jurors are likely to sympathize with the defendant claiming gay or trans panic, a ban could result in more victories for defendants claiming trans panic, since jurors who believe murder is too harsh would not be permitted to find the defendant guilty of the lesser offense of manslaughter").

342. Id. at 120 (discussing jury nullification).

343. Id. at 122 (noting that "[a]n all-or-nothing choice may also result in more hung juries since there is less room for compromise when the only choices are a murder conviction or a complete walk for the defendant"). 
a verdict of guilty on voluntary manslaughter, but in a jurisdiction where the only option is a murder conviction or an acquittal, juries are less likely to come to agreement. Jurors who sympathize with the defendant might be unwilling to convict the defendant of murder and jurors who think the defendant was not reasonably provoked likely might be unwilling to acquit the defendant.

As for the possibility of more hung juries, juries in trans panic cases might fail to reach agreement and hang even without a legislative ban. Even though there was no legislative ban on the trans panic defense in California at the time, the first jury in the Gwen Araujo case discussed above hung because some jurors felt the defendants should be convicted of murder while others sympathized with the defendants and felt voluntary manslaughter was the more appropriate charge. ${ }^{344}$ Similarly, the jury in the Larry King case hung even though there was no legislative ban in place at the time because some jurors felt a guilty verdict on murder was appropriate while others felt murder was too harsh and that voluntary manslaughter was more appropriate. ${ }^{345}$

6. Objection Six: A Legislative Ban Would Drive the Trans Panic Defense Underground, Enabling It to Be More Effective

Another possible objection to a legislative ban is that it would push the conversation about trans panic underground and allow jurors implicitly biased against trans individuals to simply act on their biases. This is a legitimate concern but is not ultimately persuasive because I am not arguing in favor of a legislative ban to the exclusion of education and vigilance on the part of prosecutors. I am arguing for both education and legislative action. Prosecutors still need to make the jury aware of the defense's attempt to appeal to implicit and explicit anti-trans bias even if a legislative ban on trans panic is in place.

7. Objection Seven: A Legislative Ban Is Not Needed Since Most Juries Reject the Trans Panic Defense

Another possible objection is that a legislative ban on the trans panic defense is not needed because in most of the recent cases where it was asserted, the jury rejected the defense. ${ }^{346}$ While it may be true that juries rejected the trans panic defense in most of the recent trans panic cases that we know about, there are probably many more trans panic cases that are not known or publicly reported. Not only is it the case that most criminal trials take place in courtrooms throughout the country without any press coverage, most criminal cases are not even tried in open

\footnotetext{
344. See Glionna, supra note 162 (explaining that jurors were "deadlocked over whether the slaying was premeditated and therefore first-degree murder").

345. See supra text accompanying notes 141-42 (discussing the fact that the jury hung in this case).

346. See Wodda \& Panfil, supra note 18, at 942-57, 968 (acknowledging that "most attempts to use the trans* panic defense have been defeated in court").
} 
court. The vast majority of criminal cases end in a guilty plea before a trial even takes place. ${ }^{347}$

Moreover, we know that at least some jurors will find the trans panic defense persuasive, and all it takes is one juror to hang a jury. A juror is likely to find the trans panic defense persuasive if that juror feels a sense of moral outrage when transgender individuals express their gender identity.

A recent study found that conservative jurors are significantly less punitive in cases where the defendant claimed to have acted out of "gay panic" compared to cases where the defendant did not assert a gay panic defense. ${ }^{348}$ The authors of this study theorized that conservative jurors feel less moral outrage towards a defendant who kills a gay man who makes a sexual advance because the gay male victim's behavior violates their moral values. ${ }^{349}$ If this type of leniency by conservative jurors occurs in gay panic cases, it is also likely to occur in trans panic cases where the sense of moral outrage might be even greater since gays and lesbians have achieved a higher degree of acceptance in today's society than trans people. ${ }^{350}$

\section{Objection Eight: A Legislative Ban is Only Effective at Banning the Trans Panic Defense if the Case Goes to Trial}

Finally, one might argue that a legislative ban on the trans panic defense is unlikely to be effective since upwards of ninety-four percent of all criminal cases are resolved by plea bargain as opposed to a trial. ${ }^{351}$ Under this objection, a

347. See Missouri v. Frye, 566 U.S. 134, 143 (2012) (observing that "[n]inety-seven percent of federal convictions and ninety-four percent of state convictions are the result of guilty pleas").

348. See Salerno et al., supra note 108 (finding that conservative jurors were significantly less punitive when a male murder defendant charged with killing a gay man claimed he acted out of gay panic as compared to when the defendant did not claim gay panic).

349. Id. at 27.

350. See Samantha Schmidt, Americans' Views Flipped on Gay Rights. How Did Minds Change so Quickly?, WASH. Post (June 7, 2019), https://beta.washingtonpost.com/local/social-issues/americans-views-flipped-ongay-rights-how-did-minds-change-so-quickly/2019/06/07/ae256016-8720-11e9-98c1-e945ae5db8fb_story.html [https://perma.cc/734U-82AU] (noting that "[a]s recently as 2004, polls showed that the majority of Americans-60 percent- opposed same-sex marriage, while only 31 percent were in favor, according to the Pew Research Center" and that "[t]oday, those numbers are reversed: 61 percent support same-sex marriage, while 31 oppose it"). In contrast, recent polls show that Americans have more negative views about trans people than other groups. See supra note 120 (discussing societal attitudes toward trans people). Despite these changes in social attitudes, being a gay man married to another man is still viewed with disfavor in some parts of the country. See Trip Gabriel, As Buttigieg Courts Black Voters, His Sexuality is a Hurdle, N.Y. TIMES, Oct. 28, 2019, at A22, https://www.nytimes.com/2019/ 10/27/us/politics/pete-buttigieg-south-carolina.html [https://perma.cc/R2CL-S67C] (pointing out that Pete Buttigieg's being a man married to another man is not well favored in the South). Jordan Blair Woods observes that prior to the mid-1970's, when many states had sodomy laws on the books that were primarily enforced against gays, LGBT people involved in the criminal justice system were largely seen as deviant sexual offenders. Today, in contrast, LGBT individuals are largely viewed as innocent victims of hate crimes. Jordan Blair Woods, LGBT Identity and Crime, 105 CAL. L. REV. 667, 705 (2017).

351. Missouri v. Frye, 566 U.S. 134, 143 (2012) (observing that "[n]inety-seven percent of federal convictions and ninety-four percent of state convictions are the result of guilty pleas"). 
legislative ban is a prohibition on a particular trial strategy, and therefore would only work if the case goes to trial.

While it is true that a legislative ban on the trans panic defense aims to limit a particular defense strategy at trial, a ban would also likely encourage defendants to plead guilty and thus help prosecutors secure convictions. Indeed, if the legislative ban recently passed in New York had been in effect in 2013, James Dixon, the man who killed Islan Nettles upon discovering her transgender status, may have been charged with murder rather than first-degree manslaughter in the first place, and may have then agreed to plead guilty to first-degree manslaughter rather than second-degree manslaughter.

Despite these objections, many legislatures have begun the process of enacting legislative bans on gay and trans panic defense strategies. The next Part outlines several of these bans.

\section{Legislative Bans on Gay and Trans Panic Defenses}

This Part starts with the American Bar Association's 2013 resolution asking the federal government and state governments to ban the use of gay and trans panic defense strategies. It then provides an overview of the existing legislative bans on gay and trans panic defenses. Next, it analyzes two proposed legislative bans that are significantly different from the bans that have been enacted and those pending in other states. Finally, this Part concludes by proposing model legislation that borrows the best features from the existing bans.

In August 2013, the American Bar Association ("ABA") passed a resolution urging all states and the federal government to legislatively ban the use of gay and trans panic defenses. ${ }^{352}$ The ABA explained that legislatures should mandate two things: (1) jury instructions on bias and prejudice, and (2) a statement that neither a non-violent sexual advance nor the discovery of a person's sex or gender identity constitutes legally adequate provocation sufficient to mitigate the crime of murder to manslaughter. ${ }^{353}$ Specifically, ABA Resolution 113A urged legislatures to pass legislation:

(a) Requiring courts in any criminal trial or proceeding, upon the request of a party, to instruct the jury not to let bias, sympathy, prejudice, or public opinion influence its decision about the victims, witnesses, or defendants based upon sexual orientation or gender identity; and

(b) Specifying that neither a non-violent sexual advance, nor the discovery of the person's sex or gender identity, constitutes legally adequate

352. The ABA called upon "federal, tribal, state, local and territorial governments to take legislative action to curtail the availability and effectiveness of the 'gay panic' and 'trans panic' defenses." AM. BAR Ass'N H.D. RES. 113A (AM. BAR ASS'N 2013), https://lgbtbar.org/wp-content/uploads/2014/02/Gay-and-Trans-PanicDefenses-Resolution.pdf.

353. Id. 
provocation to mitigate the crime of murder to manslaughter, or to mitigate the severity of any non-capital crime. ${ }^{354}$

\section{A. Existing Legislative Bans on Gay or Trans Panic Defenses}

Following passage of the ABA's 2013 resolution, California became the first state to ban gay and trans panic defenses in 2014. Illinois followed in 2017. Rhode Island was the next state to ban gay and trans panic defenses in 2018. Nevada, New York, Hawaii, Connecticut, and Maine passed similar legislation in 2019. In early 2020, New Jersey and the state of Washington became the latest states to enact bans on gay and trans panic defenses. Similar legislation is pending in several states and in the U.S. Congress.

While all of these legislative bans share the goal of prohibiting criminal defendants from using a gay or trans panic defense strategy to justify, excuse, or mitigate a murder charge, and many of the bills utilize language similar to what is in the California legislation, the bills differ in nuanced and important ways. I discuss these differences below and offer concrete suggestions to strengthen legislative reform in this area.

\section{California (2014)}

In 2014, California became the first state to pass a legislative ban on gay and trans panic defenses. ${ }^{355}$ Assembly Bill 2501 amended California Penal Code Section 192 by adding Subsection (f), specifying:

(1) For purposes of determining sudden quarrel or heat of passion pursuant to subdivision (a), the provocation was not objectively reasonable if it resulted from the discovery of, knowledge about, or potential disclosure of the victim's actual or perceived gender, gender identity, gender expression, or sexual orientation, including under circumstances in which the victim made an unwanted nonforcible romantic or sexual advance towards the defendant, or if the defendant and the victim dated or had a romantic or sexual relationship. Nothing in this section shall preclude the jury from considering all relevant facts to determine whether the defendant was in fact provoked for purposes of establishing subjective provocation.

(2) For purposes of this subdivision, 'gender' includes a person's gender identity and gender-related appearance and behavior regardless of whether that appearance or behavior is associated with the person's gender as determined at birth. ${ }^{356}$

355. See Parker Marie Molloy, California Becomes First State to Ban Gay, Trans 'Panic' Defenses, ADVOCATE (Sept. 29, 2014), https://www.advocate.com/crime/2014/09/29/california-becomes-first-state-bangay-trans-panic-defenses [https://perma.cc/Z2YA-66GN].

356. CAL. Penal CoDE $§ 192(f)(1),(2)(2019)$. 
In stating that provocation is not objectively reasonable if it is the result of the discovery of, knowledge about, or potential disclosure of the victim's gender, gender identity, or sexual orientation, Subsection (f)(1) makes a normative assessment about whether what the defendant claims provoked him constitutes "legal adequate provocation." Such determinations are usually left to the jury in jurisdictions that follow the modern approach. Some might argue, as I once did, that this kind of assessment should be left to the jury, rather than the legislature, because reasonable minds can disagree as to whether it is reasonable for a defendant to be provoked into a heat of passion by a non-violent sexual advance or the discovery that the victim's sex does not align with her gender identity.

As discussed above, however, the law has always played a role in defining what counts as legally adequate provocation. At early common law, for example, the law specified a limited number of categories of actions that constituted legally adequate provocation. ${ }^{357}$ If one was provoked into a heat of passion by a person, act, or event that fell outside one of these categories, one could not receive the provocation mitigation.

Even today, most jurisdictions abide by the mere words rule, which is that words alone, no matter how offensive or provocative, can never constitute legally adequate provocation. ${ }^{358}$ In putting mere words outside the scope of what constitutes legally adequate provocation, the law makes a statement that it is not normatively reasonable to be provoked by mere words.

Other examples of the law defining what constitutes legally adequate provocation exist. In Minnesota, for example, a defendant may not claim the provocation mitigation if what provoked him was a crying baby because the legislature has banned such arguments. ${ }^{359}$ Similarly, in Maryland, a defendant may not claim the provocation mitigation by claiming that the discovery of his or her spouse in the act of adultery provoked the defendant into a heat of passion because the Maryland legislature has decided that this does not constitute legally adequate provocation. ${ }^{360}$

California's law banning gay and trans panic defense arguments is just another example of the law defining the contours of what constitutes legally adequate

357. See supra text accompanying notes 93-94.

358. See United States v. Slager, 912 F.3d 224, 236 (4th Cir. 2019) (noting that "mere words" generally constitute inadequate provocation to negate a finding of malice) (internal quotations and citation omitted); Stevens v. McBride, 489 F.3d 883, 892 (7th Cir. 2007) (noting that "words alone cannot constitute sufficient provocation to give rise to a finding of sudden heat warranting an instruction on voluntary manslaughter") (internal quotation and citation omitted).

359. MinN. STAT. § 609.20(1) (2019) ("Whoever . . intentionally causes the death of another person in the heat of passion provoked by such words or acts of another as would provoke a person of ordinary self-control under like circumstances" is guilty of manslaughter in the first-degree "provided that the crying of a child does not constitute provocation").

360. MD. CODE ANN., CRIM. LAW § 2-207(b) (2019) (providing that “[ $t$ ] he discovery of one's spouse engaged in sexual intercourse with another does not constitute legally adequate provocation for the purpose of mitigating a killing from the crime of murder to voluntary manslaughter even though the killing was provoked by that discovery"). 
provocation. Subsection (f)(1) correctly focuses the factfinder's attention on whether the provocation resulted from the discovery of, knowledge about, or disclosure of the victim's gender, gender identity, gender expression, or sexual orientation. It makes sense to preclude the provocation defense in these cases since it is clearly unreasonable to lose one's self-control after learning that another person is gay or a transgender individual. One should not be excused for physical violence against another person due to their sexual orientation or gender identity.

Subsection (f)(1) acknowledges that a defendant might have discovered that the victim was gay if the victim made an unwanted, non-forcible romantic or sexual advance toward the defendant. Likewise, the defendant might have discovered that the victim was a transgender woman in the course of a romantic or sexual relationship. The prohibition, however, only applies if the alleged provocation resulted from the discovery of, knowledge about, or disclosure of the victim's gender identity or sexual orientation. Thus, even though most people assume the opposite when they hear that a legislative ban on gay and trans panic defenses has been enacted, California's legislation does not bar a defendant from arguing that he was provoked into a heat of passion by a non-violent homosexual advance. Subsection (f)(1) simply says that a defendant's claimed provocation is not objectively reasonable and therefore is not legally adequate if it stemmed from the defendant's discovery of, knowledge about, or potential disclosure of the victim's gender identity or sexual orientation.

Subsection (f)(1) also makes clear that the jury may consider all relevant facts in assessing whether the defendant was in fact provoked, providing that "[n]othing in this section shall preclude the jury from considering all relevant facts to determine whether the defendant was in fact provoked for purposes of establishing subjective provocation." 361 In other words, if the defendant claims he was provoked into a heat of passion by the discovery that the victim was a transgender woman, the jury can consider this as part of the inquiry into whether the defendant was actually provoked into a heat of passion, one of the requirements for a heat of passion claim. This kind of information, however, cannot be used to show the defendant was reasonably provoked into a heat of provocation because Subsection (f)(1) explicitly states that it is not reasonable to be provoked into a heat of passion by the discovery of or knowledge of an individual's gender identity or sexual orientation. ${ }^{362}$ Even if the jury believes the defendant was actually provoked into a heat of passion, it may not return a verdict of voluntary manslaughter unless it disregards the law because what the defendant claims provoked him is not legally adequate provocation under the new law.

The jury may, however, use the fact that the defendant was actually provoked to reduce a first-degree murder charge to second-degree murder. The "[n]othing in this section shall preclude the jury" language in Subsection (f)(1) enables a

361. Cal. Penal Code $§ 192(f)(1)$ (2019).

362. $I d$. 
defendant charged with first-degree murder to use the fact that he was actually provoked to support a second-degree murder conviction. The defendant can argue that because he was actually provoked into a heat of passion, he could not have engaged in the thoughtful premeditation and deliberation needed for a first-degree murder conviction. ${ }^{363}$

\section{Illinois (2017)}

In May 2017, Illinois became the second state to legislatively ban gay and trans panic defenses when the Illinois legislature amended its Criminal Code to disallow the discovery, knowledge, or disclosure of the victim's sexual orientation as a mitigating factor for first-degree murder. ${ }^{364}$ At first glance, it appears that Illinois does not prohibit murder defendants from asserting a trans panic defense since the legislation references only sexual orientation, not gender identity. ${ }^{365}$ In fact, however, the legislation does prohibit the trans panic defense strategy since it incorporates by reference the Illinois Human Rights Act, which provides:

"Sexual orientation" means actual or perceived heterosexuality, homosexuality, bisexuality, or gender-related identity, whether or not traditionally associated with the person's designated sex at birth. "Sexual orientation" does not include a physical or sexual attraction to a minor by an adult. ${ }^{366}$

Unlike in most jurisdictions where the provocation defense mitigates a murder charge down to voluntary manslaughter, in Illinois, legally adequate provocation

363. Apparently, the California Attorneys for Criminal Justice, a group that represents the interests of the criminal defense bar in California, lobbied to get this language added to the California legislation so it would be clear that subjective provocation could help a first-degree murder defendant trying to show he lacked the specific intent required for conviction. Telephone Conversation with William DuBois, attorney for Jose Merel (November 2, 2019).

364. 720 Ill. Comp. Stat. 5/9-1(c) (2020). The Illinois ban passed unanimously. See Sophia Tareen, Activists to Copy Illinois 'Gay Panic Defense' Ban Elsewhere, Assoc. Press (Dec. 28, 2017), https://apnews.com/ 9dc24f2031c8465081d790152f6efbd8 [https://perma.cc/V9QH-CMEF] (noting that "[a]fter a lackluster attempt in 2016, the Illinois ban sailed through the Legislature in May with no opposition and Republican Gov. Bruce Rauner signed it into law without comment”); Richard Gonzales, Illinois to Ban 'Gay Panic Defense' In New Year, NPR (Dec. 28, 2017), https://www.npr.org/sections/thetwo-way/2017/12/28/574453009/illinois-to-bangay-panic-defense-in-new-year [https://perma.cc/CF52-377L] (reporting that "[o]n Monday, Illinois will become the second state to ban the so-called gay panic defense in cases in which a murder defendant tries to justify his violence as a reaction to learning that the victim was gay"); see also 2017 LGBTQ Legislative Agenda, EQUAL. ILLINOIS, https://www.equalityillinois.us/2017-legis [https://perma.cc/NUT6-UXOR]; Press Release, Equality Illinois, Governor Rauner Approves Ban on Use of LGBTQ Panic Defense, https://www.equalityillinois.us/ about-us/press-releases/panic-defense-ban [https://perma.cc/7W25-T7QL].

365. 720 Ill. COMP. StAT. 5/9-1(c).

366. Illinois Human Rights Act, 775 ILl. COMP. STAT. 5/1-103 (2020) (emphasis added), http://ilga.gov/ legislation/ilcs/ilcs4.asp?DocName $=077500050 H$ Art $\% 2 E+1 \& A c t I D=2266 \&$ ChapterID $=64 \&$ SeqStart $=100000 \&$ SeqEnd=600000. I thank Anthony Kreis, Visiting Assistant Professor of Law, Chicago-Kent College of Law, Illinois Institute of Technology, for assisting me with the interpretation of the Illinois ban. Professor Kreis was instrumental in getting the Illinois legislation enacted. 
mitigates a first-degree murder charge to second-degree murder. ${ }^{367}$ Under the Illinois Criminal Code, a person commits second-degree murder when he or she commits first-degree murder and certain mitigating factors are present. ${ }^{368}$ Relevant to the trans panic defense, one mitigating factor is "acting under a sudden and intense passion resulting from serious provocation[.]"369

Before 2017, Illinois defined "serious provocation," i.e., legally adequate provocation, as "conduct sufficient to excite an intense passion in a reasonable person[.]"370 In 2017, the legislature amended its Criminal Code to ban gay and trans panic defenses by adding the following language to Section 9-2(b):

$[\mathrm{P}]$ rovided, however, that an action that does not otherwise constitute serious provocation cannot qualify as serious provocation because of the discovery, knowledge, or disclosure of the victim's sexual orientation as defined in Section 1-103 of the Illinois Human Rights Act. ${ }^{371}$

What this means is that in Illinois, in contrast to California, neither a gay nor a trans panic argument can be used to mitigate a first-degree murder charge down to second-degree murder.

Confusingly, while Section 9-2(a) follows the modern reasonable person test for provocation for defendants charged with first-degree murder seeking a mitigation to second-degree murder, ${ }^{372}$ another section of the Illinois Criminal Code adopts language from the MPC's extreme mental or emotional disturbance defense for defendants charged with first-degree murder who are facing a possible death sentence. Section 9-1(c)(2) lists as a mitigating factor for not elevating first-degree murder to capital murder the fact that "the murder was committed while the defendant was under the influence of extreme mental or emotional disturbance, although not such as to constitute a defense to prosecution[.]" ${ }^{373}$ In 2017, Illinois added language to Section 9-1(c) barring "the discovery, knowledge, or disclosure of the victim's sexual orientation" as a mitigating factor. ${ }^{374}$ Because the Illinois statute incorporates by reference the Illinois Human Rights Act's definition of

367. See 720 Ill. Comp. Stat. 5/9-2(a)(1) (2018). In 1986, the Illinois state legislature enacted Public Act 84 1450, amending Section 9-2 of the Illinois Criminal Code of 1961, changing the offense of murder to first-degree murder and abolishing the offense of voluntary manslaughter, replacing it with the offense of second-degree murder. See People v. Jeffries, 646 N.E.2d 587, 590-91 (Ill. 1995).

368. See 720 Ill. COMP. Stat. 5/9-2(a)(1).

369. Id.

370. See 720 Ill. Comp. Stat. 5/9-2(b) (2017). Confusingly, the Illinois courts still apply the early common law approach under which legally adequate provocation was limited to a handful of specified categories. See People v. McDonald, 77 N.E.3d 26, 42 (IIl. 2016) ("The only categories recognized by this court to constitute serious provocation are substantial physical injury or substantial physical assault, mutual quarrel or combat, illegal arrest, and adultery with the offender's spouse.").

371. 720 Ill. COMP. StAt. 5/9-2(b) (2018).

372. 720 ILl. COMP. STAT. 5/9-2(a).

373. 720 ILl. COMP. Stat. 5/9-1(c)(2) (2020).

374. Id. §5/9-1(c). 
sexual orientation, which includes gender identity, ${ }^{375}$ a defendant charged with capital murder in Illinois may not assert a gay or trans panic argument as a reason for the jury to recommend life rather than imposition of the death penalty.

3. Rhode Island (2018)

In 2018, Rhode Island passed legislation similar to California's, amending Chapter 12-17 of the Rhode Island General Laws entitled "Trials" by adding a new Section 12-17-17. ${ }^{376}$ The new Section explains that provocation is not objectively reasonable if:

... it resulted solely from the discovery of, knowledge about, or potential disclosure of the victim's actual or perceived gender, gender identity, gender expression, or sexual orientation, including under circumstances in which the victim made an unwanted, non-forcible romantic or sexual advance toward the defendant, or if the defendant and victim dated or had a romantic relationship. ${ }^{377}$

Notably, Rhode Island goes further than California since it does not simply prohibit the use of gay and trans panic arguments to support claims of provocation, but also prohibits the use of gay and trans panic arguments to support claims of diminished capacity and self-defense. Newly added Section 12-17-18, entitled "Restrictions on the defense of diminished capacity," provides:

A defendant does not suffer from reduced mental capacity based solely on the discovery of, knowledge about, or potential disclosure of the victim's actual or perceived gender, gender identity, gender expression, or sexual orientation, including under circumstances in which the victim made an unwanted, nonforcible romantic or sexual advance toward the defendant, or if the defendant and victim dated or had a romantic or sexual relationship. ${ }^{378}$

Newly added Section 12-17-19, entitled "Restrictions on the defense of selfdefense," provides:

A person is not justified in using force against another based solely on the discovery of, knowledge about, or potential disclosure of the victim's actual or perceived gender, gender identity, gender expression, or sexual orientation, including under circumstances in which the victim made an unwanted, nonforcible romantic or sexual advance toward the defendant, or if the defendant and victim dated or had a romantic or sexual relationship. ${ }^{379}$

375. See text accompanying note 368 .

376. 12 R.I. GEN. LAWs $§ 12-17-17$ (2018).

377. Id. (emphasis added).

378. 12 R.I. GEN. LAwS § 12-17-18 (2018) (emphasis added).

379. 12 R.I. GEN. LAWS $§ 12-17-19$ (2018) (emphasis added). 
The Rhode Island legislature explained that its purpose in enacting these provisions was not only to "restrict the use of a victim's gender or sexual orientation as a defense by any defendant claiming provocation, diminished capacity or selfdefense," but also to "prohibit the court from allowing such information into evidence." ${ }^{380}$ In specifying that courts are prohibited from allowing such information into evidence, the Rhode Island legislation goes further to protect against defendants trying to utilize gay and trans panic arguments than either California or Illinois. ${ }^{381}$

While Rhode Island significantly limits a defendant's ability to mount a gay or trans panic defense strategy, it is more helpful to defendants than the California legislation in one respect. In including the term "solely" in all three newly added provisions, Rhode Island permits a defendant to argue provocation, mental incapacity, or self-defense based upon the discovery of the victim's actual or perceived gender, gender identity, gender expression, or sexual expression as long as the defendant can point to some other reason for his being provoked into a heat of passion (or his loss of mental capacity, or his use of force in self-defense) in addition to the discovery of the victim's gender, gender identity, gender expression or sexual expression. ${ }^{382}$ It is unclear whether this was simply an oversight or whether the Rhode Island legislature purposely included the word "solely" to counter criminal defense bar objections and ensure passage of the legislation.

\section{Nevada (2019)}

In May 2019, Nevada became the fourth state in the United States to pass legislation banning gay and trans panic defenses. ${ }^{383}$ Section 193.225 provides that, in the context of a defendant asserting a provocation defense, the alleged heat of passion or provocation is not objectively reasonable if:

380. Id. (Explanation by the Legislative Council of an Act Relating to Criminal Procedure-Trials).

381. In limiting the evidence that may be admitted at trial, the Rhode Island legislature may have been responding to calls for reform in this area. In 2015, for example, Kelly Strader and others proposed a "gay shield" rule of evidence that would limit the trial court's ability to admit evidence designed to provoke homophobic and transphobic responses in jurors. See Strader et al., supra note 130, at 1474, 1526.

382. It is unclear whether this was simply an oversight by the legislature or whether the legislature purposely included the word "solely" to give murder defendants the ability to make a gay or trans panic argument to the jury. There is very little legislative history on this question. See Omar T. Russo, How to Get Away with Murder: The "Gay Panic" Defense, 35 Touro L. Rev. 811, 835 (2019) (noting that one legislator, "Justin Price, expressed concerns that such a ban would be harmful because it permits the withholding of information (the victim's sexual orientation or gender identity) from the jury and, thus, prevents them from making a sound decision”); Katherine Gregg, R.I. House Votes to End 'Gay or Trans' Panic Defense, Providence J. (May 22, 2018), https://www.providencejournal.com/news/20180522/ri-house-votes-to-end-gay-or-trans-panic-defense [https://perma.cc/2USR-L86E] (reporting that Rep. Justin Price was quoted as indicating his concern about withholding from jurors "all the information as far as what happened during an altercation, I don't think that they [can] make a sound decision," during the brief floor discussion).

383. Nevada Just Banned Gay and Trans 'Panic' Defenses—Which State Will Be Next?, LGBT BAR (May 17, 2019), https://lgbtbar.org/bar-news/nevada-just-banned-gay-and-trans-panic-defenses-which-state-will-be-next [https://perma.cc/VH73-MSFR] (noting that SB 97 "passed in both houses, and on May 16, [2019], Governor Sisolak signed the bill into law"). 
[I]t resulted from the discovery of, knowledge about or potential disclosure of the actual or perceived sexual orientation or gender identity or expression of the victim, including, without limitation, under circumstances in which the victim made an unwanted nonforcible romantic or sexual advance towards the defendant, or if the defendant and victim dated or had a romantic or sexual relationship. ${ }^{384}$

Like Rhode Island, Nevada also prohibits a defendant from using trans panic to support a claim of self-defense, stating:

A person is not justified in using force against another person based on the discovery of, knowledge about or potential disclosure of the actual or perceived sexual orientation or gender identity or expression of the victim, including, without limitation, under circumstances in which the victim made an unwanted nonforcible romantic or sexual advance towards the defendant, or if the defendant and victim dated or had a romantic or sexual relationship. ${ }^{385}$

Nevada, however, does not bar a defendant from basing a diminished capacity or temporary insanity defense on the discovery of, knowledge about, or potential disclosure of the victim's actual or perceived sexual orientation or gender identity as does Rhode Island. ${ }^{386}$

Also unlike Rhode Island, Nevada does not include the word "solely" in any of its new provisions, and thus prevents a defendant from making a gay or trans panic argument by alleging that something in addition to the discovery that the victim was a gay man or a transgender woman, such as an allegedly provocative sexual advance, provoked him into a heat of passion or caused him to reasonably believe he needed to use deadly force in self-defense. In this way, Nevada is not as defendant-friendly as Rhode Island.

\section{New York (2019)}

On June 19, 2019, New York became the fifth state to ban gay and trans panic defense strategies when the New York Assembly voted to enact State Assembly Bill A8375. ${ }^{387}$ Governor Cuomo had a huge influence on the passage of this legislative ban, publicly urging the New York legislature to pass this legislation. ${ }^{388}$

384. NEV. ReV. STAT. § 193.225(1) (2019).

385. Id. $\S 193.225(2)$.

386. See 12 R.I. GEN. LAWS $§ 12-17-18$ (2018).

387. Assemb. 8375, 2019-2020 Reg. Sess. (N.Y. 2019); N.Y. Penal Law § 125.25 (2019).

388. See NY Gov. Cuomo: Eliminate 'Gay Panic' Defense, U.S. News (June 2, 2019), https://www.usnews. com/news/best-states/new-york/articles/2019-06-02/ny-gov-cuomo-eliminate-gay-panic-defense [https://perma. cc/6BLK-VP86]; Denis Slattery, Gov. Cuomo Makes Progressive Push for LGBTQ Bills Allowing Surrogacy and Ending "Gay Panic" Defense as End of Legislative Session Nears, N.Y. DAILY NEWs (May 31, 2019), https:// www.nydailynews.com/news/politics/ny-cuomo-progressive-lgbtq-surrogacy-gay-panic-20190531-vtjnii2y25by 7ija5iskv5ajti-story.html [https://perma.cc/EDS5-8SWZ]. 
The bill had stalled for years prior to this point. ${ }^{389}$

New York follows the MPC's extreme mental or emotional disturbance approach to provocation. Under New York law, any defendant charged with murder in the second degree who acts under the influence of an extreme emotional disturbance for which there is a reasonable explanation or excuse may be convicted of the lesser offense of manslaughter. ${ }^{390}$ The reasonableness of the defendant's explanation or excuse is "to be determined from the viewpoint of a person in the defendant's situation under the circumstances as the defendant believed them to be." 391

Assembly Bill 8375 amended Section 125.25 of the New York Penal Code by dividing Section 125.25(a) into two parts and adding a new Subsection (ii) to Subsection (a), providing:

It shall not be a "reasonable explanation or excuse" pursuant to subparagraph (i) of this paragraph when the defendant's conduct resulted from the discovery, knowledge or disclosure of the victim's sexual orientation, sex, gender, gender identity, gender expression or sex assigned at birth[.] $]^{392}$

In passing this legislation, New York follows the language of the preceding bans, focusing on whether the defendant's claim of extreme emotional disturbance stemmed from the discovery, knowledge, or disclosure of the victim's sexual orientation, gender identity, or sex assigned at birth. Notable is the absence of the "[n]othing in this section shall preclude the jury from considering all relevant facts to determine whether the defendant was in fact provoked for purposes of establishing subjective provocation" language found in California's legislation. ${ }^{393}$ This is probably due to the fact that the extreme emotional disturbance defense utilizes a subjective standard of reasonableness, whereas the modern test for provocation requires a showing that the defendant was actually provoked and the reasonable person in the defendant's shoes would have been provoked as well.

\section{Hawaii (2019)}

On June 21, 2019, Hawaii enacted a ban on the gay and trans panic defenses. Like New York, Hawaii follows the MPC's approach to provocation, allowing defendants charged with either murder or attempted murder to assert as an affirmative defense that at the time of the crime, the defendant was "under the influence of an extreme mental or emotional disturbance for which there is a reasonable

389. See Dan M. Clark, Deal Is Reached to End 'Gay Panic' Defense in NY, Cuomo Says, N.Y. L.J. OnLINE (June 17, 2019), https://www.law.com/newyorklawjournal/2019/06/17/deal-is-reached-to-end-gay-panic-defensein-ny-cuomo-says/?slreturn=20190815182031 [https://perma.cc/H4SG-VYW2].

390. N.Y. PENAL LAW $§ 125.20(2), 125.25(1)(a)(i)(2019)$.

391. N.Y. PENAL LAW $§ 125.25(1)$ (a)(i).

392. N.Y. PENAL LAW § 125.25(1)(a)(ii). Assembly Bill 8375 also amended Sections 125.26 and 125.27 of the New York Penal Code by adding the same language to these provisions. N.Y. PENAL LAW $\S \S 125.26(3)$ (a) (ii), 125.27(2)(a)(ii) (2019).

393. Cal. Penal Code $§ 192(f)(1)$ (2019). 
explanation." ${ }^{\text {"394 }}$ As in most jurisdictions that follow the MPC approach to provocation, Hawaii provides that "[ $\mathrm{t}]$ he reasonableness of the explanation shall be determined from the viewpoint of a reasonable person in the circumstances as the defendant believed them to be[.]"395

House Bill 711 added the following language to Hawaii's extreme mental or emotional disturbance defense:

[A]n explanation that is not otherwise reasonable shall not be determined to be reasonable because of the defendant's discovery, defendant's knowledge, or the disclosure of the other person's actual or perceived gender, gender identity, gender expression, or sexual orientation, including under circumstances in which the other person made an unwanted nonforcible romantic or sexual advance toward the defendant, or in which the defendant and the other person dated or had a romantic relationship. If the defendant's explanation includes the discovery, knowledge, or disclosure of the other person's actual or perceived gender, gender identity, gender expression, or sexual orientation, the court shall instruct the jury to disregard biases or prejudices regarding the other person's actual or perceived gender, gender identity, gender expression, or sexual orientation in reaching a verdict. ${ }^{396}$

In prohibiting the defendant from arguing that the discovery, knowledge, or disclosure of the victim's gender, gender identity, gender expression, or sexual orientation constitutes a reasonable explanation, the Hawaii legislation tracks the language used in California, Rhode Island, Nevada, and New York. Hawaii, however, goes further than these states in requiring the judge to instruct the jury to disregard biases or prejudices regarding the victim's actual or perceived gender, gender identity, gender expression, or sexual orientation in reaching a verdict if the defendant's explanation for his extreme mental or emotional disturbance includes the discovery, knowledge or disclosure of any of the above. ${ }^{397}$

\section{Connecticut (2019)}

Also on June 21, 2019, Connecticut enacted its own legislation banning gay and trans panic defenses. New Section 53a-13(b)(2) provides:

No defendant may claim as a defense under this section that such mental disease or defect was based solely on the discovery of, knowledge about or potential disclosure of the victim's actual or perceived sex, sexual orientation or gender identity or expression, including under circumstances in which the victim made an unwanted, nonforcible, romantic or sexual advance toward the defendant, or if the defendant and victim had dated or had a romantic relationship. ${ }^{398}$

394. Haw. ReV. Stat. § 707-702(2) (2019).

395. Id.

396. Id.

397. Id.

398. See Conn. Gen. Stat. § 53a-13(b)(2) (2019) (emphasis added). 
Section 53a-16 now includes the following language:

Justification as a defense does not include provocation that resulted solely from the discovery of, knowledge about or potential disclosure of the victim's actual or perceived sex, sexual orientation or gender identity or expression, including under circumstances in which the victim made an unwanted, nonforcible, romantic or sexual advance toward the defendant, or if the defendant and victim dated or had a romantic relationship. ${ }^{399}$

New Section 53a-18(b) provides:

No person is justified in using force upon another person which would otherwise constitute an offense based solely on the discovery of, knowledge about or potential disclosure of the victim's actual or perceived sex, sexual orientation or gender identity or expression, including under circumstances in which the victim made an unwanted, nonforcible, romantic or sexual advance toward the defendant, or if the defendant and victim dated or had a romantic relationship. ${ }^{400}$

In prohibiting defendants from relying on "the discovery of, knowledge about or potential disclosure of the victim's actual or perceived sex, sexual orientation or gender identity or expression" 401 as the basis for a mental defect defense, provocation, or self-defense, Connecticut follows the other states that have passed legislative bans on gay and trans panic. Connecticut follows Rhode Island in extending the ban beyond the defense of provocation to mental disease or defect defenses and the defense of self-defense. ${ }^{402}$ Connecticut also follows Rhode Island in including the word "solely" in each provision. ${ }^{403}$ This means that a defendant may argue provocation, mental disease or defect, or self-defense even if the discovery of the victim's gender identity or sexual orientation was part of what motivated him as long as he can point to something else that provoked him, caused his mental disease or defect, or caused him to use physical force against the victim.

\section{Maine (2019)}

On June 21, 2019, Maine enacted a ban on gay and trans panic defenses, amending its insanity statute to include the following language:

An actor does not suffer from an abnormal condition of the mind based solely on the discovery of, knowledge about or potential disclosure of the victim's actual or perceived gender, gender identity, gender expression or sexual orientation, including under circumstances in which the victim made an unwanted

399. Conn. Gen. Stat. § 53a-16 (2019) (emphasis added).

400. Conn. Gen. Stat. § 53a-18(b) (2019) (emphasis added).

401. Id.

402. See Conn. Gen. Stat. § 53a-13.

403. See Conn. Gen. StAT. §§ 53a-13(b)(2), 53a-16, 53a-18(b). 
nonforcible romantic or sexual advance toward the actor or in which the actor and victim dated or had a romantic or sexual relationship. ${ }^{404}$

\section{Maine also enacted the following as Section 17-A MRSA $§ 108(3)$ :}

A person is not justified in using force against another based solely on the discovery of common knowledge about or potential disclosure of the victim's actual or perceived gender, gender identity, gender expression or sexual orientation, including under circumstances in which the victim made an unwanted nonforcible romantic or sexual advance toward the person or in which the person and victim dated or had a romantic or sexual relationship. ${ }^{405}$

Additionally, Maine amended its provocation statute to include the following language:

For purposes of determining whether extreme anger or extreme fear was brought about by adequate provocation, the prosecution was not adequate if it resulted solely from the discovery of, knowledge about or potential disclosure of the victim's actual or perceived gender, gender identity, gender expression or sexual orientation, including under circumstances in which the victim made an unwanted non-forcible romantic or sexual advance toward the person or in which the person and victim dated or had a romantic or sexual relationship. ${ }^{406}$

In disallowing defendants from arguing that "the discovery of, knowledge about or potential disclosure of the victim's actual or perceived gender, gender identity, gender expression or sexual orientation" constitutes adequate provocation, Maine follows the other states with legislative bans on the gay and trans panic defense. ${ }^{407}$ Like Rhode Island and Connecticut, Maine's ban extends to defendants asserting a mental defect defense or self-defense. ${ }^{408}$ Maine also follows Rhode Island and Connecticut in using the word "solely" in its ban, which means that a defendant may still make a gay or trans panic argument as long as it is not the sole basis for his claim of provocation, mental defect, or self-defense. ${ }^{409}$

\section{New Jersey (2020)}

In January 2020, New Jersey became the ninth state to pass legislation banning the gay and trans panic defenses. ${ }^{410}$ This legislation added the following provision to N.J.S. 2C:11-4:

404. Me. Rev. Stat. tit. 17-A, § 38 (2019) (emphasis added).

405. ME. ReV. STAT. tit. 17-A, § 108(3) (2019) (emphasis added).

406. ME. Rev. StAT. tit. 17-A, § 201(4) (2019) (emphasis added).

407. Id. $\S 38,108,201$.

408. Id. $\S 38,201$.

409. Id. $\S 38,108,201$.

410. See Cassandra Maas, New Jersey Passes Law Banning 'Gay Panic' Murder Defense, JuRIST (Jan. 21, 2020), https://www.jurist.org/news/2020/01/new-jersey-passes-law-banning-gay-panic-murder-defense/\# [https:// perma.cc/XP4T-UUDT]. The bill was signed into law on January 21, 2020. See Tim Fitzsimons. N.J. Bans Gay and 
The discovery of, knowledge about, or potential disclosure of the homicide victim's actual or perceived gender identity or expression, or affectional or sexual orientation, which occurred under any circumstances, including but not limited to circumstances in which the victim made an unwanted, non-forcible romantic or sexual advance toward the actor, or if the victim and actor dated or had a romantic or sexual relationship, shall not be reasonable provocation pursuant to this paragraph. ${ }^{411}$

The New Jersey legislation is similar to language in California's ban, except it does not provide, as California does, that "[n]othing in this section shall preclude the jury from considering all relevant facts to determine whether the defendant was in fact provoked for purposes of establishing subjective provocation." 412 Like California, New Jersey's ban is limited to the heat of passion/provocation defense and does not extend to diminished capacity and self-defense.

\section{Washington (2020)}

On February 26, 2020, lawmakers in the state of Washington passed "[a] measure prohibiting homicide defendants from claiming a defense based on panic over a victim's sexual orientation or gender identity[.]" "413 The following sections were added to chapters 9A.08 and 9A.16 RCW, respectively:

Sec. 1. A defendant does not suffer from diminished capacity based on the discovery of, knowledge about, or potential disclosure of the victim's actual or perceived gender, gender identity, gender expression, or sexual orientation, including under circumstances in which the victim made an unwanted nonforcible romantic or sexual advance towards the defendant, or in which the defendant and victim dated or had a romantic or sexual relationship.

Sec. 2. A person is not justified in using force against another based on the discovery of, knowledge about, or potential disclosure of the victim's actual or perceived gender, gender identity, gender expression, or sexual orientation, including under circumstances in which the victim made an unwanted nonforcible romantic or sexual advance toward the defendant, or in which the defendant and victim dated or had a romantic or sexual relationship. ${ }^{414}$

This bill was signed into law by Governor Jay Inslee on March 5, 2020. ${ }^{415}$ In applying its ban to diminished capacity and self-defense (justified force),

Transgender 'Panic Defenses', NBC NEws (Jan. 22, 2020), https://www.nbcnews.com/feature/nbc-out/n-j-bansgay-transgender-panic-defenses-n1120416 [https://perma.cc/9EWV-Y939].

411. N.J. REV. STAT. § 2C:11-4(b)(2) (2020).

412. Cal. Penal Code $§ 192(f)(1)(2019)$.

413. Washington Passes Ban on Gay and Trans Panic Defenses for Homicide, NBC News (Feb. 28, 2020), https://www.nbcnews.com/feature/nbc-out/washington-passes-ban-gay-trans-panic-defenses-homicide-n1144931 [https://perma.cc/37DG-3V92].

414. Nikki Kuhnhausen Act, H.R. 1687, 66th Leg., Reg. Sess. (Wash. 2020) (effective June 11, 2020).

415. Office of Sec'y of State of Wash., Certification of Enrollment for Engrossed House Bill 1687 (2020). 
Washington follows Rhode Island, Connecticut, and Maine. Strangely, the express language of the statute does not appear to apply to the defense of provocation. ${ }^{416}$

\section{B. Pending Legislation}

In addition to the legislative bans discussed above, bills proposing to ban gay and trans panic defenses have been introduced but not yet passed in Colorado, ${ }^{417}$ the District of Columbia, ${ }^{418}$ Georgia, ${ }^{419}$ Iowa, ${ }^{420}$ Maryland, ${ }^{421}$ Massachusetts, ${ }^{422}$ Minnesota, ${ }^{423}$ New Mexico, ${ }^{424}$ Pennsylvania, ${ }^{425}$ Texas, ${ }^{426}$ Wisconsin, ${ }^{427}$ and the U.S. Congress ${ }^{428}$ at least as of March 1, 2020. ${ }^{429}$ A discussion of the ways in which two of these bills differ significantly from the already enacted bills, rather than a detailed analysis of each additional bill, is below.

416. Section 2 of the bill bars a defendant from claiming he was justified in using force against the victim. The provocation defense, however, is usually considered a partial excuse, rather than a justification. See supra note 146.

417. H.R. 1307, 72nd Gen. Assemb., 2nd Reg. Sess. (Colo. 2020).

418. Legis. Summary, D.C. Council B22-0102, 22d Council, 2017-2018 Sess. (D.C. 2017).

419. H.R. 931, 2017-2018 Gen. Assemb., Reg. Sess. (Ga. 2018) (seeking to "amend Code Section 16-5-2 of the Official Code of Georgia Annotated, relating to voluntary manslaughter, so as to exclude the discovery or disclosure of an individual's sexual orientation or gender identity as being serious provocation in the context of voluntary manslaughter").

420. H.R. 693, 88th Gen. Assemb. (Iowa 2020).

421. H.R. 488, 2020 Gen. Assemb., 441st Sess. (Md. 2020); S. 554, 2020 Gen. Assemb., 441st Sess. (Md. 2020).

422. S. 870, 191st Gen. Court. (Mass. 2019) (proposing to add the following language to Section 13 of Chapter 265: "For the purposes of determining the presence of mitigating circumstances in the context of a homicide, the discovery of, knowledge about, or potential disclosure of an individual's actual or perceived gender, gender identity, gender expression, or sexual orientation, including under circumstances in which the victim made an unwanted non-forcible romantic or sexual advance towards the defendant, or the defendant dated or had a romantic or sexual relationship, shall not be considered reasonable provocation").

423. S. 233, 2017-2018 Leg., 90th Sess. (Minn. 2018) (attempting to amend Minnesota's provisions on selfdefense, intoxication and manslaughter in the first-degree to provide, inter alia, that "[i]t is not a defense to a crime that the defendant acted based on the discovery of, knowledge about, or potential disclosure of the victim's actual or perceived sexual orientation, including gender identity and expression").

424. S. 159, 54th Leg., Reg. Sess. (N.M. 2019).

425. S. 1244, 2017-2018 Gen. Assemb., Reg. Sess. (Pa. 2018) (attempting to amend the Pennsylvania criminal code to state that conduct sufficient to excite an intense passion in a reasonable person "does not include the discovery, knowledge or potential disclosure of a victim's actual or perceived gender identity or expression or sexual orientation").

426. H.R. 3281, 86th Leg., Reg. Sess. (Tex. 2019) (seeking to amend Chapter 10 of Title 2 of the Texas Penal Code to state, inter alia, that " $[\mathrm{t}] \mathrm{he}$ use of force against another is not justified and an actor does not reasonably believe that the use of force is immediately necessary if the use of force occurs in response to: (1) the actor's discovery or knowledge of, or the victim's disclosure or potential disclosure of, the gender identity or sexual orientation of the victim; or (2) a nonviolent romantic or sexual advance made by the victim towards the actor").

427. Assemb. 436, 104th Leg., 2019-2020 Reg. Sess. (Wis. 2019); S. 393, 104th Leg., 2019-2020 Reg. Sess. (Wis. 2019).

428. The Gay and Trans Panic Defense Prohibition Act of 2018, H.R. 6358 \& S. 3188, 115th Cong. (2018).

429. This should not be taken as an exhaustive list. There may be other pending bills not listed above. 


\section{Washington, DC (pending)}

On February 7, 2017, D.C. Councilman David Grosso introduced legislation that would establish limits on defense arguments that seek to excuse violence on the basis of a victim's identity and require the giving of jury instructions on bias and prejudice upon the request of either the prosecution or defense. ${ }^{430}$ Under the proposed legislation, initially entitled the "Secure a Fair and Equitable Trial Act of 2017," and reintroduced in September 2019 as the "Tony Hunter and Bella Evangelista Panic Defense Prohibition Act," Chapter 1 of Title 23 would be amended with the purpose of:

curtail[ing] the availability and effectiveness of defenses that seek to partially or completely excuse crimes such as murder and assault on the grounds that the victim's sexual orientation, gender identity, or other inherent identity, is to blame for the defendant's violent action and to require an anti-bias jury instruction in criminal trials if requested by the prosecutor or the defendant. ${ }^{431}$

Two new sections, 23-115 and 23-116, would be added to the D.C. Code. Section 23-115, entitled "Limit on defenses that seek to excuse violence on the basis of a victim's identity," would provide that "[f]or any crime of violence, sufficient or adequate provocation for a defense premised on 'heat of passion' shall not exist if the defendant's actions are related to the discovery of, knowledge about, or the potential disclosure of" a number of characteristics or perceived characteristics of the victim. ${ }^{432}$ The bill lists "gender identity or expression" and "sexual orientation" as two of these characteristics. ${ }^{433}$

Section 23-116 would also require the court, upon the request of either the defendant or the government in a criminal proceeding, to instruct the jury not to "let bias, sympathy, prejudice, or public opinion influence your decision."434 "Bias" includes bias against "the victim or victims, witnesses, or defendant based upon his or her disability, sex, national origin, race, color, religion, gender identity or expression, or sexual orientation." 435

The Grosso bill would go further than any of the existing bans by expanding the list of protected categories beyond sexual orientation, gender, gender identity, and gender expression to include disability, national origin, race, color, religion, and sex. One risk of expanding the list of protected categories as broadly as Grosso's bill does is that such extension may dilute the expressive power of the legislation. ${ }^{436}$

430. Legis. Summary, D.C. Council B22-0102, 22d Council, 2017-2018 Sess. (D.C. 2017).

431. Id.

432. Id.

433. Id.

434. Id.

435. Id.

436. See, e.g., Rob Kuznia, In Hate Crimes, Defining "Victim”, WASH. Post., Sept. 11, 2019, at A3 (noting that law professor Kami Chavis "says the continuing expansions [of who is protected under hate crime statutes] run the risk of diluting such statutes' original intention: to protect historically marginalized or persecuted groups"). 
A bill that specifically targets the use of gay and trans panic defense arguments sends a much clearer normative message that it is not okay to kill a gay man or a transgender woman and then use the victim's sexual orientation or gender identity to try to avoid liability for that killing.

In requiring D.C. courts to give an anti-bias jury instruction, the proposed legislation follows California ${ }^{437}$ and Hawaii. ${ }^{438}$ The Grosso bill would thus go further than several of the recently enacted laws, which do not mandate anti-bias jury instructions upon the request of either party.

In September 2019, D.C. Council Chair Phil Mendelson introduced another bill entitled, the "Sexual Orientation and Gender Identity Panic Defense Prohibition Act of 2019," which also attempts to ban gay and trans panic arguments. ${ }^{439}$ Under Mendelson's bill, criminal defendants charged with homicide would be barred from claiming they acted in a heat of passion, in self-defense, or as a result of reduced mental capacity based upon the discovery that the victim was gay or transgender. ${ }^{440}$ More specifically, subsection (a) of the legislation would provide:

For a crime of violence, adequate provocation for a defense premised on "heat of passion" shall not exist if the defendant's actions are related to the discovery of, knowledge about, or potential disclosure of the victim's actual or perceived gender identity or expression, or sexual orientation, including under circumstances in which the victim made an unwanted, non-forcible romantic or sexual advance toward the defendant, or if the defendant and victim dated or had a romantic relationship. ${ }^{441}$

437. While the legislation passed by the California legislature in 2014 does not include a provision mandating anti-bias jury instructions, California passed anti-bias jury legislation in 2006 when it enacted the Gwen Araujo Justice for Victims Act. That Act provides:

(d) It is against public policy for juries to render decisions tainted by bias based upon the victim's actual or perceived disability, gender, nationality, race or ethnicity, religion or sexual orientation, or his or her association with a person or group with one or more of these characteristics.

(e) "Panic strategies" are those strategies that try to explain a defendant's actions or emotional reactions based upon the knowledge or discovery of the fact that the victim possesses one or more of the characteristics listed above or associates with a person or group with one or more of these characteristics.

(f) The Legislature is concerned about the use of societal bias in criminal proceedings and the susceptibility of juries to such bias. The use of so-called "panic strategies" by defendants in criminal trials opens the door for bias against victims based on one or more of the characteristics listed above or an association with a person or group with one or more of those characteristics.

(g) It is against public policy for a defendant to be acquitted of a charged offense or convicted of a lesser included offense based upon an appeal to the societal bias that may be possessed by members of a jury.

Gwen Araujo Justice for Victims Act, CAL. Penal Code $§ 1127 \mathrm{~h}$ (2014).

438. HaW. REV. STAT. § 707-702 (2019).

439. Matt Baume, D.C. Moves to Ban 'Gay Panic' Defense Legal in 42 States, Out (Sept. 18, 2019), https:// www.out.com/news/2019/9/18/DC-Moves-Ban-Gay-Panic-Defense-Legal-States [https://perma.cc/LA8L-WPFD]

440. Id.

441. Sexual Orientation and Gender Identity Panic Defense Prohibition Act of 2019, D.C. Council B23-0409, 23d Council (D.C. 2019). 
Subsection (b) would provide:

A defendant does not suffer from reduced mental capacity based solely on the discovery of, knowledge about, or potential disclosure of the victim's actual or perceived gender identity or expression, or sexual orientation, including under circumstances in which the victim made an unwanted, non-forcible romantic or sexual advance toward the defendant, or if the defendant and victim dated or had a romantic relationship. ${ }^{442}$

Subsection (c) would provide:

A person is not justified in using force against another based solely on the discovery of, knowledge about, or potential disclosure of the victim's actual or perceived gender identity or expression, or sexual orientation, including under circumstances in which the victim made an unwanted, non-forcible romantic or sexual advance toward the defendant, or if the defendant and victim dated or had a romantic relationship. ${ }^{443}$

The Mendelson bill follows Rhode Island, Connecticut, and Maine in barring defendants from claiming that the discovery that the victim was gay or a transgender individual either provoked them into a heat of passion, caused them some mental incapacity, or somehow justified their use of force in self-defense. Like the existing bans, it focuses specifically on prohibiting defendants from arguing that the discovery of the victim's sexual orientation or gender identity was what provoked the defendant into a heat of passion, caused mental incapacity, or justified their use of force in self-defense.

\section{U.S. Congress (pending)}

In July 2018, Senator Edward Markey (D-MA) and Representative Joe Kennedy (D-MA) introduced the Gay and Trans Panic Defense Prohibition Act of 2018. ${ }^{444}$ This legislation would amend Chapter 1 or title 18 of the United States Code, Section 28 , by adding the following provisions to the end of the chapter:

(a) Prohibition. No nonviolent sexual advance or perception or belief, even if inaccurate, of the gender, gender identity or expression, or sexual orientation of an individual may be used to excuse or justify the conduct of an individual or mitigate the severity of an offense.

(b) Past Trauma. Notwithstanding the prohibition in subsection (a), a court may admit evidence, in accordance with the Federal Rules of Evidence, of prior trauma to the defendant for the purpose of excusing or justifying the conduct of the defendant or mitigating the severity of an offense. ${ }^{445}$ 
The proposed federal legislation is well-intentioned. At first glance, it even seems progressive in using the sexual orientation-neutral term "sexual" rather than "homosexual" in referring to a "nonviolent sexual advance." 446 In providing that "[n]o nonviolent sexual advance . . . may be used to excuse or justify the conduct of an individual or mitigate the severity of an offense," 447 however, the federal legislation could have several unintended consequences. For example, it would prohibit a female defendant from arguing that she was provoked into a heat of passion by a man groping her breasts or pinching her buttocks because the man's "non-violent" 448 sexual advance could not be used to excuse the female defendant's conduct or mitigate a murder charge to voluntary manslaughter.

The federal legislation would also prohibit some male defendants from arguing provocation in cases in which many of us would probably want to allow the defendant to argue provocation. Think about the male teenager who was allegedly groped by actor Kevin Spacey at a bar where the teenager worked as a busboy in $2016 .{ }^{449}$ Imagine that the teenager had reacted differently. Instead of trying to shift his body and move Spacey's hands away, ${ }^{450}$ let's say our hypothetical teenage boy had grabbed a sharp knife from the counter and flailed about, trying to stab Spacey to try to avoid the unwanted groping. Imagine further that upon being stabbed in the arm, Spacey fell back, hit his head on the sharp bar counter, and died. Imagine further that this incident occurred at a restaurant bar in a national park, so the federal government had jurisdiction over the case. If our hypothetical teenage boy

\footnotetext{
446. Id.

447. Id.
}

448. Even though the average layperson might think that having one's breasts groped or buttocks pinched constitutes a "violent" sexual advance, the law generally views such actions as "non-violent." See, e.g., United States v. Watts, 798 F.3d 650, 652 (7th Cir. 2015) (describing "groping" a woman or child as "sexually offensive but not violent physical contact"); United States v. Bayes, 210 F.3d 64, 69 (1st Cir. 2000) (noting that "defendant groped a minor in a nonviolent but sexually offensive manner").

449. For details about the actual case, see Man Sues Kevin Spacey Over Alleged Groping Incident at Nantucket Bar, CBS NEws (June 27, 2019), https://www.cbsnews.com/news/kevin-spacey-nantucket-trial-mansues-over-alleged-groping-club-car-nantucket-bar-2019-06-27 [https://perma.cc/QBH6-8AB7]. In July 2019, prosecutors dismissed the criminal charges they had filed against Spacey after his accuser refused to testify about a missing cellphone that Spacey's lawyers claimed had evidence supporting the actor's claim of innocence. See Kevin Spacey: Prosecutors Drop Case Accusing Actor of Groping Teen, GuARDIAN (July 17, 2019), https:// www.theguardian.com/culture/2019/jul/17/kevin-spacey-charges-dropped-sexual-assault-case-groping-teennantucket [https://perma.cc/B9DE-RS72] (noting that the two time Oscar winner was charged with battery and indecent assault in 2018 after a young man alleged that in 2016, when he was a teenager working as a busboy at a bar in Nantucket, Spacey bought him several drinks after his shift and tried to persuade him to come home with him before unzipping the young man's pants and groping him for about three minutes); Joey Garrison \& Maria Puente, Judge: Kevin Spacey Groping Case 'May Well Be Dismissed' As Accuser Pleads the 5th, USA TODAY (July 8, 2019), https://www.usatoday.com/story/entertainment/celebrities/2019/07/08/kevin-spaceyaccuser-appears-groping-hearing-his-missing-cellphone/1671779001 [https://perma.cc/LM2L-9VVG].

450. See Phil Helsel, Man Who Accused Kevin Spacey of Sexual Assault May Have Filmed Alleged Groping, NBC NEwS (Dec. 26, 2018), https://www.nbcnews.com/pop-culture/pop-culture-news/alleged-victim-kevinspacey-sexual-assault-may-have-filmed-groping-n952176 [https://perma.cc/KTC5-9JPK] (noting that "police documents say the alleged victim 'tried to shift away with his body' and move Spacey's hands away, 'but Spacey kept reaching down his pants'”). 
were to be charged with murder in federal court with legislation like the proposed federal legislation, he would be prohibited from using the fact that Spacey had tried to grope him to try to mitigate the charge from murder to manslaughter. ${ }^{451}$

Although reasonable minds might disagree about whether our hypothetical teenage boy reacted reasonably, most of us would agree that he should at least be permitted to make the argument that he was reasonably provoked into a heat of passion. The federal legislation, however, would bar him from even posing such an argument because a nonviolent sexual advance cannot be used to excuse or justify the conduct of a defendant or mitigate the severity of an offense.

The focus should be on prohibiting defendants from trying to excuse or justify their behavior by claiming that discovery of the sexual orientation or gender identity of the victim caused them to behave violently, as is the case with the existing bans. ${ }^{452}$ Instead, the proposed federal legislation bars defendants from arguing that a nonviolent sexual advance provoked the defendant into a heat of passion. While the existing bans include qualifying language such as "including under circumstances in which the victim made an unwanted non-forcible romantic or sexual advance toward the defendant," 453 these bans focus - as they should - on whether the defendant is claiming that his discovery or knowledge about the victim's identity as a transgender person or a gay individual was what provoked him. If the federal legislation were to delete the words "non-violent sexual advance or" and simply state, "No perception or belief, even if inaccurate, of the gender, gender identity or expression, or sexual orientation of an individual may be used to excuse

451. A layperson might wonder whether our hypothetical teenager would have a legitimate claim of selfdefense. A court would probably answer this question in the negative if it found that the teen used deadly force in response to nondeadly force. See Force, BLACK's LAW DiCTIONARY (11th ed. 2019) (defining "deadly force" as "violent action known to create a substantial risk of causing death or serious bodily harm"); 2 SUBST. CRIM. L. § 10.4(a) (3d ed. 2018) (defining "deadly force" as force "which its user uses with the intent to cause death or serious bodily injury to another or . . . which he knows creates a substantial risk of death or serious bodily injury to the other"); Model PENAL CODE $§ 3.11$ (2018) (defining "deadly force" as "force that the actor uses with the purpose of causing or that he knows to create a substantial risk of causing death or serious bodily injury"). The defendant may use deadly force only if he honestly and reasonably believed he was being threatened with deadly force. See 2 SuBST. CRIM. L. § 10.4(b) (3d ed. 2018) (stating that self-defense doctrine "recognizes that the amount of force which [one] may justifiably use must be reasonably related to the threatened harm which [one] seeks to avoid," and explaining that a person may only use deadly force "if he reasonably believes that the other is about to inflict unlawful death or serious bodily harm upon him"); 2 WHARTON's CRIMINAL LAW § 127 (15th ed. 2019) ("A defendant may kill in self-defense when he reasonably believes that he is in imminent danger of losing his life or suffering great bodily harm."); Aya Gruber, Leniency as a Miscarriage of Race and Gender Justice, 76 ALB. L. REV. 1571, 1596 (2013) (noting that self-defense usually "allows the defendant to use deadly force upon reasonable fear of imminent death, serious bodily injury, or a violent felony”); see also Stuart P. Green, Castles and Carjackers: Proportionality and the Use of Deadly Force in Defense of Dwellings and Vehicles, 1999 U. ILl. L. REv. 1, 5 (1999) (describing the idea that "the force used must be proportional to the harm threatened" as a "basic principle of self-defense"). Even if the teen in this hypothetical case could assert a claim of self-defense, he might want to argue provocation in the alternative in case the jury rejects his selfdefense claim.

452. See supra text accompanying notes $355-416$.

453. See supra text accompanying notes 356 (California), 380-381 (Rhode Island), 383-86 (Nevada), 394 (Hawaii), 398-403 (Connecticut), 404-09 (Maine), 410 (New Jersey), 413 (Washington). 
or justify the conduct of an individual or mitigate the severity of an offense," it would better limit a defendant's ability to use the discovery of or knowledge about victim's sexual orientation or gender identity to excuse violent conduct.

\section{Model Legislation}

If a legislature wants to enact legislation curtailing the use of gay and trans panic defense strategies, it has many good examples to follow. Borrowing language from the existing legislative bans, I propose the following model legislation:

1. For the purpose of determining the legal adequacy of an alleged provocation by a defendant charged with a criminal homicide, the alleged provocation or heat of passion shall be deemed not objectively reasonable and not legally adequate if based upon the discovery of, knowledge about, or potential disclosure of the actual or perceived sexual orientation or gender identity or expression of the victim. Nothing in this section shall preclude the jury from considering all relevant facts to determine whether the defendant was in fact provoked for purposes of establishing subjective provocation.

2. The discovery of, knowledge about, or potential disclosure of the actual or perceived sexual orientation or gender identity or expression of the victim may not be used to support a claim that the defendant was suffering from insanity, temporary or otherwise, or diminished capacity.

3. A person is not justified in using physical force against another person based solely upon the discovery of, knowledge about, or potential disclosure of the actual or perceived sexual orientation or gender identity or expression of the victim. ${ }^{454}$

I do not claim to be inventing completely new language with this model legislation. Rather, the model legislation takes the best from each of the existing bans and eliminates the unnecessary or unhelpful. No state has adopted the precise language in this model legislation. In this respect, the model legislation adds value to the existing landscape.

Like most of the existing bans, Section 1 of the model legislation provides that the discovery of or knowledge about the actual or perceived sexual orientation or gender identity or expression of the victim does not constitute legally adequate provocation. It thus would bar most defendants claiming gay panic or trans panic from satisfying the requirements necessary to mitigate a murder charge down to voluntary manslaughter through the provocation defense.

Moreover, like the legislative bans in Rhode Island, Connecticut, and Maine, the model legislation would apply not just to claims of provocation, but also to mental incapacity defenses like temporary insanity and diminished capacity and claims of

454. I include the word "solely" in the third subsection because I think a defendant should be allowed to argue self-defense if the victim did something to make the defendant reasonably believe it was necessary to use deadly force to protect against an imminent threat of death or serious bodily injury. 
self-defense. Sections 2 and 3 make clear that the discovery of or knowledge about another person's actual or perceived sexual orientation or gender identity or expression cannot be the basis for a claim of insanity, diminished capacity, or selfdefense.

Unlike most of the existing legislative bans, the model legislation does not have the "including under circumstances in which the victim made an unwanted nonforcible romantic or sexual advance towards the defendant, or if the defendant and victim dated or had a romantic or sexual relationship" language for two reasons. First, this language is unnecessary. The model legislation, like the existing bans, precludes the defendant from arguing that the discovery, knowledge, or disclosure that the victim was gay or transgender constitutes legally adequate provocation. In other words, a defendant cannot base his provocation argument on the discovery of, knowledge about, or disclosure of the victim's sexual orientation or transgender identity. It is not necessary that the defendant learned of the victim's status as a gay male or transgender female through an unwanted sexual advance. It is also not necessary that the defendant and the victim dated or had a romantic or sexual relationship. The discovery of or knowledge about the victim's status as a sexual minority is just not legally adequate provocation.

Second, the "including under circumstances" language suggests that a defendant would be precluded from arguing that an unwanted nonviolent sexual advance provoked him into a heat of passion when this is not actually the case. None of the existing legislative bans preclude defendants from arguing they were reasonably provoked into a heat of passion by a nonviolent sexual advance by the victim. The only thing the existing bans preclude is the argument that the discovery of, knowledge about, or potential disclosure of the victim's sexual orientation or gender identity or expression constituted objectively reasonable or legally adequate provocation.

As is the case with all of the existing bans, a defendant who is able to show that he was provoked not by the discovery of or knowledge about the victim's heterosexual orientation or transgender identity, but by something the victim said or did, would be allowed to assert the provocation defense. Section 1 of the model legislation, however, would go further than several of the existing bans. It purposely does not include the word "solely" before "based upon the discovery of, knowledge about, or potential disclosure of the actual or perceived sexual orientation or gender identity or expression of the victim" to preclude the defendant from arguing he was provoked both by the discovery that the victim's gender identity did not match her biological sex and by something else the victim said or did. If even part of the defendant's argument is that the discovery that the victim was a transgender woman provoked him, the model legislation would bar him from asserting a provocation defense. If the word "solely" were inserted after the word "if" and before the words "based upon" in Section 1, this would allow a defendant to come up with some other reason besides the discovery that his victim was a trans woman in order to escape the legislative ban. By including the word "solely" in their bans, Rhode 
Island, Connecticut, and Maine provide weaker protection to gay and transgender victims than the model legislation. ${ }^{455}$

The model legislation, however, does include the word "solely" in Section 3, providing that "[a] person is not justified in using physical force against another person based solely upon the discovery of, knowledge about, or potential disclosure of the actual or perceived sexual orientation or gender identity or expression of the victim." If the victim did something to make the defendant reasonably believe it was necessary to use deadly force to protect against an imminent threat of death or serious bodily injury, the defendant should be allowed to argue selfdefense. Under such circumstances, the model legislation would allow the defendant to assert a claim of self-defense even if the defendant were also to claim that the discovery of or knowledge about the victim's sexual orientation or transgender status somehow also supported his claim of self-defense.

\section{CONCLUSION}

Violence against the transgender community is a serious problem today. When a man kills a transgender woman and claims that his discovery that the victim was biologically male was so upsetting to him that it provoked him into a heat of passion, his trans panic argument should be rejected. Educating the jury about the stereotypes that make a trans panic argument persuasive is a necessary first step towards encouraging the jury to reject the trans panic defense, but education alone is not sufficient. A legislative ban on the trans panic defense is a better way to ensure that jurors reject the argument that it is objectively reasonable for a man who discovers that his romantic interest is a transgender woman to respond with physical violence.

\footnotetext{
455. Section 2 of the model legislation, which covers mental defect defenses, also omits the word "solely," whereas Rhode Island, Connecticut, and Maine include the word "solely" in their sections on mental defect defenses. Rhode Island, for example, provides that "[a] defendant does not suffer from reduced mental capacity based solely on the discovery of, or knowledge about, or potential disclosure of the victim's actual or perceived gender, gender identity, gender expression, or sexual orientation[.]" 12 R.I. GEN. LAws § 12-17-18 (2019) (emphasis added). Similarly, Connecticut provides, "No defendant may claim as a defense under this section that such mental disease or defect was based solely on the discovery of, knowledge about or potential disclosure of the victim's actual or perceived sex, sexual orientation or gender identity or expression[.]" CONN. GEN. STAT. $\S 53 \mathrm{a}-13$ (b)(2) (2019) (emphasis added). Maine, too, provides, "An actor does not suffer from an abnormal condition of the mind based solely on the discovery of, knowledge about or potential disclosure of the victim's actual or perceived gender, gender identity, gender expression or sexual orientation[.]" ME. STAT. tit. 17-A, § 38 (2019) (emphasis added). The model legislation omits the word "solely" in Section 2 for the same reason it omits the word "solely" in Section 1. This omission precludes a defendant from coming up with some other reason to explain his mental disease or defect and thus being able to also use the discovery that the victim was a trans woman or gay man to support his mental defect defense.
} 


\section{APPENDIX}

\begin{tabular}{|c|c|c|}
\hline State & $\begin{array}{c}\text { Portion of Hate Crime Statute Relating } \\
\text { to Gender Identity }\end{array}$ & Statutory Provision \\
\hline California $^{456}$ & $\begin{array}{l}\text { defining a hate crime as one "committed, in } \\
\text { whole or in part, because of one or more of } \\
\text { the following actual or perceived charac- } \\
\text { teristics of the victim: (1) Disability, (2) } \\
\text { Gender, (3) Nationality, (4) Race or ethnic- } \\
\text { ity, (5) Religion, (6) Sexual orientation, (7) } \\
\text { Association with a person or group with } \\
\text { one or more of these actual or perceived } \\
\text { characteristics." (emphasis added) }\end{array}$ & $\begin{array}{l}\text { CAL. PENAL CODE } \\
\S 422.55(a)(2019)\end{array}$ \\
\hline Colorado & $\begin{array}{l}\text { defining bias motivated crimes as those in } \\
\text { which the defendant acts "with the intent to } \\
\text { intimidate or harass another person because } \\
\text { of that person's actual or perceived race, } \\
\text { color, religion, ancestry, national origin, } \\
\text { physical or mental disability, or sexual ori- } \\
\text { entation" and defining "sexual orientation" } \\
\text { as "a person's actual or perceived orienta- } \\
\text { tion toward heterosexuality, homosexual- } \\
\text { ity, bisexuality, or transgender status." } \\
\text { (emphasis added) }\end{array}$ & $\begin{array}{l}\text { COLO. REV. STAT. } \\
\S \S 18-9-121(2) \&(5) \\
\text { (b) }(2019)\end{array}$ \\
\hline Connecticut & $\begin{array}{l}\text { providing that "[i]t shall be a discrimina- } \\
\text { tory practice in violation of this section for } \\
\text { any person to subject ... any other person } \\
\text { to the deprivation of any rights, privileges } \\
\text { or immunities, secured or protected by the } \\
\text { Constitution or laws of this State or of the } \\
\text { United States, on account of religion, } \\
\text { national origin, alienage, color, race, sex, } \\
\text { gender identity or expression, sexual orien- } \\
\text { tation, blindness, mental disability, physi- } \\
\text { cal disability or status as a veteran." } \\
\text { (emphasis added) }\end{array}$ & $\begin{array}{l}\text { CONN. GEN. STAT. } \\
\S 46 a-58 \text { (a) (2019) }\end{array}$ \\
\hline
\end{tabular}

456. California defines gender as "sex, [which] includes a person's gender identity and gender expression. 'Gender expression' means a person's gender-related appearance and behavior whether or not stereotypically associated with the person's assigned sex at birth.” CAL. PENAL CODE $§ 422.56$ (c) (2019). 


\section{Continued}

\begin{tabular}{|c|c|c|}
\hline State & $\begin{array}{c}\text { Portion of Hate Crime Statute Relating } \\
\text { to Gender Identity }\end{array}$ & Statutory Provision \\
\hline Delaware & $\begin{array}{l}\text { providing for enhanced penalties when a de- } \\
\text { fendant intentionally "[s]elects the victim } \\
\text { because of the victim's race, religion, color, } \\
\text { disability, sexual orientation, gender identity, } \\
\text { national origin or ancestry." (emphasis added) }\end{array}$ & $\begin{array}{l}\text { DEL. CODE ANN. tit. } 11 \\
\S 1304 \text { (a)(2) (2019) }\end{array}$ \\
\hline $\begin{array}{l}\text { District of } \\
\text { Columbia }\end{array}$ & $\begin{array}{l}\text { noting that a “'[b]ias-related crime' means a } \\
\text { designated act that demonstrates an accused's } \\
\text { prejudice based on the actual or perceived } \\
\text { race, color, religion, national origin, sex, age, } \\
\text { marital status, personal appearance, sexual } \\
\text { orientation, gender identity or expression, } \\
\text { family responsibility, homelessness, physical } \\
\text { disability, matriculation, or political affilia- } \\
\text { tion of a victim.” (emphasis added) }\end{array}$ & $\begin{array}{l}\text { D.C. CODE } \S 22-3701 \\
\text { (1) }(2019)\end{array}$ \\
\hline Hawaii & $\begin{array}{l}\text { defining a hate crime as "any criminal act } \\
\text { in which the perpetrator intentionally } \\
\text { selected a victim, or in the case of a prop- } \\
\text { erty crime, the property that was the object } \\
\text { of a crime, because of hostility toward the } \\
\text { actual or perceived race, religion, disabil- } \\
\text { ity, ethnicity, national origin, gender iden- } \\
\text { tity or expression, or sexual orientation of } \\
\text { any person." (emphasis added) }\end{array}$ & $\begin{array}{l}\text { HAW. REV. STAT. } \\
\S 846-51(2019)\end{array}$ \\
\hline Illinois $^{457}$ & $\begin{array}{l}\text { providing that a person commits a hate } \\
\text { crime if "by reason of the actual } \text { or per- } \\
\text { ceived race, color, creed, religion, ancestry, } \\
\text { gender, sexual orientation, physical or } \\
\text { mental disability, or national origin of } \\
\text { another individual or group of individuals . } \\
\text {. he or she commits assault, battery, intim- } \\
\text { idation, stalking." (emphasis added) }\end{array}$ & $\begin{array}{l}720 \text { ILL. COMP. STAT. } \\
\S 5 / 12-7.1 \text { (a) (2019) }\end{array}$ \\
\hline
\end{tabular}

457. While Illinois does not explicitly state that the words "perceived . . gender" in its hate crime statute would protect transgender individuals, there is case law in Illinois that could be used to support such an interpretation. See In re B.C., 680 N.E.2d 1355, 1360-61 (Ill. 1997) (applying the hate crime enhancement in a case where the victim was not an African American or perceived by the defendant to be an African American on the ground that the "primary focus of the [hate crime] statute was intended to be directed towards the biased motivation of the perpetrator, rather than towards the status of the victim" and "the victim of a hate crime need not be a member of one of the statute's enumerated classes providing reason for the offense"). 


\section{Continued}

\begin{tabular}{|l|l|l|}
\hline \multicolumn{1}{|c|}{ State } & \multicolumn{1}{|c|}{$\begin{array}{c}\text { Portion of Hate Crime Statute Relating } \\
\text { to Gender Identity }\end{array}$} & \multicolumn{1}{|c|}{ Statutory Provision } \\
\hline Louisiana 458 & $\begin{array}{l}\text { making it unlawful to "select the victim of } \\
\text { [certain] offenses against person and prop- } \\
\text { erty because of actual or perceived race, } \\
\text { age, gender, religion, color, creed, disabil- } \\
\text { ity, sexual orientation, national origin, or } \\
\text { ancestry of that person." (emphasis added) }\end{array}$ & $\begin{array}{l}\text { LA. REV. STAT. ANN. } \\
\S 14: 107.2 \text { (A) (2019) }\end{array}$ \\
\hline Maryland & $\begin{array}{l}\text { including in its hate crime statute "sexual } \\
\text { orientation" defined as "the identification } \\
\text { of an individual as to male or female homo- } \\
\text { sexuality, heterosexuality, bisexuality, or } \\
\text { gender-related identity." (emphasis added) }\end{array}$ & $\begin{array}{l}\text { MD. CODE ANN., } \\
\text { CRIM. LAW § 10-301 } \\
\text { (c) (2019) }\end{array}$ \\
\hline Massachusetts & $\begin{array}{l}\text { making it a crime to "commi[t] an assault } \\
\text { or a battery upon a person or damage[] the } \\
\text { real or personal property of a person with } \\
\text { the intent to intimidate such person because } \\
\text { of such person's race, color, religion, } \\
\text { national origin, sexual orientation, gender } \\
\text { identity, or disability." (emphasis added) }\end{array}$ & $\begin{array}{l}\text { MASS. GEN. LAWS ch. } \\
\text { 265 § 39 (2019) }\end{array}$ \\
\hline
\end{tabular}

458. Louisiana does not state that the words "perceived . . . gender" in its hate crime statute provides protection to transgender individuals who are perceived by their assailants to be of a different sex than their chosen gender identity, and it does not appear that there are any Louisiana cases interpreting this language to date. The question whether the Louisiana hate crime statute covers transgender individuals became pertinent in March 2017, when two transgender women, Chyna Gibson and Ciara McElveen, were killed in apparently unrelated incidents within a three-day period in New Orleans. Initially, the police suggested that if the women were killed because of their transgender identity, they would proceed as if these homicides were hate crimes. See Julia O'Donoghue, Do Louisiana Hate Crime Laws Cover Transgender People?, NOLA.COM (Mar. 4, 2017), https://www.nola.com/news/politics/article_23b5ab06-ff2c-5146-bbf3-383f5f86fc96.html [https://perma.cc/ R6J8-X6VU]. Upon further investigation, however, police were unable to find evidence that the women were targeted because of their status as transgender women. Emily Lane, In Recent Murders of Transgender Women, No Evidence of Hate Crimes: NOPD, NOLA.COM (Mar. 2, 2017), https://www.nola.com/news/crime_police/ article 1ba2d3d9-a9a2-5f1b-b82f-01f4e398c756.html [https://perma.cc/M69P-VF39]. It thus remains an open question whether Louisiana's hate crime statute covers transgender victims. 


\section{Continued}

\begin{tabular}{|c|c|c|}
\hline State & $\begin{array}{c}\text { Portion of Hate Crime Statute Relating } \\
\text { to Gender Identity }\end{array}$ & Statutory Provision \\
\hline Minnesota $^{459}$ & $\begin{array}{l}\text { providing that "[w]hoever assaults another } \\
\text { because of the victim's ... actual or per- } \\
\text { ceived race, color, religion, sex, sexual ori- } \\
\text { entation, disability..., age, or national } \\
\text { origin may be sentenced to imprisonment } \\
\text { for not more than one year or to payment of } \\
\text { a fine of not more than } \$ 3,000 \text { or both." } \\
\text { (emphasis added) }\end{array}$ & $\begin{array}{l}\text { MinN. STAT. } \\
\S 609.2231(4)(a) \\
(2019)\end{array}$ \\
\hline Mississippi ${ }^{460}$ & $\begin{array}{l}\text { providing that "[i]n order to impose an } \\
\text { enhanced penalty under the provisions of } \\
\text { Sections 99-19-301 through 99-19-307, the } \\
\text { jury must find beyond a reasonable doubt: } \\
\text { (a) That the defendant perceived, knew, or } \\
\text { had reasonable grounds to know or per- } \\
\text { ceive that the victim was within the class } \\
\text { delineated; and (b) That the defendant } \\
\text { maliciously and with specific intent com- } \\
\text { mitted the offense because the victim was } \\
\text { within the class delineated" and "(3) That } \\
\text { the victim was within the class delineated } \\
\text { means that the reason the underlying crime } \\
\text { was committed was the victim's actual or } \\
\text { perceived race, color, religion, ethnicity, } \\
\text { ancestry, national origin or gender." (em- } \\
\text { phasis added) }\end{array}$ & $\begin{array}{l}\text { Miss. CoDE ANN. } \\
\S \S 99-19-305(2),(3) \\
(2019)\end{array}$ \\
\hline
\end{tabular}

459. The Human Rights Campaign has argued that Minnesota's hate crime statute covers transgender individuals, pointing to language in another part of the Code. See Minnesota Hate Crimes Law, HuMAN RIGHTS CAMPAIGN, https://web.archive.org/web/20110524081415/http://www.hrc.org/1068.htm [https://perma.cc/ EZX9-BYYW]; see also MINN. STAT. ANN. § 363A.03(44) (2019) (defining "sexual orientation" as including, "having or being perceived as having a self-image or identity not traditionally associated with one's biological maleness or femaleness").

460. It is unclear whether Mississippi's hate crime statute covers transgender individuals. Arguably the inclusion of "perceived ... gender" means the statute provides protection for transgender individuals who are perceived by the defendant to be a different sex or gender than their chosen gender identity, but in February 2019, Mississippi lawmakers introduced Senate Bill 2163, which sought to add "sexual orientation, gender identity, or disability" to Section 99-19-305, Mississippi's hate crime statute. See S.B. 2163, 2019 Leg., Reg. Sess. (Miss. 2019). This bill died in committee, suggesting that lawmakers did not intend to protect gays and lesbians, transgender individuals, or disabled individuals in its hate crime statute. 


\section{Continued}

\begin{tabular}{|c|c|c|}
\hline State & $\begin{array}{l}\text { Portion of Hate Crime Statute Relating } \\
\text { to Gender Identity }\end{array}$ & Statutory Provision \\
\hline Nevada & $\begin{array}{l}\text { providing enhanced penalties for certain } \\
\text { crimes committed "because the actual or } \\
\text { perceived race, color, religion, national ori- } \\
\text { gin, physical or mental disability, sexual ori- } \\
\text { entation or gender identity or expression of } \\
\text { the victim was different from that character- } \\
\text { istic of the perpetrator." (emphasis added) }\end{array}$ & $\begin{array}{l}\text { NEV. REV. STAT. } \\
\S 193.1675(1)(2019)\end{array}$ \\
\hline $\begin{array}{l}\text { New } \\
\text { Hampshire }\end{array}$ & $\begin{array}{l}\text { expanding the law against discrimination } \\
\text { based on gender identity to crimes where the } \\
\text { defendant "[w]as substantially motivated to } \\
\text { commit the crime because of hostility } \\
\text { towards the victim's religion, race, creed, } \\
\text { sexual orientation as defined in RSA } 21: 49 \text {, } \\
\text { national origin, sex, or gender identity as } \\
\text { defined in RSA } 21: 53 . " \text { (emphasis added) }\end{array}$ & $\begin{array}{l}\text { N.H. REV. STAT. ANN. } \\
\S 651: 6(\mathrm{I})(\mathrm{f})(2019)\end{array}$ \\
\hline New Jersey & $\begin{array}{l}\text { providing that "[a] person is guilty of the crime } \\
\text { of bias intimidation if he commits, attempts to } \\
\text { commit, conspires with another to commit, or } \\
\text { threatens the immediate commission of an } \\
\text { offense specified in chapters } 11 \text { through } 18 \text { of } \\
\text { Title } 2 C \text { of the New Jersey statutes ... (1) } \\
\text { with a purpose to intimidate an individual or } \\
\text { group of individuals because of race, color, re- } \\
\text { ligion, gender, disability, sexual orientation, } \\
\text { gender identity or expression, national origin, } \\
\text { or ethnicity." (emphasis added) }\end{array}$ & $\begin{array}{l}\text { N.J. REV. STAT. } \\
\S 2 \text { C:16-1(a) (2019) }\end{array}$ \\
\hline New Mexico & $\begin{array}{l}\text { providing enhanced penalties for crimes com- } \\
\text { mitted "because of the victim's actual or per- } \\
\text { ceived race, religion, color, national origin, } \\
\text { ancestry, age, disability, gender, sexual orien- } \\
\text { tation or gender identity." (emphasis added) }\end{array}$ & $\begin{array}{l}\text { N.M. STAT. ANN. } \\
\S 31-18 B-3 \text { (2019) }\end{array}$ \\
\hline New York & $\begin{array}{l}\text { defining a hate crime as the commission of } \\
\text { certain crimes when the defendant "inten- } \\
\text { tionally selects the person against whom the } \\
\text { offense is committed or intended to be com- } \\
\text { mitted in whole or in substantial part } \\
\text { because of a belief or perception regarding } \\
\text { the race, color, national origin, ancestry, } \\
\text { gender, gender identity or expression, reli- } \\
\text { gion, religious practice, age, disability or }\end{array}$ & $\begin{array}{l}\text { N.Y. PENAL LAW } \\
\S 485.05(1)(\mathrm{a})(2019)\end{array}$ \\
\hline
\end{tabular}




\section{Continued}

\begin{tabular}{|c|c|c|}
\hline State & $\begin{array}{c}\text { Portion of Hate Crime Statute Relating } \\
\text { to Gender Identity }\end{array}$ & Statutory Provision \\
\hline & $\begin{array}{l}\text { sexual orientation of a person, regardless of } \\
\text { whether the belief or perception is correct." } \\
\text { (emphasis added) }\end{array}$ & \\
\hline Oregon & $\begin{array}{l}\text { providing that "[a] person commits a bias } \\
\text { crime in the second-degree if the person ... } \\
\text { (b) intentionally subjects another person to } \\
\text { offensive physical contact because of the } \\
\text { person's perception of the other person's } \\
\text { race, color, religion, gender identity, sexual } \\
\text { orientation, disability or national origin." } \\
\text { (emphasis added) }\end{array}$ & $\begin{array}{l}\text { OR. REV. STAT. } \\
\S 166.155(1)(\mathrm{b})(2019)\end{array}$ \\
\hline $\begin{array}{l}\text { Rhode } \\
\text { Island }^{461}\end{array}$ & $\begin{array}{l}\text { providing for enhanced penalties when a } \\
\text { defendant "intentionally selected the per- } \\
\text { son against whom the offense is committed } \\
\text {... because of the actor's hatred or animus } \\
\text { toward the actual or perceived disability, } \\
\text { religion, color, race, national origin or } \\
\text { ancestry, sexual orientation, or gender of } \\
\text { that person." (emphasis added) }\end{array}$ & $\begin{array}{l}12 \text { R.I. GEN. LAWS } \\
\S 12-19-38(a)(2019)\end{array}$ \\
\hline
\end{tabular}

461. It is unclear whether Rhode Island's use of "perceived . . gender" language in its hate crime statute protects transgender individuals. In 2012, the Rhode Island governor signed the Transgender Hate Crimes Monitoring Bill into law, which defines a "hate crime" as "any crime motivated by bigotry and bias, including, but not limited to threatened, attempted, or completed acts that appear after investigation to have been motivated by . . . sexual orientation, gender, [or] gender identity or expression[.]" 42 R.I. GEN. LAws § 42-28-46 (2019) (emphasis added). Under another provision:

"Gender identity or expression" includes a person's actual or perceived gender, as well as a person's gender identity, gender- related self image, gender-related appearance, or gender-related expression, whether or not that gender identity, gender-related self image, gender-related appearance, or gender-related expression is different from that traditionally associated with the person's sex at birth.

11 R.I. GEN. LAWS ANN. § 11-24-2.1(i) (2009). Section 42-28-46 does not enhance penalties for those who commit hate crimes, but imposes on police additional monitoring and reporting requirements for incident reports involving hate crimes. See id. § 42-28-46. Until Rhode Island revises its hate crime statute to include "gender identity or expression" language, defendants can argue that the hate crime statute does not protect transgender individuals since the Rhode Island legislature could have but did not explicitly provide such protection for transgender individuals as it did in its Transgender Hate Crimes Monitoring Bill. 


\section{Continued}

\begin{tabular}{|c|c|c|}
\hline State & $\begin{array}{c}\text { Portion of Hate Crime Statute Relating } \\
\text { to Gender Identity }\end{array}$ & Statutory Provision \\
\hline Tennessee ${ }^{462}$ & $\begin{array}{l}\text { providing enhanced penalties if " }[\mathrm{t}] \text { he de- } \\
\text { fendant intentionally selected the person } \\
\text { against whom the crime was committed ... } \\
\text { in whole or in part, because of the defend- } \\
\text { ant's belief or perception regarding the } \\
\text { race, religion, color, disability, sexual ori- } \\
\text { entation, national origin, ancestry or gen- } \\
\text { der of that person or the owner or occupant } \\
\text { of that property." (emphasis added) }\end{array}$ & $\begin{array}{l}\text { TENN. CODE ANN. } \\
\S 40-35-114(17) \\
(2019)\end{array}$ \\
\hline Vermont & $\begin{array}{l}\text { providing enhanced penalties for "[a] per- } \\
\text { son who commits, causes to be committed, } \\
\text { or attempts to commit any crime and whose } \\
\text { conduct is maliciously motivated by the } \\
\text { victim's actual or perceived race, color, re- } \\
\text { ligion, national origin, sex, ancestry, age, } \\
\text { service in the U.S. Armed Forces, dis- } \\
\text { ability..., sexual orientation, or gender } \\
\text { identity." (emphasis added) }\end{array}$ & $\begin{array}{l}\text { VT. STAT. ANN. tit } 13 \S \\
1455 \text { (2019) }\end{array}$ \\
\hline Washington & $\begin{array}{l}\text { providing that "[a] person is guilty of a hate } \\
\text { crime offense if he or she maliciously and } \\
\text { intentionally commits one of the following } \\
\text { acts because of his or her perception of the } \\
\text { victim's race, color, religion, ancestry, } \\
\text { national origin, gender, sexual orientation, } \\
\text { gender expression or identity, or mental, phys- } \\
\text { ical, or sensory disability." (emphasis added) }\end{array}$ & $\begin{array}{l}\text { WASH. REV. CODE } \\
\S 9 A .36 .080(1)(2019)\end{array}$ \\
\hline
\end{tabular}

462. Even though the Tennessee hate crime statute does not explicitly state that it protects transgender individuals, on February 8, 2019, Tennessee Attorney General Herbert Slattery issued an opinion expressly stating, "A defendant who targets a person for a crime because that person is transgender has targeted the person because of his or her gender within the meaning of § 40-35-114(17)." Herbert Slattery, Tenn. Att'y Gen., Op. No. 19-01, Sentence Enhancement for Hate Crimes Against Transgender Individuals (Feb. 8, 2019), https://www.tn. gov/content/dam/tn/attorneygeneral/documents/ops/2019/op19-01.pdf. 
Pennsylvania is not included in the Appendix, which lists the jurisdictions with hate crime statutes that include gender identity, because Pennsylvania no longer includes gender identity in its hate crime statute. In 2002, the Pennsylvania legislature initially amended their hate crime statute to include gender identity. ${ }^{463}$ In 2007 , however, a Pennsylvania court ruled that this amendment was unconstitutional. ${ }^{464}$ As of the time of this writing, two bills attempting to amend the ethnic intimidation statute to include gender identity were pending before the Pennsylvania legislature. ${ }^{465}$

463. The amended provision provided the following:

A person commits the offense of ethnic intimidation if, with malicious intention toward the actual or perceived race, color, religion, or national origin, ancestry, mental or physical disability, sexual orientation, gender or gender identity of another individual or group of individuals, he commits an offense under any other provision of this article[.]

See Marcavage v. Rendell, 936 A.2d 188, 190 n.3 (Pa. Cmwlth. 2007) (quoting amended 18 PA. C.S.A. § 2710(a) (emphasis added)).

464. Marcavage, 936 A.2d at 193-94 (holding that the enactment of the act amending the ethnic intimidation statute to include intimidation of persons based on ancestry, mental or physical disability, sexual orientation, gender or gender identity violated the state constitution's prohibition against alteration or amendment that changes the original purpose of the bill).

465. See 2019 PA. H.B. 635; 2019 PA S.B. 96. 